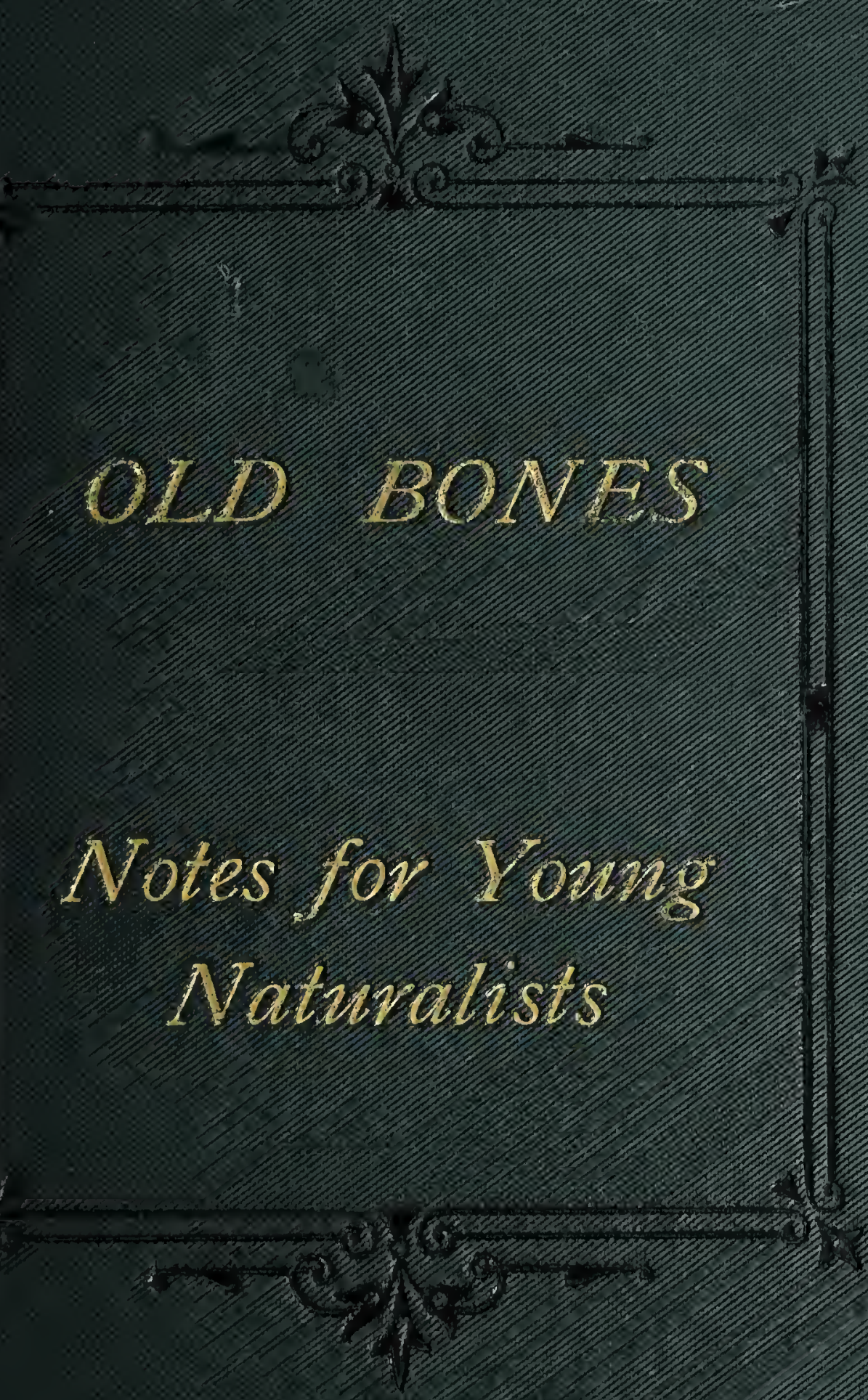




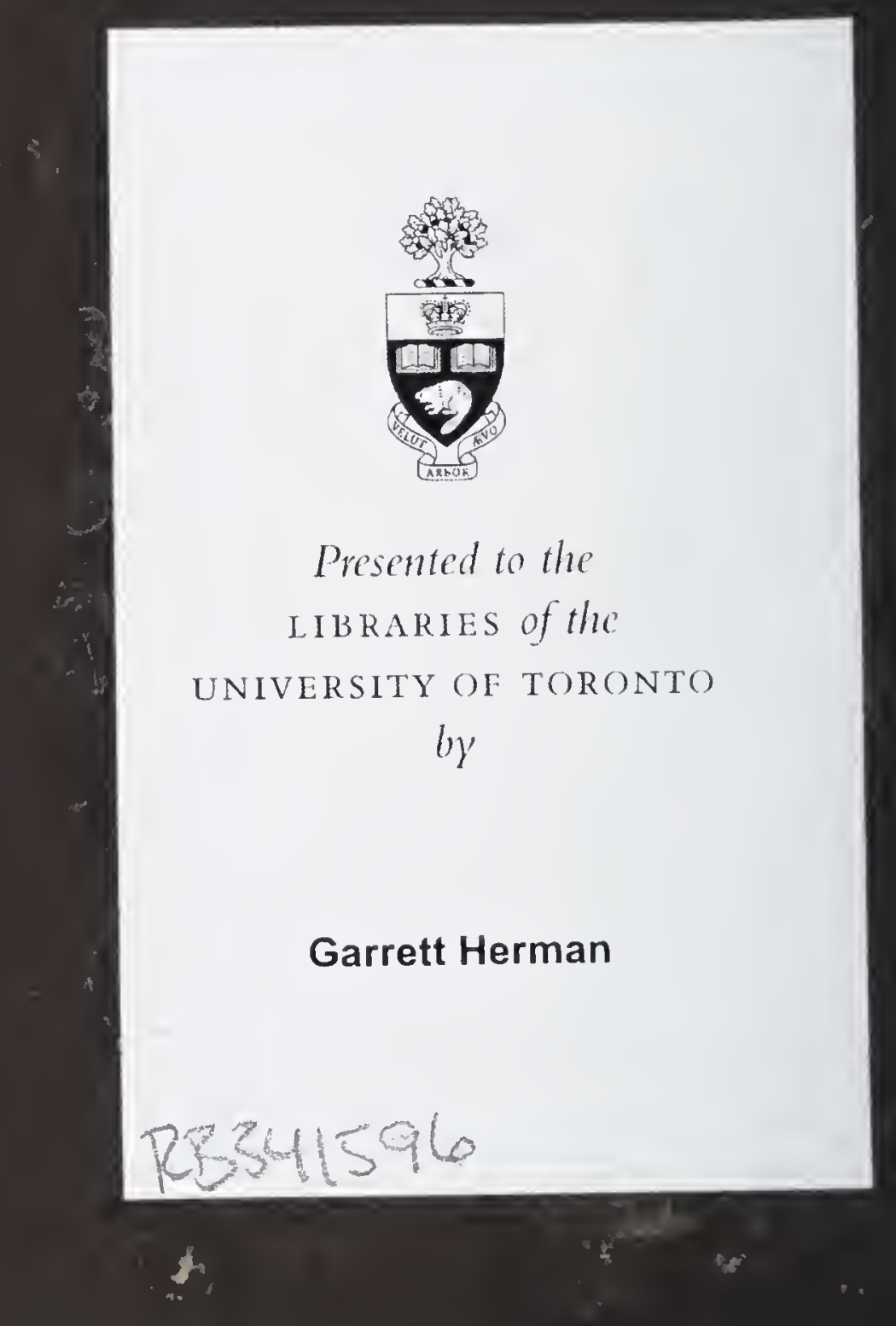





$$
\frac{x^{2}}{5 y} \text {. }
$$

1.

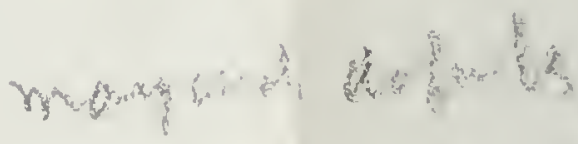
1 and bar 
What hwo hang

OL D B $0 N E S$. 
Digitized by the Internet Archive in 2019 with funding from University of Toronto 
PRE-HISTORIC

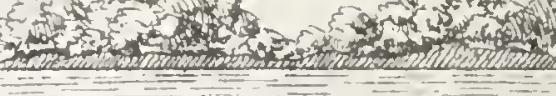
$0 \%$ Glacial drith

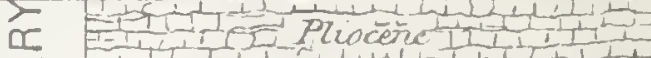

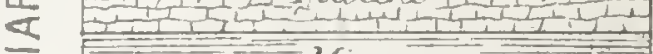

- Niocere

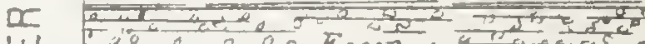

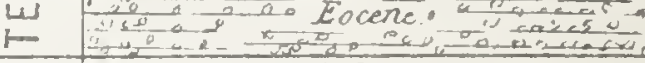

< 000000000000000000

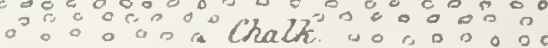
Voper Gneensanat $\succ \quad$ Loner Grensand or Wentaten = =

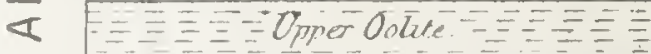

2

2

U

U

u

TRIAS

PERMIAN.

CARBONIFEROUS:

DEVONIAN

$j$
-
$N$
0

SILURIANKL

$-1$

$<$

n. Th

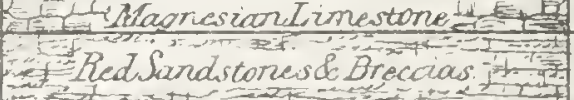

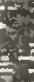
$\because-2$ Coal Deâsures $\Rightarrow$. MillstoreGrit.

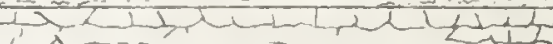
Idlow Sandstoners it

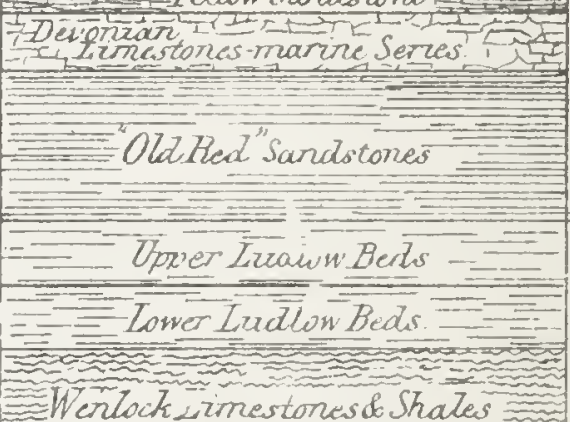

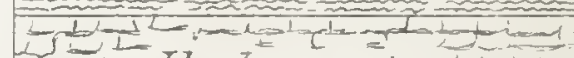
- Ilandivery series L L I

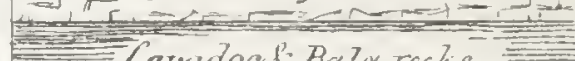
CCarudood' Balurocks.

\begin{tabular}{|c|c|}
\hline$=$ & $M 22 d, 0$ lite \\
\hline & Low Oolite. \\
\hline & $\Rightarrow$ Lras \\
\hline$\Longrightarrow$ & $\begin{array}{l}\text { Kaiper Sandstone } \\
\text { Muschelkalk } \\
\text { Eunter Sandotone }\end{array}$ \\
\hline
\end{tabular}

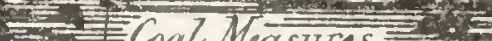
IT-Mountaintrinastone. II TI MAMMALIA. (EXISTING CENERA.) MAMMALIA AND BIROS. FISH. (CTENOIO, CYCLOIO) BIRDS. DINOSAURIA. MAMMALIA.

MARSUPIALIA.

FISH. (HOMOCERCAL .) PTEROSAURIA.

MAMMALIA. (Thaces of a small) Marsunial.

LIZARD REPTILES.

FISH. (HETERO CERCAL) BATRACHIAN REPTILES.

INSECTS.

FISH ANOIOS.)

FIRST LAND PLANTS.

FSH.(HETEROCERCAL.) Frusterace of.

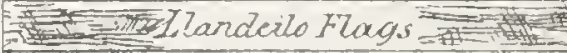

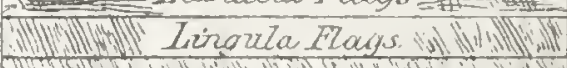

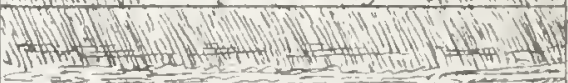

CEPHALOPODA BFA L MIOPODA

INVERTEBRATE ANIMALS CRUSTACEAN. IVIOLUSCAN. ANNELIDAN ZOOPHYTIC. 


\title{
OLD BONES;
}

OR,

\section{NOTES FOR YOUNG NATURALISTS,}

\author{
ON
}

VERTEBRATE ANIMALS, THEIR FOSSIL PREDECESSORS AND ALLIES.

THE REV. W. S. SYMONDS, F.G.S.

RECTOR OF PENDOCK, AUTHOR OF "OLD STONES," "STONES OF THE VALLEY," ETC. ETC.

Sccond Conition, Hyoroughly Zicoiscy.

\section{O NDON :}

ROBERT HARDWICKE, 192, PICCADILLY. 



\section{SIR CHARLES HASTINGS, M.D.}

PRESIDENT OF THE NATURAL HISTORY SOCIETT OF WORCESTER.

\section{Mt dear Sir Charles,}

THis little Work is prepared from a series of notes made when engaged in the study of the Vertebrata and their fossil allies; and a considerable portion of the first chapter was given in an address delivered at the request of yourself and the Council of the Natural History Society of Worcester.

I publish it in the hope that it may prove useful to the Student, when he has the opportunity of visiting any of our various Museums or Zoological Gardens, as I believe that the knowledge acquired from books becomes far more practical when impressed upon the mind by a careful examination of the works of Nature.

The kind sympathy with which you are ever ready to cheer the Naturalist in search of truth, encourages me to dedicate to you the following pages. I would also express my gratitude to several distinguished Naturalists who assisted me in carrying the first edition through the Press, and I have, especially, to thank my friend, Dr. Lankester, for his valuable suggestions, and a separate chapter on the structure of Bones prepared for this edition.

I remain,

Yours ever faithfully,

W. S. SYMONDS. 



\section{CONTENTS.}

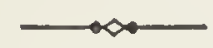

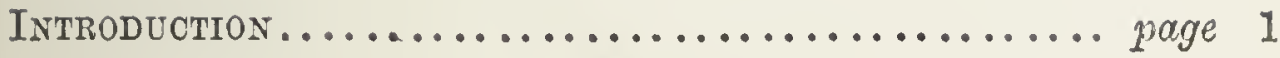

CHAPTER I.

Class I. - Animals that suchle their Yodng ....

CHAPTER II.

ClasS II.-BIRdS ...................... 54

CHAPTER III.

Cliss III.-Reptiles ......................

CHAPTER IV.

Class IV.-Fishes......................... 101

CHAPTER V.

On the Structure of Bone.................. 126

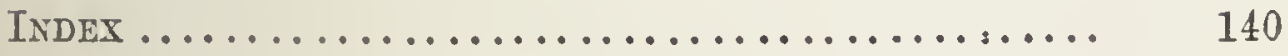





\section{OLD BONES.}

IT has been eloquently and truly said, that everything in Nature is engaged in writing its own history: "the planet and the pebble are attended by their shadows, the rolling rock leares its furrows on the mountain side, the river its channel in the soil, the animal its bones in the stratum; the fern and leaf inscribe their modest epitaphs on the coal, and the falling drop sculptures its story on the sand and on the stone;" yet it must not be imagined that the revelations of that history will be dirulged to those who seek them not, for Nature's truths are "whispered rather than outspoken."

Many persons, in a scientific age, would become scientific without the labour of study, and imagine that knowledge may be acquired by some popular, but ideal method, requiring no more mental fatigue or patient research than reading a novel or perusing a love ditty. Ladies would fain study chemistry as they sigh over the last new novel; while the "sworn horse-courser" wonders that the marvels of astronomy are not so much adapted to his capacity for knowledge as are the lucubrations of the Racing Calendar, or that the perigee is more intricate than the pedigree of an "Echipse."

"There are men, beliering themselves educated, who "occupy themselves with trivialities, and are indifferent to the grandest phenomena-care not to understand the architecture of the heavens, but are deeply interested in some contemptible controversy about the intrigues of Mary Queen of Scots-are learnedly critical over a 
Greek ode, and pass by without a glance that grand epic written by the finger of God upon the strata of the earth!" While others, possessing very limited means and opportunities of studying God's works, nevertheless, as far as those means allow, do study them, and find a great increase of happiness arising from the pursuit of such knowledge, and of the gifts that Nature has in store for the humblest of her disciples.

In these pages I shall endeavour to explain how any person, wishing to become acquainted with the leading principles of Natural History, may, by pursuing the study with system and method, proceed from one subject to the other without falling into the maze of intricacy which generally besets those who commence such investigations without method, and who are altogether ignorant of the first elements that constitute a single branch of that far-spreading tree whose roots are planted in the depths of remotest time, and whose upper boughs are ever growing upwards and onwards to the remotest future.

I have had personal experience of the necessity of beginning at the right end. Many years ago I commenced the study of fossil shells and plants, without the slightest knowledge of the history of the animals that inhabit recent shells, or of the physiology of living plants, and, as a natural consequence, I became confused with terms and definitions of which I knew nothing, and, like the youth who is crammed with Virgil before he has mastered the Latin grammar, had to endure the mortifying discovery, that after months of study I was still an utter ignoramus.

"Natura non facit saltum" is an old adage, and its truth is now being realized throughout the whole history of the animal and vegetable kingdom, past and present; from the creation of the oldest known Cambrian fossil to the creation of spiritual and intellectual man.

The contemplation of the animal kingdom reveals a wondrous unity of plan and of structure; and, notwithstanding the vast numbers of animals that now 
exist on this planet, me learn that all have been constructed upon a few original types.

\section{PRIMARY DIVISIONS.}

The animal kingdom mas divided by the celebrated Cuvier into four sub-kingdoms-Verternata, Motitsca, Articulata, Radita. Recent naturalists, however, have separated certain organisms, called ProTOzOA, from the Radiata, and thus have erected five sub-kingdoms, which are arranged as follows :-

1. Tertebrata. - Animals that have a backbone and internal slieleton; as man, birds, reptiles, fish.

2. Mollusca. - Soft-bodied animals; at the head of which are ranked the nautilus and cuttle-fish, with their allies, the extinct belemnites, ammonites, and orthoceratites; and which include the shell-bearing animals, as sea-snails, whelks, cowries, mussels, oysters, terebratulæ, lingulæ, \&c.

3. Articulata.-Jointed animals; as insects, centipedes, scorpions, spiders, lobsters, cyclops, barnacles, and the extinct trilobites and eurspteri.

4. Radiata, or Colenterata.-Rayed animals. This sub-kingdom includes sea-cucumbers, sea-urchins, starfish, crinoids (stone lilies), corals, and the extinct pentremites, cystideans, and graptolites.

5. Protozoa.-Minute beings " retaining the form of nucleated cells, which manifest the common organic characters, but without the distinctive superadditions of true plants or animals." * Sponges, foraminifera, and infusorial animalcules are included in this sub-lingdom.

These plans of animal architecture are altered and modified in a thousand ways. However ungallant, it is more necessary to separate the "lassie fair and gentle"

"Palæontology," by Professor Owen, p. 4, et passim. 
from the nightingale and dove than from the hippopotamus or whale; while the winged butterfly of the air is far more nearly allied to the centipede or scorpion than it is to the humming-bird or bat.

The sub-kingdoms, therefore, are divided into CLasses, Orders, Families, Genera, Species.

Vertebrate animals are divided into four ClassesMammals, Binds, Reptiles, and Fishes. 


\section{IA P T R I.}

\section{Class $\mathrm{I}$.}

\section{ANIMALS THAT SUCKLE THEIR YOUNG. Mamalata.}

The Class Mammalia is divided into different Orders. Order 1. Two-Handed Animals (Bimana)-man.

2. FuUR-HANDED Aximals (Quadrumana)-monkeys of the old world, American monkeys, lemurs.

3. Flesh-eaters (Carnirora) - lion, wolf, hyena, bear, raccoon, badger, seal, morse.

4. Evex-toed, two or four, A mimals (Artiodactyla) hippopotamus, pig, camel, stag, cow, sheep.

5. Odd-Toed, one or three, Animals (Perissodactyla)horse, rhinoceros, hyrax, tapir.

6. Amimals with a Proboscis (Proljoscidea)-elephants.

7. Toxodontu (an extinct family, three species of which are known from rocks in South A merica)-toxodon.

S. Sirexs (Sirenia)-dugong, manatee.

9. Whale Aximals (Cetacea)-whale, porpoise, dolphin.

10. Haxd-Winged Anmals (Cheiroptera)-pteropus, bats, vampire.

11. Irsect-Eaters (Insectivora)-hedgehog, shrew, mole.

12. Axmils Wantixg TeEth in the fore part of their JAW (Edentata)-sloth, armadilio, anteater.

13. Gnawers (Rodentia)-rat, hare, squirrel, beaver, porcupine.

14. Pouched Axmals (Marsupialia)-liangaroo, wombat, opossum, dasyurus, koala, \&c.

15. Singled-vexted Axmals (Monotremata) - platypus, echidna.

\section{Order 1.-MAN. Bimana.}

Many questions occupy the attention of philosophers respecting the primordial organic type of humanity, the 
unity of the race, and indigenous races of men. Those who take an interest in speculating on such intricate problems will find food for thought in the enormous difference between man degraded, and man elevated, educated, and spiritualized; between the idolatrous sarage and the lord of the telescope, the steam-engine, and the electric telegraph.

The theology of science is at present in its infancy, and consequently liable to multitudes of errors. When the theologian shall have become more conversant with God's works, and the scientific man more of a theologian, we shall obtain more light. The laws of creation are the laws of God, and so also is the law of revelation to man's spirit.

Without referring to the subject under its religious aspect, I conceive that science teaches that there is an impassable hiatus between the intellectual capacities of the lowest race of men and those of the highest race of apes.

It is impossible to select a more degraded race of men, for example, than the Rock Veddahs, so graphically described by Sir Emerson Tennent, in his admirable work on Ceylon.

"Their language is limited to a very few words; and so degraded are some of these wretched outcasts, that it appears doubtful in certain cases whether they possess any language whatever. . . They have no knowledge of a God, nor of a future state; no temples, no idols, no altars, prayers nor charms; and, in short, no instinct of worship, except, it is reported, some addiction to ceremonies analogous to devil-worship, in order to avert storms and lightning. . . . So rude are the Veddahs in all respects, that they do not even bury their dead, but cover them with leaves and brushwood in the jungles. ... In form they are miserable objects, active but timid, and athletic though deformed, with large heads and misshapen limbs."

They have "projecting mouths, prominent teeth, flattened noses, stunted stature... The children are unsightly objects, entirely naked, with misshapen joints, 
huge heads, and protuberant stomachs; the women the most repulsire specimens of humanity ever seen in ans country. . . The Rock Teddahs have no idea of time or distance; no name for hours, days, or years. They hare no doctors, and no knowledge of medicine beyond the practice of applying bark and leares to a wound. They have no games, no amusement, no music; and as to education, it is so utterly unknown that the wild Veddahs are unable to count beyond five on their own fingers." I do not think it possible to select examples of men degraded, more striking than these savages of Ceylon. Iet re must never forget that these Veddahs shomed, on the very first attempt of civilization, that they possessed the human element of progress and improvement. In one colony, at Oomany, so remarkable is the change that the whole community have become Christians. "Their former appellation, derived from the peculiarity of their habits, can no longer apply; the distinction of Rock Veddahs has ceased to exist in that part of the country; ; all having more or less adopted the habits of villagers."

The Bushman of Africa is another instance of what we may term a degraded man, or at least, of an intellectually undereloped man; yet, however degraded the man may be, he possesses the power of progress; he has been endowed with mental faculties capable of improvement, which education immediately tends to develop.

Judging from the sculptures and relics of the earliest historic times, the races of men were as distinguishable then as now, and were then associated with particular climates and countries. We have no data which reveal to us the changes which have passed over the form of the typical human race, and produced character's so distinguishable as those of the Negro, Caucasian, or Mongolian. The animals that were contemporary with the earliest HISTORIC human beings were identical with the forms now existing, with the exception of a few which hare been destroyed by man's agency, and others which hare been remored from their original habitations. The 
races of domestic cattle are modified to a considerable extent; but there were modified varieties when the records of ancient Egypt were sculptured, and the wild animals are unchanged. It is now well known that human beings lived and died upon this earth's surface for long ages before that period which history and tradition hitherto assigned to the creation of the race. The archrologists of Northern Europe have divided the history of the human race into four great periods, knorn as the Christian, Iron, Bronze, and Stone periods. With the Bronze age we pass beyond the reach eren of tradition. The late important discoveries in Switzerland prove that an early race of human inhabitants constructed on the various lakes a series of "pile-works," or lake habitations, fashioned like the papous of $\mathrm{New}$ Guinea, "buts which, circular or square in form, are grouped on wooden platforms elevated a few feet abore the level of the water, supported by numerous piles driven into the mud, and connected with the land by a narrow bridge." Some of the pile-rrorks belong to the Bronze age, others go back to an age of Stone; and the number of stone implements which hare been found is quite astonishing. Human bones occur in these pileworks; and $\mathrm{Mr}$. Lubbock gires a long and able description of the implements, and remains of animals and plants associated with them. Amoug the relics are carbonised apples and pear's, resembling those which still grow wild in the Sriss forests; carbonised wheat, barley, and unlearened cakes. The remains of the animals prove that the period of the lake habitations was posterior to that of the Mammoth and Cave carnirora. Yet those ancient Swiss feasted on several animals now extinct in Switzerland, as the urus, the bison, the elk, the stag, the ibex, and the bear. The researches of Professors Steenstrup, Forchhammer, and Worsäae, also prove that in Demmark the whole country has undergome considerable physical alteration since it has been inhabited by human beings. TVe learn from Mr. Lubbock's interesting communications to "The Natural 
History Rerier," ** that there is sufficient evidence to prove that, during one part of the Stone period, Denmark was more intersected by fjords than it is now; that the land has encroached on the sea in some localities, and been denuded in others, since the rude inhabitants accumulated their "refuse heaps" of shells, and bones of birds and animals, some of which are extinct, and others no longer living on the coasts and land of Denmark; and among which refuse the investigator detects "rude flint implements," and "bones still bearing the marks of knives." The changes in the regetation of Denmark, as described to hare taken place since men inbabited the country, are rery remarkable:- "At present the beech roods are the pride of the country, and are considered by the Danes to be the finest in the world. Many of the trees are of great size, and the forests are popularly supposed to have existed from time immemorial." "At the time of the Romans, the country was covered by beech forests."

The peat mosses, howerer, reveal another history: they tell us that Denmark has passed through no less than three periods of arborescent regetation, corresponding to three stages of human civilization.

Before the Roman period, there was a time when the country was covered with oak-trees, and beeches were absent; while before the Oak period the country was covered by the pine (Pinus sylvestrus), which attained a "magnificent size," and "though for a long time pines have ceased to grow naturally in Denmark," human implements of bronze are found associated with the Oak period, but not among the relies of the pine forests below; while stone implements are found with the pines. Iron implements only occur among the beeches. Most interesting and instructive also is the history furnished by the animal remains found in in the refuse heaps, or "kitchen middens," of this Stone period.

* See Lubbock on the "Kjokkenmöldings," and "Ancient Lake Habi tations," Nat. Hist. Review for Oct. 1861 and Jan. 1862 
Those primitive Danes feasted largely on the oyster, the cockle, the mussel, and the whell. But the oyster has disappeared altogether from the coast, as the water is not now sufficiently salt, and the other species have become diminished in size. Remains of the capercailzie (Tetrao urogalluss), or cock of the wood, a bird which feeds mostly on the buds of the pine, and could have lived in Denmark only during the Pine period, are associated with the bones of the nearly extinct great auk (Alca impennis), and those of the extinct bull (Bos primigenius), among the refuse food-heaps of the men of that earlier Stone age. I say earlier Stone age, as it was not the earliest, for human implements of flint have been discovered in stratified drifts in France, and several localities in Great Britain, associated with the remains of the mammoth and rhinoceros; and these drifts are proved by the physical geology of their position, as mell as by the associated fossil remains, to be vastly older than even the relics of the ancient Danes.*

In a work of this kind, it is impossible to enter into much detail, and I must refer my readers to Sir Charles Lyell's work on "The Geological Evidences of the Antiquity of MIan." I will, however, gire a few notes, which may be useful by may of reference, respecting the different geological periods into which it has been found convenient to divide the various groups of stratified deposits, which are known as the Tertiary, Post-Tertiary, and Recent strata. (See diagram at title page.)

Eocene is the term invented by Sir Charles Lyell for the lowest and most ancient group of those tertiary rocks which succeed the secondary group of deposits in stratigraphical position, and in which the prototypes of almost all existing mammals for the first time make their appearance. Eocene means the damn of recent animals. The Miocene deposits, which succeed the

* See "The Geology of the Railway from Morcester to Hereford," by the author. 
Eocene tertiaries, contain fercer recent shells than the Pliocene, while in the Post-Pliocene deposits, which overlie the latest of the Pliocene, the fossil shells are of existing species.

\section{The Eocene Period.}

Species of shells are known to be much longer-lived than those of mammalia, and many species and genera of mammals have been called into existence, lived for ages, and become extinct, during the period that most of our common mollusks have been living in our seas.

The meaning of the term Dawn, as applied to the life of former days, may be understood when we say, that of all the thousands of fossils, consisting of specimens of plants, shells, fish, reptiles, birds, and mammals disinterred from the Eocene tertiaries, only $3 \frac{3}{2}$ per cent. of the shells are still living, and none of the higher animals. During that Dawn epoch, the sites of London and Paris were washed over by the waves of a rolling sea, temanted by sharks and turtles. Rivers flowed into it and washed down the remains of strange, tapir-like, land quadrupeds. The trees that flourished on the land are known to be allied to the spice-trees and the palms by their leaves and fruit. Thus the climate of the Dawn epoch in these latitudes is believed to have been warmer than the present climate of Great Britain.

\section{The Miocene Period.}

The proportion of living species of shells in these deposits is considered to be about 17 per cent. With the exception of some deposits at Hempstead, in the Isle of Wight, and some volcanic ash-beds, containing the remains of plants, associated with lavas, in the west of Scotland, we have no rocks of this age in Great Britain.

We know, howerer, from the revelations of these deposits in other lands, that the geographical changes of 
land and water surface have been enormous since the commencement of the Miocene epoch. The Atlantic rolls its waves over the site of an extinct continent that stretched its hills and vales north and south, east and rest, in that Miocene epoch. During this period the rolcanic mountains of central France were in full action, and there tuff's and ashes have preserved hundreds of relics of animals then living; while thousands of square miles of what was an ocean-bed during the Hiocene period, have, in India, been elevated into lands, and now furnish hundreds of skeletons of extinct animals that were swept into the waters and preserved in silt and mud. All the species, and nearly all the genera of Jiocene mammalia belong to different types from those now living.

\section{The Pliocene Period.}

In rocks of this age, the number of fossil shells identical with forms now living, ranges from 50 to 90 per cent. The enormous lapse of ages that must have gone by between the close of the Pliocene period and the recent or present period, may be gathered from the fiact that the long Glacial period intervened, with all its urctic phenomena, extending over thousands of years.

\section{The Glacial and Post-Tertiary Periods.}

One of the marvels revealed by the relics of animals and plants entombed in the rocks, is the fact that, as this planet circles in space around the sun, changes of climate are graaually brought about, though myriads of ages elapse between the commencement of such a change, the fulfilment of the epoch, its close, and the commence. ment of the change that ensues. I mentioned that in the Eocene epoch, the whole history of animal life, and plant life, tells us that a warmer climate than we now enjoy appertained to Great Britain, oring, probably, to certain geographical distributions of lik surface and 
water surface, to the history of which we have not found the clue. Ages and ages passed aray, and even in the Pliocene epocb, during the deposition of a series of beds termed the Coralline crag, the presence of such shells as Pyrula, Cassidaria, Terebra, Voluta, prove a warmer, and, as it were, more southern influence in our seas. * Tet in the beds that succeed the Coralline crag (the Red crag), there is good proof of the commencement of a refrigeration of climate, and which refrigeration of climate went on for age after age, until glaciers filled every mountain valley in Scotland and Wales, $\uparrow$ until the seas were floated over by drifting icebergs and icerafts, depositing their burdens of drifting boulders as they melted. The Glacial epoch passed away during the lapse of ages, and a more temperate climate succeeded; it may be to be again succeeded, in the far off futurity, by warmer, and again by colder climatal influences than now affect our present temperate modifications.

It is now ascertained, principally from the researches of Dr. Falconer, that the Cave mammalia found in such abundance in ossiferous cares and fissures, were post glacial and that, when these animals were living, a more temperate climate had succeeded in these latitudes to the bitter winters of the boulder-clay period.

Sir Charles Lyell divides the Post-Tertiary period into two epochs, the Recent and the Post-Pliocene periods ; the Recent comprehending those deposits in which not only all the shells, but all the Fossil mammalia are of living species; and the Post-Pliocene, those strata in which the shells being recent, a portion, and often a considerable portion of the accompanying quadrupeds belong to extinct species. In order to become acquainted with the eridence which proves the enormous age of the deposits in which the first traces of men are detected it is necessary to study the researches and publications of

* Woodward on Recent and Fossil Shells, p. 421.

+ See Professor Ramsay's work on the Glaciers of Wales, in the contributions of the Alpine Club.

+ Lyell on "Antiquity of MIan." 
Iyell, Boucher de Perthes, Prestrich, and Falconer. It is now most distinctly shewn that an ancient race of men lived in times so remote, that we can form no conception of their antiquity. The gravels mhich contain the reapons they used were accumulated in the channels of ancient rivers, which flowed in some instances at levels higher, by a hundred feet, than the existing rivers now flow, and before the valleys had been scooped out into their present form. The glacial epoch had passed amay, but there is evidence that the climate mas still colder than at present, and it is probable that our English rivers were frozen over each winter like those of North America. There is also no doubt that at least two species of elephant, the cave lion, and woolly rhinoceros were contemporary with man, in England and in France. These animals gradually died out, while a few lingering quadrupeds, such as the musk buffalo and reindeer retreated to the distant north.

Nevertheless, the earliest record of the existence of man, as an inhabitant of this planet, is immensely posterior to the Miocene epoch in which the oldest known ape is known to have lived. Our first knowledge of man is that he appears as a reasoning being. Apes were apes myriads of ages before we have any evidence of man's existence, and are apes still.

The question of men haring been developed from apes is one much mooted and disputed on by philosophers of the present day. The fairy, in Professor Kingsley's "Water Babies," tells her pupil and protégé, "Folks say, now, that I can make beasts into men, by circumstance, and selection, and competition, and so forth. Well perhaps they are wrong, and perbaps again they are right. Whatever their ancestors were, men they are, and I advise them to behare as such, and act accordingly. Let them recollect this, that there are two sides to every question, and a downhill as well as an uphill road; and if I can turn beasts into men, I can, by the same laws of circumstance, and selection, and competition, turn men into beasts." 


\section{Order 2.-FOUR-HANDED ANIMAIS. \\ Quadrumana.}

The term Quadrumana (four-handed) is applied to animals the extremities of whose limbs resemble the human hand, so that they climb with ease. This order is subdivided into three families :-

\section{Catarhini (Old World monkeys). \\ 2. Platyrhini (American monkeys). \\ 3. Strepsirhisi (lemurs).}

The apertures of the nostrils in these groups present distinguishing features.

The monkeys of the eastern hemisphere (Catarhini) which inhabit Africa, Arabia, India, Japan, China, Ceylon, and the islands of the Indian Archipelago have, like men, thirty-two teeth, and are characterized by nostrils which converge at their lower extremity, and are there separated by a very narrow cartilage.

The American monkeys (Platyrhini) have the nostrils opening in a direction parallel to each other, and separated by a cartilage which is as wide at the base as at the upper extremity. They have also four more teeth than the Old World apes.

The lemurs (Strepsirhini) have a curved opening in their nostrils.

As an instance of the difficulty of drawing a broad line of demarcation between those animals which appear to afford intermediate links of transition, I would draw your attention to the lemurs, one of which, the flying lemur, seems to connect the four-handed animals or monkeys with the wing-handed animals or bats. The lemurs inhabit the island of Madagascar, and Cuvier ranked the winged lemur (Galeopithecus) with the bats. Some comparative anatomists believe that there is a gradation from the monkeys through the lemurs, galagos, and galeopithecus, to the bats.

The extraordinary lemurine animal, the Aye-Aye, of which the Zoological Society of London now possesses 
a specimen, appears to connect the lemurs with the Rodentia, but it is really a quadrumanous animal. The aye-aye (Cheiromys) is a nocturnal animal, and em. ploys its long slender finger to extract its food.

In structure, the gorilla offers the nearest approach to man of any known ape, recent or fossil. Professor Oren, when comparing the structure of the highest of the Quadrumana with man, thus expressed himself at the late meeting of the British Association at Oxford:

"Taking the brain of the gorilla, it presented more differences as compared with the brain of man, than it did when compared with the brains of the very lowest and most problematical form of the Quadrumana. The deficiercies in cerebral structure between the gorilla and man were inmense. The posterior lubes of the cerebrum in man presented parts which were wholly absent in the gorilla. The same remarliable differences of structure were seen in other parts of the body; yet he would especially refer to the structure of the great toe in man, which was constructed to enable him to assume the upright position; whilst in the lower monkeys it was impossible, from the structure of their feet, that they should do so." *

The should not, however, be dealing fairly with our readers, if we did not state that many distinguished comparative anatomists differ from Professor Owen on the brain structure of the gorilla. At Oxford, Professor Huxley replied at some length to the remarlis of Professor Owen:-

"He denied altogether that the difference between the brain of the gorilla and man was so great as represented by Professor Owen, and appealed to the published dissections of Tiedemann and others. From the study of the structure of the brain of the Quadrumana, he maintained that the difference between man and the highest monkey was not so great as between the highest and the lowest monkey. He maintained also, with regard to the limbs, that there was more difference between the toeless monkeys and the gorilla, than between the latter and man. He believed that the great feature which distinguished man from the monkey was the gift of speech."

* Athencerm, July $7,1560$. 
With regard to the habits and nature of the gorilla, the following is the interesting description given by Professor Oren :-

"Gorilla-land is a richly-wooded extent of the western part of Africa, traversed by the rivers Danger and Gaboon, and extending from the equator to the 10 th or 15 th degree of south latitude. The part where the gorilla has been most frequently met with, presents a succession of hill and dale, the heights crowned witl lofty trees, the valleys covered by coarse grass, with partial scrub or scattered shrubs.

"Fruits and other rich and nutritious productions of the vegetable kingdom, constitute the staple food of the gorilla, as they do of the chimpanzee. The molar teeth, which alone truly indicate the diet of an animal, accord with the statements as to the frugivorous character of the gorilla; but they also sufficiently answer to an omnivorous habit to suggest that the eggs and callow brood of nests discovered in the trees frequented by the gorilla might not be unacceptable.

"The gorilla makes a sleeping-place like a hammock, comnecting the branches of a sheltered and thickly-leaved part of a tree by means of the long tough slender stems of parasitic plants, and lining it with the broad dried fronds of palms, or with long grass. This hammock-like abode nay be seen at different lieights, from 10 to 40 feet from the ground, but there is never more than one such nest in a tree.

"The strengtl of the gorilla is such as to make him a match for" a lion, whose tusks his own almost rival. Over the leopard, invading the lower branches of the gorilla's dwelling-tree, he will gain an easier victory; and the huge canines, with which only the male gorilla is furnished, doubtless have been assigned to him fur defend. ing his mate and offspring.

"The redeeming quality in this fragmentary history of the gorilliw is the male's care of his family, and the female's cerotion to her young.

"It is reported that a French natural-history collector, accompanying a party of the Gaboon negroes into the gorilla woods, surprised a female with two young ones on a large boabdad (Adansonian), which stood some distance from the nearest clump. She descended the tree with the youngest clinging to her neck, and made off rapidly on all-fours to the forest, and escaped. The deserted young one on seeing the approach of the men, began to utter piercing cries. The mother, having disposed of her infant in safety, returned to rescue the older offspring; but before she could descend with it, her retreat was cut off. Seeing one of the negroes level his musket at her, she, clasping her young with one arm, waved the other, as if deprecating the shot. The ball passed 
through her heart, and she fell with her young one clinging to her. It was a male, and survived the voyage to Havre, where it died on arriving.

"A bold negro, the leader of an elephant-hunting expedition, being offered a hundred dollars if he would bring back a live gorilla, replied, "If you gave me the weight of yonder hill in gold coins, I could not do it!'

"All the terms of the aborigines in reference to the gorilla imply their opinion of his close kinship to themselves. But they have a low opinion of his intelligence. They say that during the rainy season he builds a house without a roof. The natives on their huntiog excursions light fires for their comfort and protection by night; when they have gone away, they affirn that the gorilla will come down and warm himself at the smouldering embers, but has not wit enough to throw on more wood, out of the surrounding abundance, to keep the fire burning, - ' the stupid old man!'"*

The Monkey-House at the Zoological Gardens in Regent's Park contains many species and characteristic forms of the monkey tribe, and entire skeletons of the gorilla may be seen in the British Museum. My friend Dr. Sclater describes the most characteristic species in the Zoological Gardens, in his Guide-book, sufficiently for the principles of study and examination. In the days of Cuvier no species of fossil monkey was known; but sereral species have been discovered since, in rocks of Tertiary age.

The supposed fossil monkey of Eocene date, known as the "Eopithecus" has, according to Sir C. Lyell, turned out to be a myth. MI. Rutimeyer, however, has just announced the discovery in Eocene strata of a monkey allied to the lemurs. The fossil jaw of this animal was found in the Swiss Jura, but Sir Charles Lyell evidently feels uncertain respecting the monkey character of the specimen. $t$ Fossil remains of monkeys have been found in Brazil, India, France, and Greece. The Dryopithecus, or ape of the wood, was a long armed gibbon nearly equal to man in stature, and was found in Miocene beds in the south of France.

\footnotetext{
* Pro. Zool. Soc., Jan. 11, 1859.

+ Antiquity of Man, p. 500.
} 


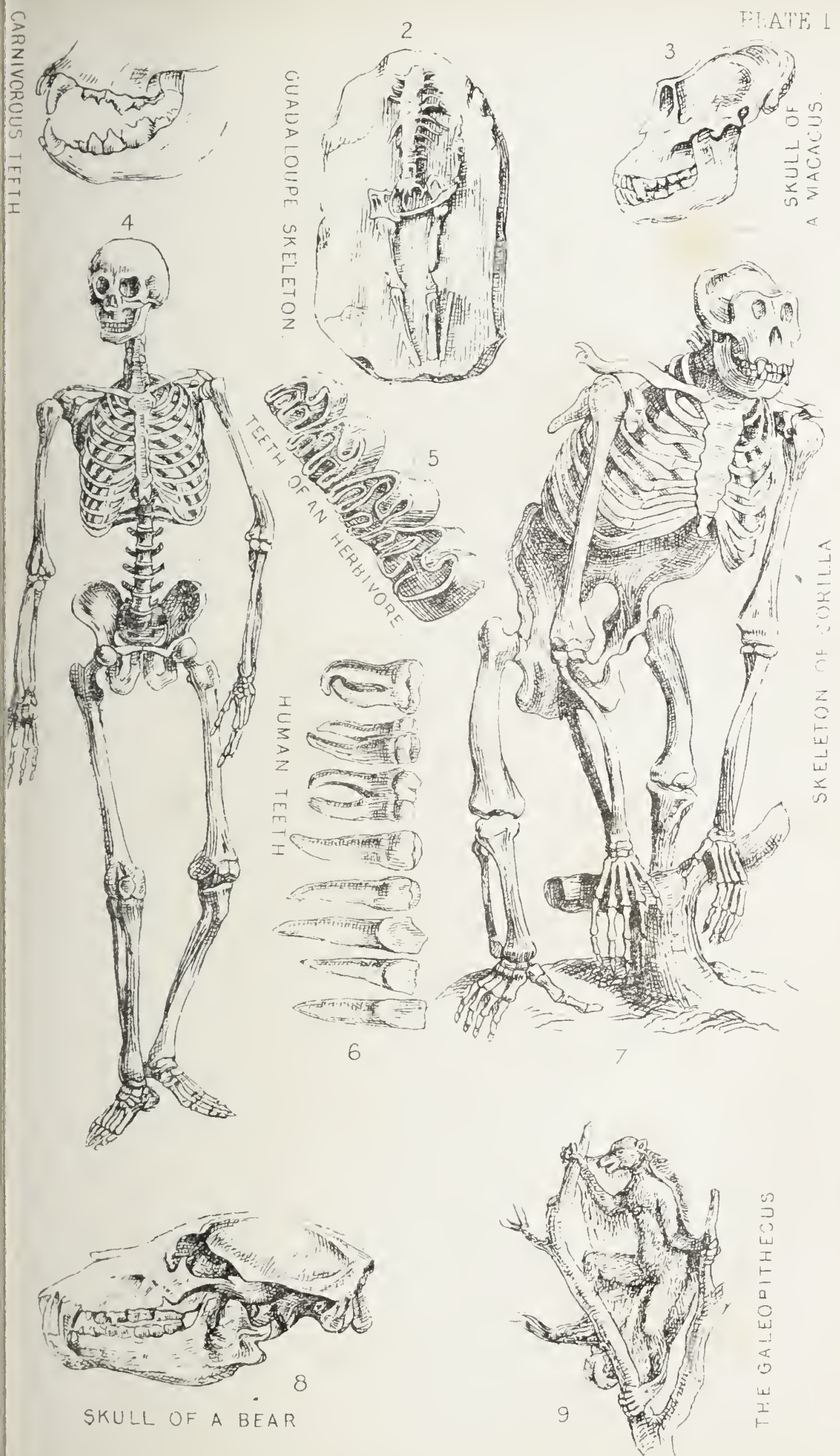





\section{Order 3.-FLESH-EATING ANIMALS. \\ Carnivora.}

Beasts of prey, as the Carnivora are sometimes called, are divided into three groups, according to the structure of their feet:-

1. Toe-Walkers (Digitigrada)-lion, wolf, hyena, weasel.

2. Flat-soled Walkers (Plantigrada) - bear, racoon, badger.

3. FiN-FOoted (Pinnigrada)-seal, morse.

1. Digitigrada. - It is well for the tyro to become acquainted with the structure of a carnivorous jaw, and to study its adaptation for the destruction of other animals. We recommend, as a first step, a knowledge of teeth, and the difference between incisors, canines, and molars. This may appear a simple recommendation, but as I hare known the jaw of a boar labelled as that of a wolf, it may not be altogether unnecessary.

An examination of the dentition of the Norway wolf and the brown hyena will convince the observer that those animals were never intended to be vegetarians. If this be a law and truth of the Creator's established now, it was also a truth millions of ages ago.

The student of Natural History should take every opportunity of examining living forms of animals, and their prepared skeletous. The writer of these Notes has received great advantage from occasional visits to the British Museum, the Museum of the Royal College of Surgeons, and the Gardens of the Zoological Society of London, with the admirable "Guide to the Gardens" by the late and present secretaries to the Society for his direction. Ferr persons have the requisite opportunities for examination into the minutia and details of Comparative Anatomy, Palæontology, or other branches of the Science of Nature; but most of us have opportunities of becoming acquainted with the principles of such snowledge, if we make the most of our opportunities. 
Living examples of the Digitigrade (toe-walkers) Carnivora may be seen in the cages of these animals in the Regent's Park - the house of the great Carnivora. Here are splendid specimens of the lions of Asia and Africa (Felis Leo); the tiger (Felis Tigris), now purely Asiatic in its range; leopards from Africa and Asia; the puma (Felis concolor), called "the Lion" of South America; and the "American Tiger," the savage and powerful jaguar. Those who have seen the fossil relics of our English caves, the bone-cares of the geologist, will look with interest at the hrenas, when they remember that thousands of these animals were formerly denizens of Great Britain. In Regent's Park there is a specimen of the brown hyena, which, Dr. Sclater informs us, is a rare animal in collections, and the only one which has ever been brought alive to England.

As far back, in pre-existing ages, as the middle of the Secondary epoch, there were insectivorous Mammals; and in the Miocene epoch there lived, says Professor Owen, "in England and continental Europe, a peculiarly destructive feline quadruped, with the upper canines much elongated, trenchant, sharp-pointed, sabre-shaped; it was represented by species as large as a lion, and by others of the size of a leopard." These destructive carnirores had their representatives in the Post-Pliocene epoch, which were the contemporaries of the gigantic cave bear and hyena, and the slayers of extinct oxen and deer in ancient England. Animals allied to the dog and for have been found fossil, and a species of hyena was very numerous formerly in England. The caves of Devonshire and Somersetshire were tenanted by successive generations of hyenas, as is testified by their peculiar relics of fossil dung. Huge carnivores must have formerly swarmed in Great Britain during the cave period, and now the only representative of the dog tribe is the fox, of the tiger and lion the wild cat, and of the bear the badger.

I do not believe in the theory which supposes that the cave bones mere, in all instances, washed into the hollows 
and fissures of rocks. In some instances, I believe the caves are remains of rock fissures, through which streams sometimes flowed, as streams flow now in Ireland, through fissures in the Mountain Limestone. In many instances, the caves must have been the dens of the large cave Carnivora, the cave lion, hyena, and cave bear. These animals not only destroyed the ruminants, the wild cattle, horses, and deer, the remains of which, with those of sucking elephants, are found in such abundance in the caves, but they dragged their bones piecemeal to their haunts, where they gare birth to their own young, and where the remains of the baby hyena are frequently found mingled with those of its aged parent, and with the relics of hundreds of their prey. Probably the histories of the bone caves are different according to their position, and it would not be safe to generalize from any particular case.

While some of these caverns must have been used as dens by the great cave Carnivora, mammalian remains may have been washed into others, as would happen now, after a stampede of wild animals succeeded by a river flood, in the buffalo regions of America, if there were rock-fissures, cares, or hollows, within flood's way, on the river shore. At Banwell Cave, in Somersetshire, there is proof of the former existence of an underground rivulet, the flow of which has been apparently reversed by the elevation of the Carboniferous limestone, since the Cave period; and I beliere that elevation of the land has been generally the cause of the closing of fissures, and the obliteration of many cave features throughout the south-west coasts of England. The bones of men, as well as their weapons, have been found entombed in caves, associated with the relics of extinct Carnivorous animals.

2. Plañtarada. - Bears, racoons, badgers, and gluttons, place the sole of their feet flatly on the ground, and are therefore termed Plantigrades. Badgers will probably soon become extinct in Great Britain. They were once abundant in England, especially in the neighbourhood of Red DIarley, Worcestershire.

Specimens of all these animals may be seen in the 
Zoological Gardens. There are bears of Europe, Syria, Thibet, and America; and the grand Polar bear (Thalassarctos maritimus). Of this animal Dr. Sclater writes as follows :-

"The Polar bear, or ice bear, attains probably to the largest size of all this group, for Captain Lyon records the capture of one which measured eight feet seven and a half inches in extreme length, and weighed 1,600 pounds. The female has now lived in the menagerie upwards of eleven years; the male was obtained in October, 1850. When standing on his hind legss, he can reach to the height of ten feet six inches with his muzzle. To capture an animal of this dimensions, and incarcerate him without injury in a cask not exceeding five feet six inches in length, in which he lived for at least three months, and in which he was ultimately conveyed to the gardens, is a feat which few men would accomplish but the intrepid pursuers of the whale, by whom polar bears are generally brought home as a supplemental venture on their return from the Northern Seas to Peterhead."

The remains of a gigantic bear (Ursus spelceus) are continually tound in England, in the cares and alluvia of the Post-Pliocene period, as also another species ( $U$. priscus). Both these species are now extinct. The perfect skull of the brown bear (Ursus arctos), from a peat bog in the vale of Annan, is in the museum of Sip William Jardine. The bear has not been long extinct in Scotland.

MI. Rutimeyer found the European bear (Ursus arctos) and badger associated with the human relics, in the mud of the Swiss lake dwellings, but he found no remnants of the cave bear, or of any other of the extinct carnivora. Sir Charles Lyell, in his rork on the "Antiquity of Man," cites several instances in which the bones of men who lived at an earlier period than the lake dwellers, have been found associated with the remains of the cave bear and hyena.

Mr. William Beard, of Banwell, Somerset, is in posses. sion of some fine remains of the great care bear ( $U_{r} s u s$ spelcus), indeed he has collected a wonderful assemblage of the remains of the extinct mammalia of the Cave period from sis caves, situated within a few miles of his 
own house. Among his specimens I recognised the remains of the Mammoth (E.primigenius) and probably of another species of Elephant, with some teetl of fietal elephants, the hyena, cave lion, rlinoceros, horse, with immense quantities of the remains of deer and other rumivants.

Specimens of the racoon (Procyon lotor) of North America, and an allied species-the Crab-eating racoon (P. cancivorus) ; also of the glutton of Northern Europe (Guto articus), are to be seen in the "Small Mammalia House."

3. Pincigrada. - The Pinnigrade (fin-footed) seal (Phoca vitutina), has a pond to itself in the gardens, where a crowd may be generally seen admiring the docility of the animal. The great walrus is, like the seal, a fin-footed caruivorous Mammal.

Seals have been found fossil, and also relics of the Walrus. The jaws and teeth of the extinct carnivores are generally so well preserved that no one, save persons with diseased imaginations, can look at them and not be convinced that they were the handiworks of the Creator -startling evidences of desigu, and ritnesses of the truth that, from the begining, He who created life also instituted death.

\section{Order 4.-EVEN-TOED ANIMIAIS (two or four). Artiodactyla.}

This order is divided into two families :-

1. Not Chewers of the Cud (Non-ruminantia) - hippopotamus, pig, anoplotherium.

2. Chewers of The CUd (Ruminantia)-deer, ox, goat, camel, sheep.

1. NoN-RUMINANTIA.-The pig is the existing representative of a very ancient race of mammals, which lived and died upon this earth long before there were Christians to devour, or Jews to abhor their flesh. 
The same species of wild boar that was hunted by our forefathers was contemporary with the mammoth, the care bear, and the long-haired rhinoceros. Some persons imagine that geology deals only with fossil shell or fishes; but there is a vast deal of interest attached to the geological history of the predecessors and representatives of our domestic animals. We know that the wild ancestor of our domestic pigs mas in existence before the separation of England from the continent of Europe; and that the hunter, if hunter's lived, might have chased the boar through forests, the site of which is now occupied by the waves of the English Channel. Nammoths, tigers, and rhinoceroses perished, but the wild boar lived and lives still, on the continent of Europe, though extinct here. Our wild boar had his representative in the extinct Chœropotamus during the Dawn epoch.

The "Swine House," in the Zoological Gardens of Regent's Park, contains numerous living specimens of the Suidæ, or swine family. The Wart hog (Phacochoerus Athiopicus), two or three species of which are found in Africa; and the peccary, an American species of hog, are very singular forms of the swine family.

The hippopotamus houses of the Society contain a pair of these extraordinary animals, now confined to Africa, although formerly abundant in Europe.

The following account of the capture of the older of the two is from Dr. Sclater's Guide to the gardens of the Zoological Society.

"In the month of July, 1849, a party of hunters, especially organized for the purpose, succeeded in capturing a calf of some three days old on the island of Obaysch, in the White Nile. When found in the reedy covert to which the mother had confined him, the hippopotamus, who now weighs at least four tons, was of such small dimensions that the chief huntsman took him up in his arms to carry him to the boat from which his men had landed. Covered, however, with a coat of slime more slippery than that of any fish, the calf glided from his grasp, and struggled to regain the safe recesses of the river. Quicker than he, the hunter used the gaffhook fastened to his spear-of the same model as that used for a like purpose at the mouth of the Nile 3,000 years before,-and 
struck him on the side, where a scar still marks the wound, and safely held him.

"From Obaysch, many hundred miles above Cairo, the hippo. potamus travelled down in charge of the hunters and a company of infantry, who finally landed him at the British Agency in the month of November, 1849."

The hippopotamus is first met with in Pliocene strata; therefore, is not of so ancient a family as the hog, for a true boar is found in Miocene deposits.

The remains of the hippopotamus are found in PostPliocene beds and cares, and in districts, says Sir C. Lyell, "where there are now scarce a rill of rumning water, much less a river in which such quadrupeds could swim." Teeth of several individuals both young and old were found by Col. Wood, in the cares of Gower, and Te have their remains in Worcestershire, in those old river gravels, which were described long ago by Mr. IIugh Strickland.

It is in these beds that the explorer finds in Worcestershire and Gloucestershire such numerous relics of the extinct manmalia. Remains of the elephant, hippopotamus, rhinoceros, hyena, several species of deer, and two or three of bos, were collected by the late Mr. Hugh Strickland and the Rer. W. Parker, of Comberton, from these drifts abore the Aron, at Bricklehampton, Cropthorne, and Fladbury; and by Mr. Jabez Allies and others, from Kempsey, on the Serern.

We find that on the Aron they contain numerous freshwater shells. The most abundant species are cyclas and cornea; but with these Mr. Strickland found the Unio littoralis and the Cyrenafluminalis which is now extinct in Europe, though living in the Nile and Cashmere.

I was formerly inclined to correlate the drifts with the silts of the Lake period. I was mistaken! The low-level drifts are altogether antecedent to and independent of the detritus which fills up the beds of those fresh-water lakes which preceded the present physical configuration of the river valley. The low-level drifts are the remains of the beds of older and broader rivers. 
The Anoplotherium (a beast without weapons) is an animal appertaining to an extinct genus of quadrupeds, which were allied to the hippopotamus and pig, though distantly. There are several species found fossil in the Paris Tertiaries, varying from the size of a hare to that of a fallow deer. The remains of these animals are found in strata as old as the Eocene, or Dawn epoch. Professor Owen has determined that the Anoplotherium resembled in several particulars the embryo Ruminant, but that the true Ruminant with cloven feet and ruminating stomach did not appear until a later period in the Tertiary series.

\section{Ruminantia.}

The chewers of the cud are, of all animals, those which are the most useful to man. It is evident that the teeth of the ox were designed for the mastication of vegetables, and not for seizing other animals and tearing flesh. There are also various other modifications in the framework, such as the horny hoof instead of powerfinl retractile claws.

Every young palæontologist should become acquainted with the differences between the palæontological characters of a Ruminant and a Feline Carnivore as portrayed by Professor Owen.*

The bison of America and the Aurochs of Europe were formerly among the specimens in Regent's Park, but they are now dead. The Ruminants are well represented. There are many antelopes distributed in various parts of the establishment. The Nylgau, one of the most striking antelopes, is the largest of the Asiatic species; and there are various species of deer, among them the magnificent wapiti of America (Cervus Canadensis), with the brindled gnu (Catoblepas Gorgon), in the well-stored deer-houses. We have also the privilege of beholding a splendid collection of giraffes, several of which were born in the gardens. The parent giraffes

* Palæontology, p. 378, \&c. 
were taken by M. Thibaut in the south-west of Kordofan, with the aid of a party of Arab hunters. The difficulty of the capture was considerable. The eland (Oryx leucoryx) is a beautiful beast, and re learn from Dr. Sclater that this animal is likely to become valuable in an economic and gastronomic point of view. "The eland breeds readily in confinement; and there is every probability that in a few years this noble animal will be a permanent inhabitant of many parks in the United Kingdom."

A species of aboriginal British ox, with very short horns and long-fronted head (Bos longifrons) was coexistent with the ancient Britons. The remains of this animal are associated with the bones of the hippopotamus in the ancient deposits of the Aron. A gigantic or (Bos primigenius) once roamed throughout England. Mr. Strickland, of Apperley Court, possesses a fine head of this species from the ancient fluviatile beds of Cropthorne, Worcestershire. It was discovered by his lamented son, the distinguished Hugh Strickland. The musk buffalo (Bubalus moschatus), which inhabits the coldest regions of North America, and which derives its subsistence ir regions as far north as between the 60th and 66th parallels of north latitude, should be mentioned, as a still existing link, a lingering remnant, of a tribe of large animals which once lived in thousands in these latitudes. The musk buffalo was contemporary with the extinct mammoth, and the extinct long-baired, woolly rhinoceros. Like these animals, it possesses a woolly coat beneath coarse hair. Its remains have been found in England, associated with those of the mam. moth, and Tichorine rhinoceros; and Professor Owen remarlis that "as this quadruped has a constitution fitting it at present to inhabit the high northern regions of America, we can hardly doubt that its former companions, the warmly clad mammoth and the two horned woolly rhinoceros, were in like mamner capable of supporting life in a cold climate, ${ }^{*}$

* Geol. Quart. Journal vol. 12, p. 124. 
As far as I know, remains of sheep have not been detected in beds of earlier date than the Post-Pliocene deposits.*

Most of the existing species of deer are, however, pigmies when compared with some species that have become extinct. The antlers of the reindeer (Cervus tarandus) are small compared with those of the gigantic "Irish elk" (MLgaceros Hibemicus), which was formerly very abundant in Ireland and the Isle of Man.. Its remains have also been found in England. The remains of this great Irish deer (Megaceros) are first found in the Red crag; it lived through the long Glacial epoch, was the contemporary of the mammoth and the longhaired rhinoceros, while it is not improbable that a pre-historic buman race slew the last of these noble deer. We learn from Professor Owen that this animal was a true deer, not an "elk," and "intermediate between the fallow and reindeer." The Earl of Enniskillen possesses some magnificent heads and one entire skeleton of this animal. Portions of antlers of different species of deer are abundant in the drifts and old lake beds of all parts of England. I possess a fine antler of the existing red deer (C. Elaphus) which, overlaid by thirty-seven feet of alluvial Severn silt, Tas disinterred at the great dock rorks of the Severn Navigation Company at Tewkesbury. The Severn alluvium was excavated down to the lacustrine silt. The overlying allurium, or produce of the overflowings of the existing Serern, is some trenty feet in thickness. Below this was a stiff tenacious clay; and below this, again, a black lacustrine silt, containing freshwater shells of species now living in the Severn and Aron, wood, a jar of ancient pottery, now in the possession of Sir Charles Lyell, and a fossilized antler of a species of red deer. The pottery was about thirty feet, and the red deer's hom was thirty-seven feet and a half from the surface. Both lay in the lake silt.

* See Roberts's "Rocks of Worcestershire," p. 233, for information on mammalian bones in the Worcestershire drifts. 
Lieut.-Col. E. R. Wood extracted no less than one thousand antlers of the reindeer from one fissure, called Bosco's den, among the bone cares of Gower, in Glamorganshire.

Both the linown species of the genus Camelus, the common camel (Camelus dromedarius), and the Bactrian camel (Camelus Bactrianus) are to be seen in the camel house of the gardens; and the Zoological Society possesses three species of wild sheep and two of wild goats, several of which have reproduced in the gardens.

The true camels are exclusirely confined to the Old World, but are represented in America, by four species of llama. The alpaca or paco, a herd of which has been lately imported to Australia, where they thrive remarkably well; the vicugna, a mountain species of Chili; the guamoco of Patagonia, and the llama, the only beast of burden, in former days, possessed by the natices. There are specimens of these animals in Regent's Park. The macruachenia is an extinct South American mammal, distantly related to the guanoco, and it is certain that this curious quadruped lived long after the sea was inhabited by its present shells, for recent marine shells are found on the step-formed plains which must have been elevated before the mud was deposited, in which $\mathrm{M}$ r. Darwin himself discovered half the skeleton of $\mathrm{s}$ macrauchenia, an animal as large as a camel. Professor Huxley has also described another macrauchenia ( $M I_{\text {. }}$ Boliviensis), the fossil remains of which were obtained by Mr. David Forbes, from the mines of Corocoro, in Bolivia. It is very interesting to observe, says MIr. Huxley, "that during the probable Post-Pleistocene epoch, a small and a large species of more or less Auchenoid mammal ranged the mountains and the plains of South America respectively, just as the present small ricugna is found in the highlands, and the large guanoco in the plains of the same continent."

The earliest known fossil examples of ruminant animals have been found in lacustrine deposits, of Miocene age, in Auvergne. There is a fine collection of the remaius 
of the microtherium (Cainotherium) in the British Museum; and according to the notes of Mr. Carter Blake on this small herbivore, it is just one of those remarkable animals which may furnish the comparative anatomist with data, whereon to work out the problem of Natural Selection.

\section{Order 5.-ODD-TOED ANIMALS (one or three). Perissodactyla.}

This order is divided into two families:-

1. Solid-Hoofed (Solipedia)-horse.

2. Thick-Skinned (Pachydermata)-rhinoceros, tapir, hyrax.

1. Solipedia.-The ancient appellation "soliped" means whole-hoofed, and applies to the equine genus, a family of quadrupeds so useful to man that it was formerly supposed horses and asses were created especially for man's purposes. We now know that there were antetypes and representatives, in bygone epochs, of the common horse.

When the Spaniards discovered America, no horse was in existence throughout the length and breadth of that Tast continent; but, being introduced, it has run wild, and in South America abounds in large herds. Yet America bad formerly a horse which became extinct before the days of the Incas and Indians, and the remains of which are imbedded with enormous American sloths, armadillos, and other animals, which are also themselves extinct, although the shells that were their contemporaries are still living.

No less than twelve equine species, says Sir C. Lyell, belonging to seven genera (including the Miocene Anchitherium of Nebraska), have been detected in the Tertiary and Post-Tertiary formations of the United States.

A representative of the horse (Architherium) lired in 
the Damn period, and there were some extraordinary forms,--one called Hipparion, a three-hoofed horse, and another a beast between the horse and rhinoceros (Elasmotherium), which lived in the days of those Miocene tertiaries, when volcanic action was rife in the north of Ireland and west of Scotland, and in the plains of central France.

The Elasmotherium reminds us of a series of facts alluded to by Professor Huxley, in his "Lectures to Working Men," and which are well worthy of notice. "The splint-like bones in the leg of the horse correspond with bones which belong to certain toes and fingers in the human hand and foot. In the horse they are quite rudimentary; so that this animal has but one finger in his fore-foot, and one toe in his hind-foot." But the rhinoceros, the hipparion, and the elasmotherium, all animals closely allied to the horse, have more toes than the horse ; so comparative anatomists say, "that animals, in an anatomical sense nearly related to the horse, have those parts which are rudimentary in him fully developed."

Professor Oren says, "that the common British fossil liorse (Equus fossitis), of which there are so many remains found in our bone caverns and fluviatile deposits, was characterised by a larger head than the domesticated races. The Genus Equus includes the ass, zebra, quagga, and the kiang (Equns hemionus), which is probably the wild horse of Asia, described by Pallas, the quagga ( $E$. quagga); zebra, and wild asses of India and Persia, may be seen in Regent's Park.

In the first edition of this work, I said, that having heard and read the evidence of such men as $\mathbf{M}$. Boucher de Perthes, Lyell, Prestwich, and Falconer, I should as soon think of believing that Professor Owen was incapable of detecting the difference between the skeleton of a lion and an ass, as of questioning the authority of those geologists respecting the age of the Post-Tertiary deposits, in which the flint implements have been detected, deposits upon which they have expended so much of their time and study, and upon which they have 
brought to bear every expedient of experience and research. I now recommend those who have doubts respecting the great age of those deposits, although they are only Post-Tertiary gravels, to read the amount of evidence collected by Sir C. Lyell, in his work on "The Antiquity of Man," for themselves. I camnot say more here than that man is now proved to have lived in Eng. land and France, during the period known as the ralley gravels, a period when a series of broad rivers flowed much above the present water-flow, and before the present rivers had excarated their beds, when the Glacial period was drawing to a close, but the climate even then was much colder than at present, and the estuaries of our large rivers were probably frozen in the winter, when the gigantic deer, the cave lion, and woolly rhinoceros, with two or three species of elephants, were living.

2. Pachydermata.-Cuvier rauked the Pachyderms, or thick-skinned animals, and the Ruminants as the tro most distinct orders of animals. The later researches of the geologist and palreontologist furnish us with striking illustrations on the aflinities of extinct species to living forms of animals.

Mr. Darmin says, that "the more ancient any form is, the more, as a general rule, it differs from living forms," and "that the extinct forms of life help to fill up the wide intervals between existing genera, families, and orders."

Professor Owen's discoveries obliged him to alter Baron Cuvier's classification of the Ruminants and Pachyderms. Cuvier ranked the pig as a Pachyderm; but Ören discovered so many fossil links, so many intermediate animals, that he was enabled to fill up, as it were, by fine gradations, the apparently wide interval between the pig and the camel, and he tells us that a vast assemblage of species of beasts, nearly all of which have passed away, filled the interval between the Ruminants and Pachyderms, and coexisted in Europe with the now exotic genera of elephant, rhinoceros, and lippopotamus. 
The rhinoceros is a Pachyderm, as also is the tapir.

A living specimen of the rhinoceros (R. unicornis) may be seen in Regent's Park.

The antetype of the rhinoceros was the Palæotherium, a genus which lived during the Eocene epoch, and whose remains are abundant in France. It also inhabited England, and has been found in the Binstead quarries of the Isle of Wight. Like the rhinoceros, the Palæothere frequented the borders of lakes and marshes. Some extinct species of the rhinoceros lived in the Pliocene period, and an extraordinary form of this quadruped inhabited England during the Post-Pliocene epoch. Like the mammoth, it was furmished with a twofold corering of wool and shaggy hair. An entire fossil carcase of this rhinoceros was found by Pallas in frozen soil on the Lena river in Siberia; and its remains have also been disinterred in large quantities near London.

The food of this fossil rhinoceros was partially preserved in the specimen at St. Petersburg, as well as a quantity of the hair and wool. The following particulars are given in a letter to Baron Humboldt, dated 1846:"I have been so fortunate as to extract from cavities in the molar teeth of the Wiljui rhinoceros a small quantity of its half-chewed food, among which were fragments of pine leaves, one half of the seed of a polygonaceous plant, and very minute portions of rood with porous cells were still recognizable." This remarkable animal is named Rhinoceros tichorhinus, or strongly-walled about the nose, in contradistinction to another species of Sonthern Europe called R. leptorhinus, or fine-nosed. Mr. Irugh Strickland, Mr. Jabez Allies, and the Rev. W. Parker obtained many teeth of the rhinoceros from the Bricklehampton and Cropthorne drifts of Worcestersihire.

Sir Charles Lyell mentions in his work on the "Antiquity of Man," that Colonel Wood discovered, in 1861, in the Gower caves, in Glamorganshire, some well shaped flint knives, evidently of human workmanship, associated with the remains of two species of 
rhinoceros, the $R$. tichorinus and $R$. hemitoechus of Dr. Falconer. "It is clear," says Sir Charles, "that man was coeval with these two species;" while from the researches of $M$. Lartet we learn that men devoured the Rhinoceros tichorinus and split the bones to obtain the marrow.

I have to thank Mr. Ballard, the contractor of the Malvern, Worcester, and Hereford Railway, for some fossil bones of the rhinoceros and mammoth, from the Glacial drifts of the Malvern district. There are also some fine heads in MIr. Beard's collection, from Banwell caves, Somerset.

The coner of the Bible is the hyrax of naturalists, and is a diminutive hornless rhinoceros, about the size of a rabbit: it inhabits rocky places in Africa. Ancient as is the coney of Scripture, there was one still older, for a hornless rhinoceros (Acerotherium), or gigantic hyrax, lived in the Miocene period.

The Zoological Society possesses specimens of the American species of tapir.

The tapir is a form of Pachyderm, of which three species are known to be living-the Malay tapir and two American species. Many tapir-like animals, with a short proboscis, lived at the commencement of the Dawn epoch; they appear to have had affinities to the tapir and rhinoceros. The restoration of the tapir-like creature Palæotherium by Baron Cuvier was a wondrous triumph of science.

\section{Order 6.-ANIIMALS WITH A PROBOSCIS. Proboscidea.}

There are two living species of elephants, the Asiatic and African species; they differ in the size of their ears and the structure of their teeth. Thanks to the travelling menagerie and the Zoological Gardens, the majestic aud intelligent elephant is known to every child; but 

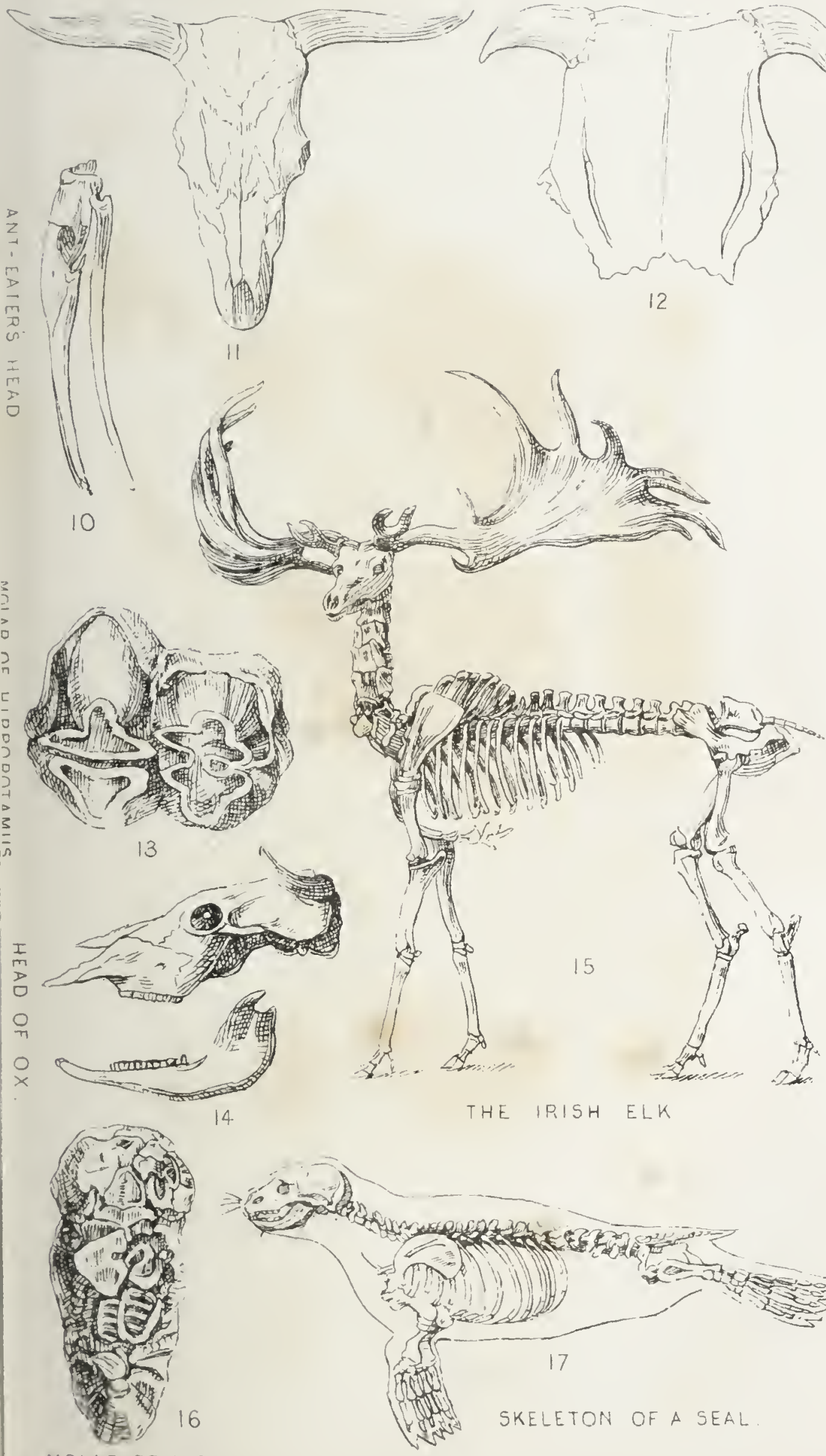

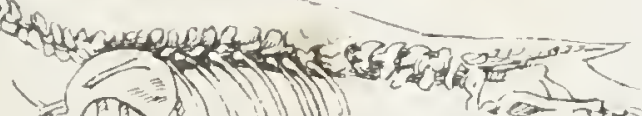



many persons are ignorant of the history of the proboscis-bearing animals of former ages. There is not, I believe, a county in England in which their fossil remains have not been found. At Ramsgate there is a collection of tusks which became entangled in the nets of fishermen off the mouth of the Thames, while near Brighton is an "elephant bed" containing the remains of hundreds of extinct elephants, of every size and age; and we are almost as sure of finding portions of the teeth or bones of the mammoth (E.primigenius) in Post-Pliocene gravel, or drift, as we are of tinding the remains of extinct reptiles in the lias.

Remains of proboscideans of different genera abound in the Tertiary formations of Europe, Asia, and America, from the Miocene to the Post-Pliocene deposits, but an account of their specific distinctions, their range in time, and their geographical distribution is beyond the limit of our space. I must refer roy readers to the contributions of Dr. Falconer in the Quarterly Journal of the Geological Society* for further information.

The Mammoth is probably the latest form of elephant which inhabited these latitudes, and ranged as far north as $60^{\circ}$. So abundant are their remains in Siberia, that large quantities of ivory are supplied from their tusks in these frozen charnel-houses of the far north. The nearly perfect skeleton of one of these beasts is preserved at St. Petersburg. The carcase was found entire in frozen gravel, with its skin clothed with reddish wool, and long black hair, the tusks being nearly ten feet in length; and portions of birch, willow, and fir, which it had devoured before its entombment in its icy grave, were found in its stomach.

Professor Piazzi Smyth informs us that the skeleton of this animal is so gigantic that, when he photographed the monster, the head and shoulders of a stuffed hippopotamus which came into the field of view did not reach up to the knees of the mammoth, and that the tusk of a

* Quart. Jour. Geol. Soc., Nov., 1857, and May, 1858. 
stuffed elephant which also entered into the picture appeared puny indeed beside the war-like weapons of the older animal.**

The Mastodon was a large proboscidean with the feet, tusks, and trunk of the elephant; but the teeth were more like those of the hippopotamus, and the tusks were nearly straight, whereas those of the mammoth are curved. The mastodon inhabited America until a late geological epoch, and probably was contemporary with man. Its remains are found in great numbers in all parts of North America, and more especially at Big-bone Lick, a celebrated morass or bog in Kentucky, about twenty-three miles in a south-west direction from Cincinnati. Imbedded in the blue clay of this ancient creek, the entire skeletons, or separate bones, of not less than 100 mastodons, 20 mammoths, with remains of a species of stag, horse, and bison, have been discovered. Different species of the mastodon once lived in Europe, and the teeth of one ( $M I$. augustidens), tinged with copper and heated, have furnished many a lady fair with the beautiful gem known as the turquoise. The mastodon is the oldest known form of elephantoid animal, one species having been found in strata of Miocene age. Nearly thirty species of mastodon, and elephant, are known to palæontologists. The mammoth appears to have lived both before and after the Glacial epoch; while those who will study the evidence adduced can no longer doubt that men and mammoths lived in the same period. Dr. Falconer described a pigmy species of elephant ( $E$. Metitensis) from Malta, at the meeting of the British Association at Cambridge, which was not larger than a common hog.

It is very likely that Dr. Falconer's researches respecting fossil-proboscideans will enable geologists to characterize certain groups of strata by their elephalltine relics; and also the geographical distribution of ancient lands as compared with the present surface of

* "Three Cities in Russia." 
the earth. We learn from Sir C. Lyell that the teeth of the American mammoth (E. Americanus) are different from those of the European mammoth, and that the American form is a geographical variety; while the African form of the pigmy elephant of Malta leads us to infer that Malta was formerly a part of the African continent. Elephas meridionalis is an elephant that once lived in England, the remains of which are found in the forest and lignite beds of Cromer, in Norfolk, which hare yielded so many mammalian relics to the researches of the Rev. S. G. King and Mr. Gunn. E. meridionalis and Rhinoceros Etruscus are characteristic of these beds. The lignite beds are pre-glacial and are covered up by glacial drift and boulder clay. The vegetation is recent, but the remains of no less than three species of elephants are found associated. Two of these, E. antiquus and E. primigenius, appear to have lived through the Glacial epoch and in post-glacial times were contemporary with man. The E. meridionalis has not, however, yet been proved to have been co-existent witb our race. It may have died out during the Glaccial epoch.

\section{Order 7.-Toxodontia.}

The Toxodon is an extinct genus of South American mammals, three species of which have been found in recent Tertiary deposits. The remains of the toxodon have only been found in South America. It was probably allied to the Sirenia; and judging from the position of its eyes, ears, and nostrils, it was also aquatic. In size it nearly equalled an elephant.

\section{Order 8.-IIERNAID ANIMALS. Sirenia.}

These animals are little known. The name is given to the group from the mermaid appearance that they pre- 
sent when swimming in the water nursing their children, which they hold encircled by one arm. Their appearance, however, out of the water is far from ladylike, as they look very like a seal endeavouring to be developed into an hippopotamus.

Two species of the Manatee are known in America, and one in Africa, and the Dugong is common in Ceylon. The manatee grows to the length of fifteen feet; the dugong occasionally attains to the length of twenty-six feet. They are good for food, and present some peculiar and interesting points of structure. The manatee, when very young, has two rudimentary pointed teeth in the intermaxillary bones, which soon disappear; but in maturity it retains rudimentary nails on its fins. $\mathrm{Mr}$. Darwin's explanation of these rudimentary organs is that disuse has been the main cause of the loss of organs which were once developed; and that it has led in successive generations to the gradual reduction of various organs, as in the case of the manatee; of the eyes of animals inhabiting dark caverns; and the wings of birds inhabiting oceanie islands.**

An arctic form of the Sirenia, - the Rytina, is supposed to have become extinct within the last century. It was a large animal, measuring 25 feet in length and nearly 20 in circumference. It was discovered in the year 1741, on an island in Behring's Straits. Like the great pigeon of the Mauritius, - the dodo, the rytina appears to have been entirely extirpated in a few years by the hand of man.

The Sirenia, though now so small a group of animals, were once very abundant, and widely distributed throughout Europe, especially during the Mriocene epoch.

The great Dinotherium (dreadful beast), a beast furnished with large tusks turned downwards like those of the walrus, but fixed to the lower jaws, possibly belonged to the Sirenia. The entire skull and lower jaws of the dinotherium were discovered in Miocene sand in Ger-

* "Origin of Species," p. 454. 
many. It occurs also in India, in strata of the same age, and was found in Perim Island, in the Gulf of Cambay. This animal inbabited the embouchures of great rivers, and used the enormous tusks of the lower jaw for uprooting aquatic plants on which it fed. The tusk of a dinotherium has been found by Mr. E. Charlesworth, in the Red Crag of Norfolk.

\section{Order 9.-WHALE-FORM ANIMALS. Cetacea.}

The fish-form mammals are aquatic, and some of them are of enormous size and singular form.

The Spermacetic whale (Catodon) has powerful teeth in the lower jaw, as also have the Physeters, but the true whalebone whale (Balcena) has horny plates of whalebone in its mouth and no teeth. It is worthy of note, also, that the young of this whale has teeth before its birth, which, like the nails of the manatee, are rudimentary and come to nothing.

The huge Rorqual is known to attain the length of 120 feet, and an American ship (the Essex) was destroyed by a furious Cachalot. The formation of the Dolphin's brain is so remarkable, and indicates so much intelligence, that the author of the "Vestiges of Creation" fixed on the dolphin as the sea-inhabiting progenitor of the monkey family, and, through the monkeys, of man. The dolphins are of ancient and time-honoured fimily, for three or four species have left their remains in the Iliocene deposits.

I do not know a more wonderful history in all the records of geology than that furnished by the relics of fossil whales. In the Red Crag, a Pliocene deposit in Suffolk and Essex, are found vast numbers of curiouslyshaped stones, which contain a large proportion of phosphate of lime. Thousands of pounds' worth of these phosphates are sold annually; thousands of tons are used in promoting the fertility of the land; and 
thousands of sheep and oxen are fatted upon the turnips and roots which have fed upon the phosphates. And what are, then, those life-giving stones? Many of them are portions of the skeletons, principally the teeth, ribs, vertebræ, and ear-bones, of extinct whales, and sharks, which once inhabited Pliocene seas. Phosphatic deposits are found in the Green sand, and Lias, and, under the name of coprolites, are used as artificial manures. The preserved regetation of primeval forests enhances the majesty of England by the fossil fuel stored in the bosom of the earth; and these phosphatic deposits, first pointed out by the Rev. Professor Henslow, - these relics of whales and other animals long since extinct,- - have been the means of immensely developing agricultural wealth and agricultural produce.

An enormous carnivorous fossil whale, the Zeuglodon (yoke-tooth), has been found whole in Miocene deposits in America. The entire skeleton is 70 feet in length.

A fossil-bone of a whale was found at Tewkesbury in the alluvium of the Severn, and which I presented to the Worcester Museum.

\section{Order 10.-HAND-WINGED ANIMALS. \\ Cheiroptera.}

Mr. Bell, in his work on British Quadrupeds, enumerates nineteen species of hand-winged mammalia or bats.

Bats are divided into two families, the frugivorous, and insectivorous - fruit-eaters, and insect-eaters. The molar teeth of the vegetable-feeders resemble those of the monkeys, and the teeth of the insectivorous bats resemble those of the insectivorous shrews, and moles.

I mentioned that the ringed lemur (Galeopithecus) was formerly arranged with the bats. The Galeopithecus is one of those animals selected by Mr. Darwin, 
in his remarkable work on "The Origin of Species," as furnishing a probable example of an animal in a transition state. Mr. Darwin cannot see any insuperable difficulty in believing it possible that "the membrane-connected fingers and forearm of the Galeopithecus might be greatly lengthened by natural selection; and this, as far as the organs of flight are concerned, would convert it into a bat."

Professor Owen does not range the bat family next to the lemurs. The brain of these animals is much less developed than the brain of the preceding orders of Mammals, having no convolutions, and resembling that of the insect-eaters, in advance of which group Professor Owen has arranged them.

The largest of the bat tribe attains the length of a foot in the size of the body, with an expanse of wing exceeding fire feet. This is the fruit-eating bat, known as the "Flying Fox." Flying foxes (Pteropus) are so abundant in Borneo that Mr. St. John describes them as passing "in tens of thousands," generally flying very high, so as to be nearly out of sight. No frugivorous bats are known fossil, but several insectivorous species have been detected in the later Tertiary deposits. One species is known to have lived in the Dawn or Eocene period.

\section{Order 11.-INSTCT-EATING ANIMALS. \\ Insectivora.}

The molar teeth of these animals are adapted for the crusbing of the insects which they devour, being covered with sharp points. The Shrew mouse would at first sight be ranked with the common mouse, but an examination of the teeth would at once convince the observer that such a classification would be incorrect. The mouse is a rodent, provided with chisel-shaped teeth in front, or gnawers, which in the shrew are altogether 
absent. The greater number of this order of animals burrow in the earth, and hybernate, as the Shrew, Mole, and Desman; but there are insect-eating animals, as the Tupaiia of Sumatra, and the Press, furnished with good eyes, and which live like squirrels in the full light of day. The hedgehog is an insectivore, and a casual inspection of the external features of the hedgehog, and porcupine, would incline us to range these animals in the same order. The arrangement of the teeth, nevertheless, would soon convince us that the hedgehog belongs to the insect-eaters, and the porcupine to the gnawing animals. The bedgehog has representatives in Asia and Africa, and a species called the Tanrec, a native of Madagascar, has the back protected with quills, but does not roll itself into a ball. The earliest known insectivorous mammal is of immense antiquity. I have seen the molars of the Microlestes (little beast of prey) which were detected by my friend Mr. Charles Moore, at Frome, in Somersetshire, in a deposit of the age of the upper New Red sandstone of this country. Amongst existing mammals, the Myrmecobius of Australia has teeth offering the nearest resemblance to these antique fossil teeth; but we learn from Professor Owen, that an extinct marsupial of the Purbeck beds (Upper Oolite), a central secondary group of rocks, afford a still nearer resemblance in the structure of its teeth; and the Microlestes may therefore appertain to the marsupial animals rather than to the insectivores.

An insect-eating mammal, probably not a marsupial, has, however, been detected in the Purbeck rocks, which has been named Spalacotherium, or mole-beast. The family of the insectivores, whether we consider the hedgehog, shrews, or moles, are all represented by extinct fossil genera.*

* See Pictet's Palæontology. 


\section{Order 12.-TOOTHLESS ANIMALS. Edentata.}

This order of animals is divisible into four families, represented by the Sloths, Armadillo, Ant-eaters, and the extinct Megatheroids. They are characterized by the absence of teeth in the front of their jaws, and by the toothless mouths of some animals of the order, as the great ant-eater, whose head tapers to a long, narrow, toothless muzzle.

The sloth is an animal which inhabits the densely intertangled forests of South America, where hundreds of miles may be traversed by passing from one tree to another. The armadillo is confined to South America, as also is the great ant-eater.

In Regent's Park they possess-the hairy armadillo (Dasypus villosus); the six-banded armadillo (Dasypus sexcinctus).

"The armadillos are a purely South American group, of which, in a former geological period, gigantic species inhabited that continent. The activity of their movements; the great rapidity with which they excavate a path into the earth when they wish for retirement; and the perfectly complete protection afforded by their flexible armour, - render the armadillos an object of continual interest to the visitors, when the weather is sufficiently warm to tempt them from their winter repose."

It is not sufficient for the naturalist to know merely the history of the animal forms, and certain peculiarities of structure. It is important to understand the geographical distribution of animals, and to comprehend that in present times peculiar animals are limited to particular portions of the planet's surface. Also that, as a general rule, the fossil animals of the latest geological deposits are found, in all parts of the world, to be closely allied to those animals which are now existing in those regions. The occurrence of the mastodons and of fossil horses in America are exceptions; and we learn that in former ages the New World was geographically more connected with the Old World than at present. 
The sloth, armadillo, and platyrhine monkeys inhabit South America, but nowhere else are they found; nor have fossil remains of any animals referable to their genera ever been discovered in the old world of Asia, Europe, and Africa. The skeletons of enormous animals, allied to the sloth, are found in the later Tertiary deposits of South America. The hind limbs of both the Megatherium and Mylodon were made enormously strong, and the prehensile fore legs also possessed such amazing power, that the auimals were able to uproot and pull down large trees. They occasionally fractured their skulls, when thus engaged, with the falling trees. The bony armour of an extinct gigantic armadillo (Glyptodon) has been found nearly entire in South America, and one large edentate animal (Macrotherium) has been found in the later tertiaries of Europe. This animal, Professor Owen tells us, is allied to the Manis, an old-world form of edentate animal, of which there are four or five species, inhabiting Asia and Africa. We especially recommend the reader to Mr. Darwin's "Naturalist's Voyage," for an account of the extinct edentate animals of the New World.

"The great size of the bones of the Megatheroids, Megalonyx, Scelidotherium, and Mylodon, is truly wonderful." "There are also fossil ant-eaters, armadillos, tapirs, peccaries, guanocos, opossums, and numerous gnawers and monkeys, and other animals; "the extinct species are much more numerous than those now living." Formerly America swarmed with monsters, and now the allied races are mere pigmies when compared with their extinct predecessors. The museum of the College of Surgeons possesses a fine collection of nearly perfect skeletons, to which every student should endeavour to gain access. 



\section{Order 13.-GNAWING ANIMALS. Rodentia.}

Squirrels, marmots, rats, rabbits, hares, hamsters, the beaver, capybara, porcupine, and several other animals similarly organized, belong to the order of gnawers or rodents.

Instead of canine teeth, they have strong chiselshaped teeth in front and molar teeth behind. These teeth are adapted for gnawing. The brain of Rodents is very like that of the insectivores. Rats and mice are well-known examples of this order, and have been transported by man to all parts of the world. They also appear, like man, to possess constitutions adapted to any climate, living as well in the torrid zones as in the far north, or the temperate parts of the world.

In "the struggle for existence," so well delineated by Mr. Darwin, in his "Origin of Species," the rat is mentioned as an example of which one species frequently takes the place of another species under the most different climates.

Mr. F. Buckland, a good authority, believes that the so-called old English rat-the black rat-is not the aboriginal rat of the British soil, but was introduced from France. At all events, the common brown rats have very nearly extirpated the black rats, once so very abundant, by the simple process of devouring their sable brethren.* The Cave rat of America is undoubtedly a striking example of the effect of the use and disuse of bodily organs, as insisted on by $\mathrm{Mr}$. Darwin in the modification of species.

The Cave rat is blind, although the eyes are of immense size; and Mr. Darwin "attributes its loss of vision wholly to disuse." If the rat had never taken to subterranean habits, it would never have lost its eyesight.

Those who have not read Mr. Darwin's work will * Buckland's "Curiosities of Natural History." 
hardly credit that there can be any connection between cats and clover-seed, or that the one should affect the existence of the other. It is interesting, as showing "how complex and unexpected are the checks and relations between organic beings which have to struggle together in the same country." The visits of bees are, " if not indispensable, at least highly beneficial, to the fertilization of our clovers; but humble-bees alone visit the common red clover, as other bees cannot reach the nectar." If humble-bees became extinct, the red clover would become very rare or wholly disappear. Field mice destroy the combs and nests of the humble-bees, and more than two-thirds of their nests are thus destroyed. The number of mice is largely dependent upon the number of cats; and "hence it is quite credible that the presence of a feline animal in large numbers in a district might determine, through the intervention first of mice and then of bees, the frequency of certain flowers in that district."

The common Beaver, well known by the wonderful instinct which it displays, is a rodent. Beavers formerly lived in Great Britain, and were not extinct in Wales until after the time of Oliver Cromwell. I have seen a specimen of a beaver's head and jaw, not fossilized, which was obtained by the late Mr. Hugh Strickland from the alluvial clays of the Thames in Oxfordshire. Many have been found in Cambridgeshire.

In England there lived a gigantic beaver called Trogontherium (gnawing beast), which became extinct before the historical period, and which was contemporary with a Lagomys, a tailless hare, still living in Asia, but extinct in Europe. The remains of this animal, with that of the European beaver, occur below the Glacial drift of the Norfolk coast.

A specimen of the Canadian beaver may be seen in the Zoological Gardens.

Some of the rodents are burrowing animals, and the eyes of these subterranean animals become quite rudimentary in size, and in some cases covered up and 
rendered useless by skin and fur. The Ctenomys of South America is a rodent, and according to Mr. Darwin, "even more subterranean in its habits than a mole."

The Capybara, or Water-Pig, of South America, may be seen inhabiting the Beaver Pond in Regent's Park. This animal is common in the neighbourbood of all the brooks and streams of Brazil and Paraguay, feeding upon marsh and water plants and fruits. It is stated by Dr. Burmeister to be the favourite food of the jaguar, which abounds in similar localities.

Relics of a large fossil Capybara are found in South America.

The Bizcacha (Lagostomus) is an American burrowing rodent very common near Buenos Ayres, and somewhat resembles a rabbit, but with larger guawing teeth, and a long tail; it has only three toes behind, like the agouti. Fossil remains of an extinct bizcacha have been discovered.

In the Zoological Garden is a cage tenanted by a fine pair of the Coypu (Iryopotamus coypus) of South America. They are lively and playful in their habits. They are nearly allied to the Beavers (Castor), of which the Society have quite recently regained a specimen.

The Rodents of America were represented by a gigantic analogue, on that continent, during the later Tertiary periods.

There is a "ground-pig" (Aulacodus), a native of Southern Africa, which appears to be a link between the beavers and the quilled porcupines.

The Society possesses several species of porcupine (Hystrix) and numbers of squirrels, the marmot (Arctomys) the jerboa (Dissus), with other gnawers, may be seen in the small mammalia house.

Professor Owen informs us that no evidence has yet been obtained of any unequivocal remains of a rodent animal in strata more ancient than the Eocene tertialy deposits.

It is interesting to know that animals so familiar to us as our dormice and squirrels were represented in France 
during the Dawn period; and that "the lacustrine marls of the Miocene epoch have yielded evidences of not fewer than eleven genera of rodentia distinct from any now known to exist.

Those who only know the rat and mouse as examples of the order Rodentia will do well to purchase Routledge's "Illustrated Natural History," by the Rev. J. Wood, and thus become acquainted with the extraordinary forms of rodent illustrated and described in this excellent work.

\section{Order 14.-ANIMALS WITH POUCHES. Marsupiatia.}

The pouched animals derive their name from marsupium, a pouch. There appears to be a link between the marsupials and monotremes, and also between the monotremes and birds.

Marsupials are remarkable for the premature production of their young, the young of the kangaroo being only an inch long at their birth, when they are transferred to the pouch. They are divisible into two groups -Flesh-eaters, as the opossum, dasyurus, and tigerwolf (Thylacinus); and Plant-eaters, as the kangaroos, wombat (Phascolomys), and koala, or Australian bear (Phascolarctos).

With the exception of the opossum group of America, the marsupials are confined to Australasia and the islands of the Indian Archipelago. We learn from Sir C. Lyell that Australia supports one hundred and sixty species of marsupials. The comparison of animals peculiar to different zoological regions of the globe is very remarkable in the instance of the marsupialia. We are not surprised that the lion, tiger, and panther of the old world should be represented in the new world by the corresponding forms of the cougar, the jaguar, and the ocelot, or the camel by the llama; but that there should be marsupial forms of carnivores so representative as are the tiger-wolf and Tas- 
manian devil, of non-marsupial carnivores; or as the marsupial rodent (the wombat) is of the non-marsupial rodent, is certainly very remarkable. One cannot doubt that the Australian marsupials represent the great world of other known existing quadrupeds nearly as feebly as the wingless birds, of past ages, in New Kealand, would represent the existing creation of different birds that traverse the air, land, and waters of the globe.

It may seem strange also that marsupials should be confined, or nearly confined to Australasia. Geology, however, steps in and tells us that it was not always so, and that the law of distribution of various classes of mammals was different in other epochs of the earth's history; that edentate animals once lived in Europe, that marsupials were once numerous in Europe, and that England possessed her marsupials ages ago.

In the structure of pouched animals there is an admirable provision for sustaining the pouch and its burden in two supplementary bones, called the marsupial bones; and with respect to these bones and their generic relations, deduced from characters of the lower jaw and teeth, Professor Owen gives a striking example of the truth of the laws of comparative anatomy.

A fossil mammal was discovered in the Eocene tertiary deposits of Paris, and when Cuvier expressed his belief that it was an opossum, from the examination of the teeth and other parts, his associates doubted. "He invited them, therefore, to witness a crucial test. The outline of the back part of the pelvis was exposed, the fore-part buried in the matrix. By his delicate use of the graving tool, Cuvier brought to light the fore-part of the pelvis with the two marsupial bones."* Professor $\mathrm{O}$ wen also had brought to him from New Zealand what was apparently an old marrowbone, about six inches in length and rather more than two inches in thickness, and when he had carefully examined this unpromising fragment, he ventured to prophesy that it not only belonged to a bird, 
but a bird that was unable to fly-a gigantic, wingless bird, far heavier than the ostrich; and prophesied truly. In the Museum of the College of Surgeons stands the skeleton of the Dinornis, and at its feet rests this old bone; and in the Transactions of the Zoological Society for 1839 are the conclusions arrived at on the old bone before the skeleton of the entire bird had arrived in England!

Many remains of marsupials, some of them belonging to gigantic animals, have been found in caves in Australia. They belong to the later tertiary epochs. When in the old world mammoths, rhinoceroses, and hippopotami -in South America gigantic sloths and armadillos-in New Zealand colossal, wingless birds were living-the forms of animal life in Australia were marsupials, and represented by gigantic kangaroos, dasyures, and wombats, rivalling in size the rhinoceros and buffalo. There is in the Worcester Museum a valuable collection of fossil bones of these extinet marsupials, collected by Mr. Hughes and $\mathrm{Mr}$. Isaac, from Darling Downs, in Australia. They have been described by Professor Owen.

MIr. R. F. Tomes has lately described a new American marsupial from Ecuador, in America, which was discovered by Mr. Traser.

The collection of marsupials in the gardens of the Zoological Society of London is unrivalled, and many an hour have we passed in contemplating these ancient forms of Mammalian life.

According to the Guide to the Gardens, the Kangaroo Inclosures contain :- "Bennett's Kangaroo (Halmaturus Bennetti); the Padmelon Kangaroo (H. Thetidis); the Red-necked Kangaroo (H. mficollis; the Great Kangaroo (MLacropus major); the Black-faced Kangaroo (MI. melanops); the Rock Kangaroo (Petrogale penicillata).

"MIr, Gould asserts the excellence of kangaroo venison as a meat for the table; and the introduction of these animals would, thereore, be something more than a mere zoological luxury.

"The great kangaroo is now becoming scarce in the neighbour- 

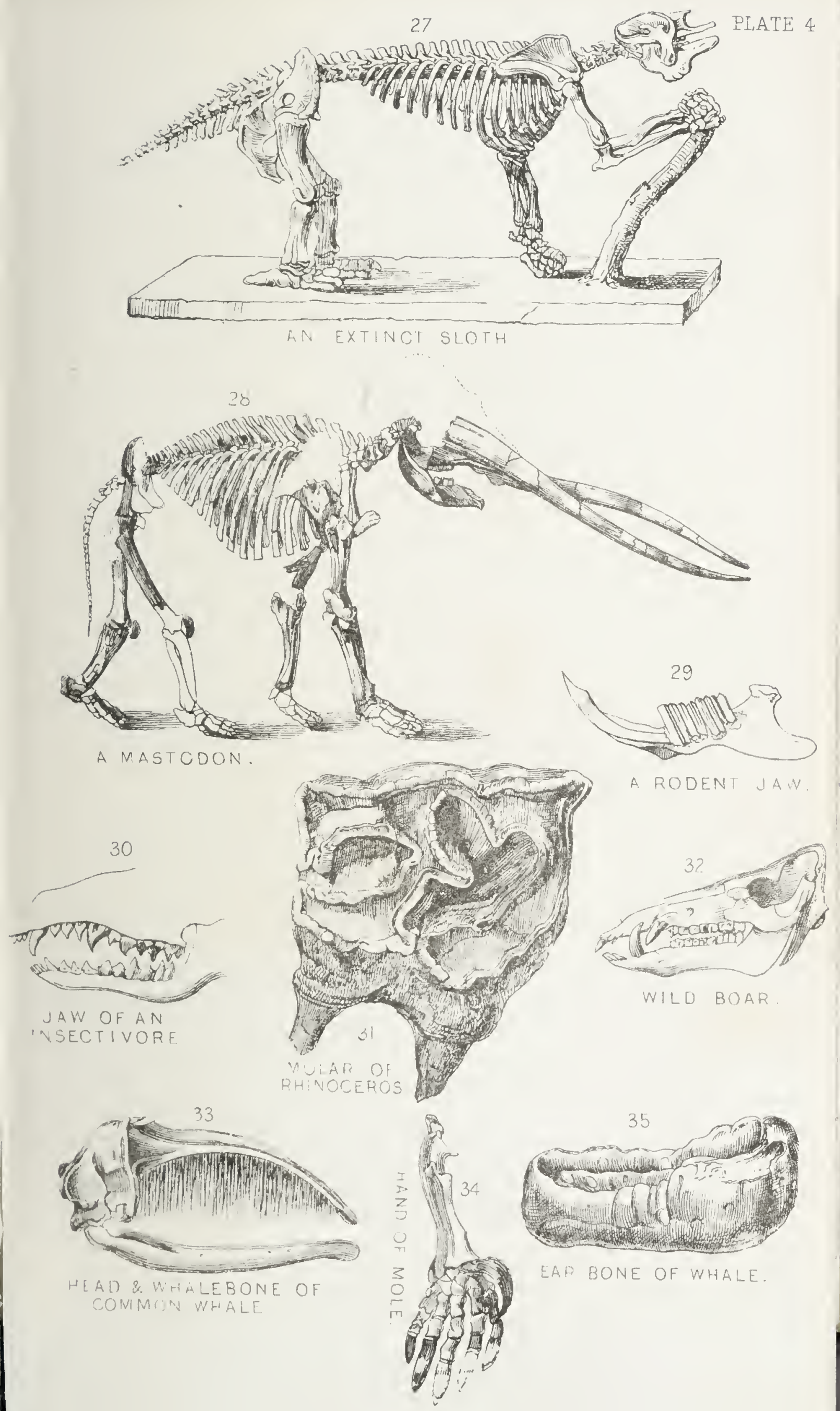

hood of the coast in New South Wales, and specimens seldom reach this country. It breeds, however, with nearly as great facility as the preceding species, and a numerous progeny has in former years been produced at the society's farms at Kingston, at Knowsley, and at Stubton in Lincolnshire."

The Wombat also may be seen in the Gardens, and of this animal it is said :-

"The natural habits of the wombat are nocturnal, and in beautiful accord with its instinct. The present specimens had no sooner been placed in the enclosure than they began to excavate a burrow under the house which had been made for their reception; and in this burrow they for a long time lived, at first showing themselves scarcely at all by day, and only coming out to feed at dusk. The wombats bred here in 1856."

The Society also exhibits specimens of the Ursine Dasyure, or Tasmanian Devil (Dasyurus ursinus); Mauge's Dasyure (D. Mlaugai); the Vulpine Phalanger (Plealangista vulpina); the Kangaroo Rat (Hypsiprymnus murinus); the Tasmanian Bettong (Bettongia cuniculus); the Short-headed Flying Opossum (Belideus Treviceps); the Long-tailed Flying Opossum (B. flaviventris).

These animals all belong to the order of Marsupials, in which the young are born in a rudimentary state and transferred to a pouch situated on the lower part of the abdomen of the female.

In a cage among the birds (Eagle Aviary) is a specimen of the largest carnivorous Marsupial, the Tasmanian Wolf (Thylacinus). It is restricted to Tasmania, and has not been discovered in Australia alive. It is known there as fossil. Every naturalist should see this specimen, as the Thylacine is nearly extinct.

It is probable that the Microlestes of the German and English trias, was an insectivorous marsupial, and also the Dromatherium of the American trias, or lias.

The jaws of flesh-devouring marsupials are known in the oolites of Stonesfield, near Oxford, associated with jaws of regetable-feeding marsupials. 
The Stereognathus appears to have been "a small. vegetable feeding or omnivorous quadruped." My friend, Mr. Ray Lankester, possesses a lower jaw of a new species of this little quadruped from the Stonesfield slate. It appears uncertain whether it is marsupial or placental. In the upper oolite (the Purbeck beds) carnivorous jaws and teeth of marsupials have been detected.

No less than fourteen species, referable to eight or nine genera of diminutive quadrupeds, the largest not exceeding the hedgehog and polecat, are now known from the Purbeck beds. One form Professor Owen considers to be typical of the tiger-wolf of Australia, the Thylacine; Dr. Falconer demurs, and believes the Plagiaulax to have been a herbivorous marsupial. Marsupials existed through all the Tertiary epochs.

\section{Order 15.-Monotremata.}

Only two genera of this singular class are known, the duck-billed Ornithorhynchus and the Echidna, or porcupine ant-eater. The "duck-bills" frequent the Australian rivers, and are called water-moles by the colonists.

The Ornithorhynchus is one of those anomalous forms of animals, which Mr. Darwin declares may be almost called "a living fossil;" that is to say, it is an animal in which, from having been confined to a limited area, and from having been exposed to a less severe struggle, or competition, for existence, there has been less improvement and development of its structure, through selective modification, than in those forms which have had a greater struggle for life.

The Echidna is a burrowing animal, about the size of a hedgehog, furnished with strong spines like the porcupine, a tapering snout, and long flexible tongue. Its food consists of ants and other insects, caught with the 
tongue. It is a representative of the ant-eater's of South America.

The intestines of the Monotremes terminate, as in birds, in a cloaca, and they may be said to be almost egg-producing or oviparous beasts. They possess marsupial bones, but no marsupial pouch. The teeth are rudimentary, and altogether they appear to constitute a link between the marsupials and birds. These animals have not as yet been discorered in a fossil state. 


\section{CHAPTER II.}

\section{Class II.-BIR D S. Ares.}

BInds are oviparous (egg-producing) vertebrated animals. Their skeleton is composed of nearly the same elements as in mammals, but their bones are lighter and contain more earthy matter, and are capable of being filled with air. Birds possess a wonderful double and complete circulation, with a larger amount of innate animal heat than mammals. Many birds are thus enabled to exist in the regions of ice and snow. The vision of birds is, among all living creatures, the most piercing and distinct, and therefore, as far as we linow, they are examples of the most perfect adaptation of sight.

So swift are some birds upon the wing, that they exceed our utmost railroad speed in velocity; while so exquisite are the harmonious powers of others, that eren woman, with "her silver tongue," cannot match their melody. Who can behold the gorgeous plumage of the birds of the tropies, the jewelled apparel of the hummingbirds, the magnificence of the peacock, or the modest elegance of the dove, without acknowledging that the Creator has fashioned them "beautiful exceedingly," and has bestowed upon birds wonderful gifts of intelligence, melody, beauty, power, and speed.

The individual who can pass unmoved through a collection of birds, living or dead, is unlikely to take much interest in other branches of Natural History.

"A primrose by the water-brim, A yellow primrose is to him, And it is nothing more." 

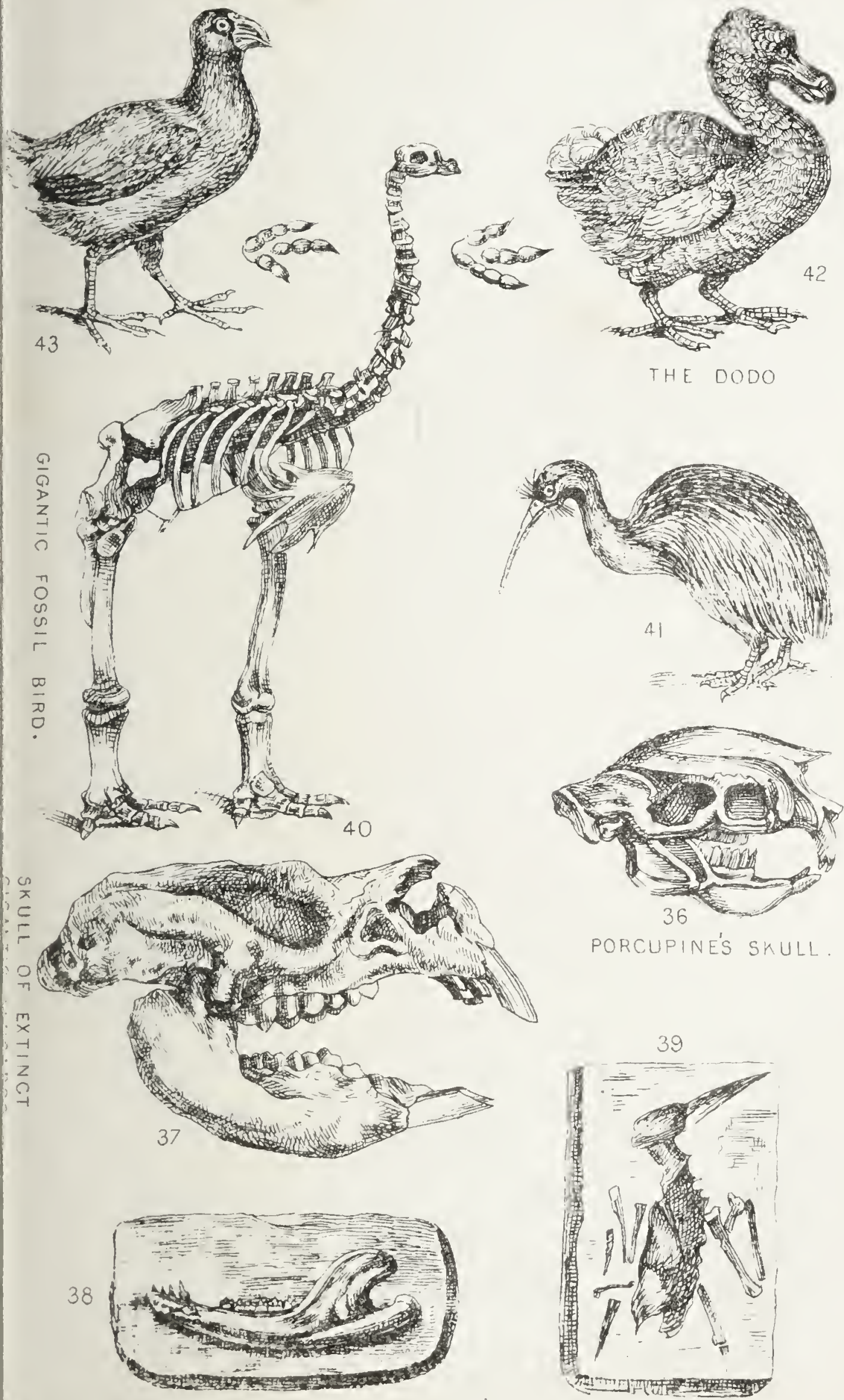

FOSSIL JAW OF SMALL MARSUPIAL. 

Birds are arranged in Orders, according to their structure, their distinguishing characters being chiefly taken from the formation of their legs, feet, bills, and chest-bone or sternum.

Order 1. Ravexers or Seizers (Raptores)-vulture, eagle, hawk, owl.

2. Cumblins (Sccunsores) - woodpecker, wryneck, parrots, toucans.

3. Sparrow-tike Birds (Passercs)-blackbird, linnet, swallow, sparrow, crow.

4. Pigeons (Columba)-piseon, dove, dodo.

5. Pourtir (Gallina) - common fowl, pheasnnt, grouse, peacock.

C. Runvers (Cursores) - ostrich, emu, bustard, apteryx, dinornis.

7. Waders (Grallatores)-crane, heron, plover, rail, snipe.

8. Swimming-Footed (Palmipedes) - divers, petrel, duck, albatross, swan.

Order 1.-RAVENERS, OP RAPACIOUS BIRDS. Raptores.

The combined powers of flight, sight, and grasp, distinguish the rapacious birds from all others. They may be recognized by their hooked beaks and talons.

They constitute two families - the Diurnal, as the vultures and hawks; and the Nocturnal, as the owls.

The great Condor of the Andes (Vultur gryphus, Lin.) soars aloft, a living balloon, far above the lightest cloud, in a region so intensely cold, that were it not for the wondrous porrer it possesses of developing heat within its frame, it must become as adamantine as the mountainpeak above which it floats. The lammergeyer is one of the largest birds of prey of the old world. Its extent of wing sometimes reaches ten feet; and this powerful vulture has been known to hurl men and animals over 
the side of a precipice with a single stroke of its wing. In England, the Raptores are becoming extremely rare; even the sparrow-hawk (Accipitor nisus) is a rare bird.

No birds of the vulture tribe are found in Australia, where the absence of indigenous quadrupeds larger than the kangaroos indicates that they could not be supported on carrion. A specimen of a white hawk, sent to England, was, we have understood, the cause of Mr. Gould's visit to Australia, where he collected the materials for the most celebrated of his unsurpassed works.*

The Secretary bird (Secretarius reptitivorus), which possesses legs as long as a wader, is an example of the modification of structure in birds of prey. It is an inhabitant of tropical Africa, and pursues on foot the reptiles which constitute its food.

Again Jardine's Harrier (Circus Jardinii), so named by Mr. Gould, in honour of the distinguished naturalist, Sir W. Jardine, is a very remarkable Australian hawk which looks as if it was developing into a Secretary bird. It is never seen to soar, but flies rery low, and like the secretary hunts reptiles.

The Chanting falcon of Africa is another anomalous raptor, for instead of the disagreeable sounds uttered by the raptores in general, whether owl, vulture, eagle, or falcon, the Chanter (INelierax musicus) warbles notes, which have been compared to the sounds of musical glasses.

In Regent's Park the engles, harpies, kites, vultures, and owls, have all their aviaries; and the variations of structure in the birds may be easily studied.

If the first found mammal is small, the "Brontozoum" was a giant among birds: and so well are some of its footsteps preserved, that "the papillose and striated characters of the integument covering the cushions on the under side of the foot" are impressed upon the ancient mud. From the absence of teeth in birds, it is

"Gould's "Birds of Australia." 
often difficult to determine their relations; but it is probable that the birds which left their footprints on the Connecticut sandstones (now believed to be of Oolitic age), were more nearly related to the waders and aquatic birds than to the raveners, or seizures.

The generic term Lithornis (petrified bird) is applied by Professor Owen to the fossil relics of a small vulture found in the Eocene clay of the Isle of Sheppey. He also informs us, that the birds of prey were represented by species "the size of our ospreys, buzzards, and smaller falcons, and, most probably, also by an owl."

Portions of the skeletons of a vulture and a species of eagle or osprey have been found in Miocene freshwater deposits, in France, in which beds fossil eggs, and the impressions of feathers have also been discovered.

Fossil feathers are found in the upper Oolites of Germany.

The bone-caverns, which are great fissures in lime-stone rocks, formerly the resort of wild animals, have furnished remains closely resembling the falcon, the sparrow-hawk, and one or two species of owl.

\section{Order 2.-CLIMBING BIRDS. Scansores.}

The Climbers have their feet adapted for climbing, two toes being directed forwards and two backwards. There are, however, several birds that climb, the toes of which are like those of the Perchers, three before and one behind, as the tree-creepers and nuthatches. The curious honey guides, the talking parrot, the enormouslybeaked toucan, the various species of woodpecker, the wryneck, and the cuckoo, are arranged in this division.

Mr. Darwin mentions a remarkable instance of the chauge of habits as regards a bird of the woodpecker tribe. On the immense plains of La Plata, where not a tree grows, there is a woodpecker which never climbed a 
tree, but which, " in every essential part of its organization, its colouring, the harsh tone of its voice, and undulatory fiight," is a true woodpecker.

The collection of parrots in Regent's Park is rery rich; there are upwards of eighty species now living in the "Parrot House," from Hindostan, Java and Sumatra, Australia, Madagascar, Africa, and North and South America. Among them are also the toucan (Ramphastus). The beautiful grass parakeets are in the "New Aviary;" and here again we have an example of difference of habits in the Climbers. We learn from Dr. Sclater that the grass parakeets "for the most part inhabit the plains of the South, living almost entirely on the ground, and feeding on the seeds of grasses. At certain periods of the year they migrate in vast flocks, their line being apparently determined by the scarcity or abundance of food afforded by the localities they visit. Their flight is excessively graceful; and as the tail is generally expanded in rising, the brilliant colours of the side-feathers of that organ in the Turquoisine make a most striking and attractive display."

The Owl parrot (Strigops) is a very singular bird, partaking, as its name implies, of the characters of the parrot and the owl. It is nocturnal, and conceals itself during the day time in holes under trees, wearing regular paths near its nest and habitation.

A very remarkable genus of long-billed parrots (Nestor hypopolius) is restricted to New Zealand and Norfolk. Island. Another species (N. productus), now extinct, was found living in Philip Island-so small an island, that it is only five miles in extent. So restricted was this bird, that Mr. Gould observes that persons, who hare resided in Norfolk Island many years, assured him its occurrence there was totally unknown, although the distance from one island to another is not more than three or four miles. Mr. Walter Mantell discovered the fossil bones of a Nestor in alluvial soil on the Western shore of the north island of New Zealand. This peculiar parrot is, therefore, of antique origin. 
The cuckoos constitute a large family, containing many species, among which the Ground cuckoos of South America, the Rain bird of Jamaica, and the Cow bird (Coccygus) of America are ranked as allies of our European Cuculus canorus, so celebrated for its mell-known, and mell-lored call, and for its unnatural parental conduct. Mr. Darwin believes that our cuckoo's strange instinct of laying her eggs in other birds' nests has been generated; and his argument on the possibility of modifying instinct in a state of nature by selection, is worthy of the comsideration of all naturalists. I am not aware that any other cuckoo follows the example of our European species. It has been asserted that the American cuckioo occasionally lays in the nests of other birds, but I understand the assertion is without foundation.

In the Dawn (Eocene) epoch, the Climbers were represented by species as large as the cuckoo and kingfisher, and a woodpecker has been found in Post-Pliocene deposits.

\section{Order 3.-PERCHING BIRDS. Passeres.}

This is the most numerous order of the class Birds, and also the most perplexing, for it is difficult to imagine that the sparrow, shrike, crow, bird of Paradise, and the rhinoceros hornbill (Calao) belong to the same order. Yet we learn that the gradation from one genus to another is, in some instances, so insensible, that it is extremely difficult to establish subdivisions.

The toes are formed for perching, and the warblers have a complicated larynx.

This order includes all the birds of song, as the nightingale, lark, wood thrush, and mocking-bird; and most of the birds of passage, as the swallow, swift, and martin.

If we should hesitate to rank the secretary-bird, which courses after reptiles, among the rapacious birds, we 
nevertheless find that some of the Perchers affect equally anomalous habits. The tree creeper (Certhia) and the nuthatch (Sitta) possess the habits of wood-pecker's, and are commonly supposed to belong to the order of the Climbers; but they are true passerine birds; as also is the water ouzel (Cinclus), which has been denominated by Mr. Darwin a diving thrush. We learn, however, from Sir W. Jardine, that Cinclus does not belong to the thrushes. Indeed the water ouzel, in its shape, approximates more to the breves, and ant thrushes, than to the mocking bird, or our melodious throstles.

The Galapagos islands furnish a most singular group of finches, quite peculiar to those islands, examples of which I have had the opportunity of seeing in the museum of Sir W. Jardine. How these finches happen to be found nowhere else in the wide world is at present a puzzle to ornithologists. One or two of the species might pass for black hawfinches.

The Shrikes were associated by many naturalists with the birds of prey, from their strong hooked bills and sanguinary habits. I have myself seen the red-backed shrike (Lanius collurio) strike a redbreast on the wing and then proceed to impale its prey upon a thorn. The great shrike ( $L$. excubitor) has on several occasions been killed in Worcestershire, and has been known to breed in Wyre Forest. I saw this bird in the Longdou Marshes during the hard winter of 1855 : it was among a flock of Fieldfares.

The Golden Oriole (Oriolus) is a very rare British bird of this order. We have it, however, occasionally in Worcestershire, among the cherry orchards, and one specimen has been killed within the last ten years, which is now in the Worcester Museum.

I have the authority of my friend, the Rer. G. C. Davies, of Tewkesbury, for stating that the golden oriole has been known to breed in England within the last few years. The locality was Word Minnis, in Kent. The parent birds selected a solitary, swampy place, and built a skilfully-constructed nest among some alder bushes. 
Mr. Davies saw the old birds with their nest, and nearly fledged young, in the possession of a shoemaker.

The ring ouzel (Turdus torquatus) visits Malvern periodically, and I have been informed by my friend, the Rer. Mr. Thorn, an accurate ornithologist, resident in the neighbourhood, that it returns in autumn to feast upon the ripening berries of the mountain ash. It is not uncommon among the woods and hills of South Wales.

In the New Aviary in Regent's Park are many interesting specimens of birds of this order. There may be seen the mocking-bird of America, so remarkable for its power of imitating any sound; the migratory thrush or Americau robin, the golden oriole, the redwing, fieldfare, and ring ouzel, the hawfinch, nightingale, with many other of the Perchers.

Fossil remains of birds, apparently allied to the nuthatch and lark, have been found in strata of the Dawn epoch. A thrush (Turdus) warbled in the woods of the Miocene tertiaries; and birds closely resembling the swallow, thrush, goatsucker, and crow, have left their skeletons in the Pleistocene deposits that contain the remains of the extinct mammals of ancient England.** I refer my readers to Mr. Mackie's contribution on "fossil birds" in the "Popular Science Review."

\section{Order 4.-PIGEONS. Columbe.}

Pigeons have been considered by some authors as constituting a passage from the Gallinæ, or poultry, to the Passerinæ, or perchers.

The crowned pigeon of the Indian Archipelago (Columba coronata) and the Nicobar pigeon (C. nicobarica) approximate the poultry. The former is bred in the poultry-yards of Java, and almost equals the Turkey in size.

* See Owen's Palæontology, p. 291; and Pictet's Palreontology. 
Gnathodon strigirostris is a remarkable form of a frugivorous pigeon, which has probably become extinct within a few years. It was formerly abundant in the Samoan Island, in the Pacific, one of the Navigator group, and was exceedingly tame. Cats were let loose upon the island, and the birds are now destroyed. Sir William Jardine is in possession of the only specimen known, save one in America; the specimens procured by the North American expedition being lost at the wreck of the exploring vessel.

The Gnathodon, or Toothed jawed, also received the name of Didunculus from its relationship to the Dodo, and Solitaire or Pezophaps. It is a thousand pities that naturalists cannot look forward to examining an embryonic Gnathodon, in order to see whether it possessed the rudimentary teeth that some naturalists say may be detected in the beaks of certain other embryonic birds.*

Two centuries ago, the small volcanic islands of Mauritius, Rodriguez, and Bourbon were inbabited by different species of birds with wings so undeveloped that they were unable to fly. Mauritius is an island, forty miles in length, to the east of Madagascar, in the Indian Ocean, and one hundred miles from the nearest land. When discovered, it was clothed by dense forests of palms and various other trees; and when the Dutch, under Wibrant de Wanwick, took possession, in 1598, they found in the island a variety of pigeons, paroquets, and the remarkable "colossal, brevipennate, fungiverous pigeon," the dodo. We must refer our readers to the splendid work of Strickland and Melville for the historical and anatomical data respecting this strange bird. $f$

"As the Greenland whale," says Mr. Strickland, "may be called a permanent suckling, the teeth never penetrating the gums, though in youth they are distinctly traceable in the dental groove of the jaws; as the Proteus is

* It appears that this bird is not yet quite extinct, for $\mathrm{Mr}$. Williams, H. M. Consul at the Navigator Islands, has obtained a living specimen. "The Parthenon," May 2, 1863.

$\uparrow$ The Dodo and its Kindred. 
a permanent tadpole, the dodo was a permanent nestling, clothed with down instead of feathers, and with the wings and tail so short and feeble, to be utterly unsubservient for flight. . . . We cannot form a better idea of it than by imagining a young duck or gosling enlarged to the dimensions of a swan."

The dodo was at first believed to belong to the Ostrich family; and Professor Owen was in favour of its affinity, though in an extremely modified form, to the vulture; while it remained for Professor Reinhardt of Copenhagen, Strickland, and Melville, to determine its proper position "as a very aberrant member of the family Columbidæ;" and as being distantly allied to the ground pigeon (Gourinc), some of which resemble partridges in their mode of life; and again, to the Trerons, which feed on large fruits and berries, and have strong arched beaks resembling those of the vulture. The Pezophaps (a pedestrian pigeon) was living in the island of Rodriguez in 1651, and the highly interesting account of the various productions of the island by François Leguat, who was the commander of a party of French Protestant refugees who settled there in that year, is quoted by $M_{r}$. Strickland. Bones of the pezophaps are preserved at Paris and at Glasgow, and Dr. Melville was enabled to determine that this bird, like the dodo, belonged to a subfamily of the Columbidæ; and was, in short, a terrestrial, flightless, modified pigeon.

It is highly probable that in former geological ages larger islands, or a continent, occupied the geographical position where now Tromelin, Albatross, Rodriguez, Mauritius, and Bourbon islands remain as mere fragments; and that these wingless birds are, or rather were, the relics of animal life of that continent.

It is difficult to account, in any other way, for such restricted conditions of peculiar animals to such diminutive areas.

It may be said that the dodo may have been created especially for the Mauritius island; the pezophaps for Rodriguez (an island only fifteen miles long by six 
broad), and the marine lizard, and black finches, for the Galapagos (for, whether restricted or not, they have not hitherto been found elsewhere); but when we remember the recent history of the Rytina, confined to its island in Behring's Straits, and compare this with the known fact that this animal, or its allies, were once abundant throughout Europe; when we find that the same species of wingless birds of New Zealand are found on separate islands; I believe that it is more probable that these animals owe their restricted and peculiar positions to geographical and geological changes and conditions, rather than to their having been created for localities so restricted as Rodriguez, Mauritius, and the Galapagos. The comparative anatomist is the best judge as to the possibility of "disuse" becoming so wonderful an agent in the change of form as Mr. Darwin believes possible.

The variation of pigeons under domestication, as referred to by Mr. Darwin, is well worthy of earnest consideration.

Ornithologists are agreed that the numerous and welldefined breeds of domestic pigeons are descended from the common Rock pigeon (Columbia livia), a bird which, in the wild state, builds principally in sea cliffs. The Tumblers, Runts, Barbs, and Fantails, have been produced from one and the same wild species, through man's selection of pigeons with large crops, broad tails, or ruffled necks, and by close breeding.

The extraordinary number of pigeons, and their allies, may be best understood by the examination of the different forms in the British Museum. There are some beautiful living birds at the gardens of the Zoological Society, and among them the celebrated passenger pigeon (Ectopistes migratorius).

The following is Mr. Audubon's account of the marvellous numbers of these birds in America :-

"The air was literally filled with pigeons. The light of the noonday was obscured as by an eclipse. Before sunset I reached Louisville, distant from Hardensburgh fifty-five miles. The pigeons were still passing in undiminished numbers, and continued to do so 
for three days in succession. . . Let us take a column of one mile in breadth, which is far below the average size, and suppose it passing over us at the rate of one mile per minute. This will give a parallelogram of 180 miles by 1 , covering 180 square miles; and allowing two pigeons to the square yard, we have $1,115,136,000$ pigeons in one flock; and as every pigeon consumes fully half a pint per day, the quantity required to feed such a flock must be 8,712,000 bushels per day."

This bird, and the following, are in the New Aviary: the wonga-wonga pigeon (Iencosarcia picata), the bronze-wing pigeon (Phaps chalcoptera), and the bush bronze-wing (Phaps elegans). There are also specimens of the magnificent Victoria crowned pigeon (Goura coronata) of the Indian Archipelago.

Twenty-one species of pigeons have been figured by Mr. Gould from Australia.

We learn from Professor Jukes, that a true pigeon is found in Post-Pliocene deposits; and it appears that more are known from older beds.*

\section{Order 5.-POULTRY. Gallina.}

This order is named after the domestic cock, Gallus. Short wings, a bony chest-bone, and a heavy carriage, are the usual characteristics of the birds of this family, some of which are also remarkable for their gorgeous plumage. The majority of game birds belong to the Gallinæ. Several species of wild poultry are known; and one from Java is, we are informed by Sir W. Jardine, the original of our bantams. The Argo fowl (Phasianus giganteus) is a native of Sumatra: this bird has been seen tall enough to peck from off' a common dining-table.

The Curassows ( Crax) are turkey-like birds of America, which live in the woods, feed on fruit, perch on trees, and are easily domesticated.

* Jukes's "Mrnual of Geolngry," and Pictet's Palæontology. 
The common Turkey was brought, not from Turkey, as is generally supposed, but from North America, in the sixteenth century. The Pea-fowl was introduced into Europe from the Ganges; and the Pintado, or Guineafowl, is indigenous to Africa.

In the Worcester Museum there is a remarkable bybrid between the pintado and the hen pea-fowl.

There are many varieties of the Pheasant; and this bird has always been quoted as an instance of species breeding in a wild state.

A Nepaulese pheasant is described by Dr. Hooker as liring among the precipices of the Himalayas, at the beight of 15,000 feet. Ph. Reevesii, from China, is a magnificent bird, with a tail six feet in length.

The common Red Grouse of sportsmen (Lagopus Scoticus) has long been supposed to be restricted, as a species, to Great Britain; yet we have heard the eminent ornithologist, Sir William Jardine, declare that the willow grouse (L. saliceti) of Norway, and the red grouse of Britain, are one and the same species, the habits being adapted to a different climate and different circumstances. There is in the Worcester Museum, a specimen of a hybrid between the black-cock (Tetrao tetrix) and the hen-pheasant. The black grouse is not yet quite extinct in Wyre Forest, and stray specimens have been killed in different parts of the county.

The lover of birds may enjoy a treat among the living Gallinæ in the gardens of the Zoological Society, with the guide-book in hand, which gives a description of the most remarkable birds. The curassows are in the old Aviary, and have bred in England. The pheasant and pea.fowl have an aviary; the gorgeous monal is in tho Impeyan pheasants' inclosure; and the strange talegalla, or brush-turkey, which we apprehend is not a turkey, possesses an inclosure. Of this bird, the Guide says :-

"In the whole economy of the class of birds there is nothing more remarkable than the reproduction of the family to which the Talegalla, or, as the Australian colonists call it, the Bush-Turkey, belongs. Instead of hatching their eggs by incubation in a nest, 


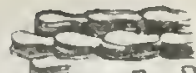

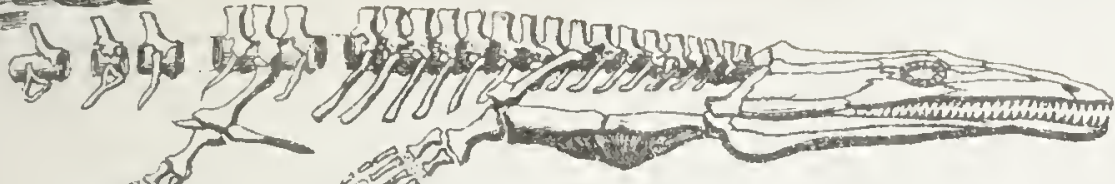

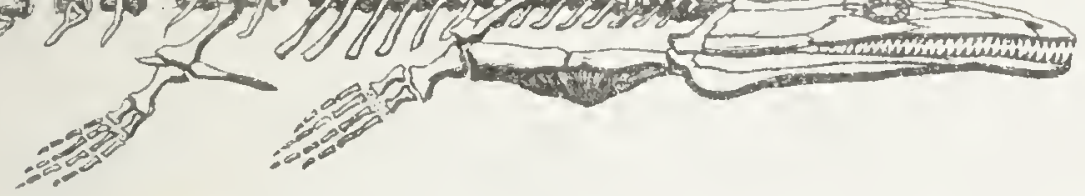

ANCIENT REPTILE FROM THE COAL:
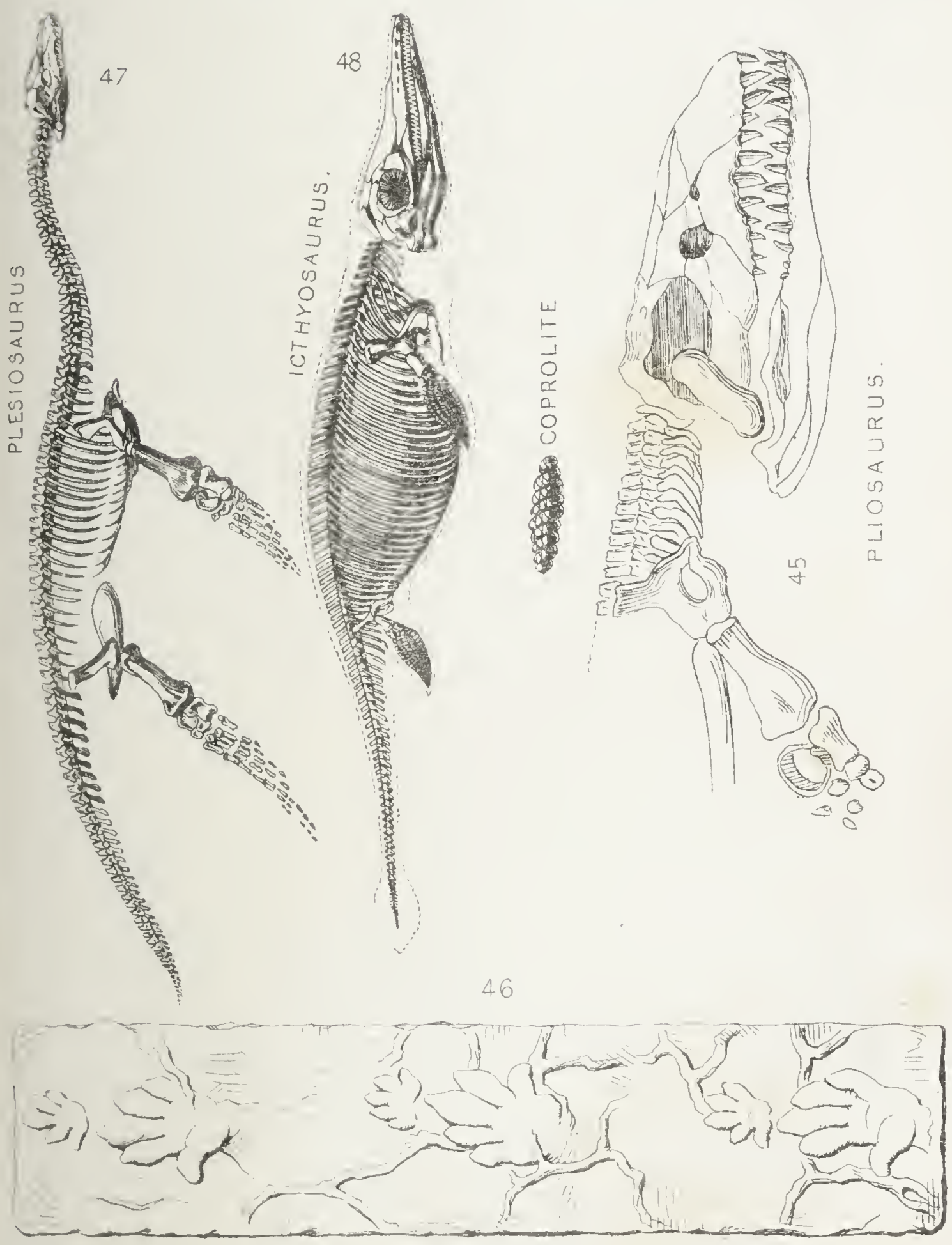

the whole of these birds, as far as their habits are yet known, construct a mound of earth, leaves, grass, sand, or other materials capable of generating and retaining heat, in which the eggs are buried by the birds and carefully watched until the young birds are matured and issue forth from the 'eccaleotion' of Nature, stout, strong, and so fully feathered as to be capable of flight on the third day of their existence."

This appears to be the place to call attention to the remarkable fossil bird, Archæopteryx macrurus, Owen, lately found in a rock, of the age of the Upper Oolite, near Solenhofen in Bararia. This fossil was at first believed to be a feathered reptile, or an animal intermediate between a reptile and a bird. Professor Owen, however, declares it to be a true bird, notwithstanding its peculiar tail, which is like that of a reptile, or rather that of an embryonic rook, which has its caudal vertebræ distiuct before anchylosis has taken place. The wings resemble those of a Gallinaceous bird, its foot is raptorial.

The American partridge, the colin, and the Californian colin with the sand-grouse (Pterocles), are in the New Aviary. A species of partridge is known in the Miocene deposits, and relics of several gallinaceous birds in PostPliocene clays and caves.

\section{Order 6.-COURSERS, or RUNNING BIRDS.}

\section{Cursores.}

The Coursers appear to have numerous affinities with the Gallinæ. The muscles of the thighs and legs are of great thickness, and their sternum is a simple buckler, without the ridge which exists in all other birds. They want the back toe, and the wings are not fully developed.

The Ostrich (Struthio) is a well-known bird, and in the sandy deserts of Africa attains the height of six feet and a balf. 
The ostrich is found only in Africa; and so swift is this Courser, that few animals can orertake it. The American ostrich (Rhea), of which there are two species, is not more than half the size of the African species. The Emeus of New Holland represent the ostriches of the Old World, and the rheas of America. The cassowaries are found in the Moluccas.

The Mooruk (Casuarius Bennetti), is the most recent addition to our knowledge of this family, and as such, is an object of peculiar interest. It was discovered in the island of New Britain, by Captain Deolin, and after two unsuccessful attempts, the living bird now in the Regent's Park was taken by him to Sydney in the autumn of 1857 .

The ostrich and bustard (Otis tarda) are selected by Mr. Darwin as ideal examples of the probable effect of the use and disuse of different bodily organs. He belieres that the early progenitor of the ostrich had habits like those of a bustard, and that, as natural selection increased, in many successive generations, the size and weight of its body, its legs were used more and its wings less, until they became incapable of flight.

The geological history of some birds of the Courser order is very remarkable. The three islands of New Zealand appear, from the researches of geologists, to have been formerly united, and have formed one island, which was inhabited, in the later Tertiary epochs, by a number of gigantic wingless birds, whose remains are now found fossil in the three islands, which must have once formed continuous land, as wingless birds are incapable of traversing across the sea. No indigenous mammals, save two bats, are known (a rat, supposed to be indigenous, was probably imported), and none have been found fossil.

The Apteryx, a singular bird, with the wings rudimentary, terminating in a little hook, and entirely obscured by the feathers, was first brought to England from New Lealand in 1812. Two species of apteryx are known as fossils. The living apertex is nocturnal, 
burrowing in habits, and inhabiting densely-rooded districts. Three species at least are known.

Some rery extraordinary birds, allied to the ostrich order, formerly existed in New Zealand, and were the contemporaries of man, at no very remote period. These birds, we are informed by Professor Owen, resembled the apteryx; but some of them were so gigantic, that the tibia of the leg-bones of one species (Dinornis giganteus) measures upwards of a yard in length. The toe-bones of another (Dinomis clephantopus) "rival those of the elephant." The bones of some of the species indicate birds of upwards of ten feet in height. Well might they be called terrific! Mr. Walter Mantell has discovered remains of the eggs of the dinornis. The eggs were much larger than those of the ostrich.

The Palapteryx (ancient-wingless) was, as its name signifies, another of these large wingless birds, a giant apteryx, known only in a fossil state.

Investigations in Madagascar seem likely to furnish some astounding discoveries respecting birds of this order. The captain of a vessel trading to Madagascar one day observed a native using a vase which much resembled an egg, and, upon examination, proved to be one. The native eventually procured some enormous fossil eggs from the interior of the island, and some fossil bones of a bird. The largest of these eggs is equal in bulk to six ostrich eggs, or $148 \mathrm{eggs}$ of the common hen, and will hold two gallons of water. M. St. Hilaire, who described these marvellous eggs and bones in a report to the French Académie des Sciences proposed the name of "Epiornis" for the monster bird that laid the monster eggs.

The Ostrich-house in the Gardens in Regent's Park contains: the Ostrich (Struthio camelus), the Rhea (Rhea Americana), Darwin's Rhea (Rhea Darwini), the Emeu (Dromaus Nove-Hollandic), the Cassowary (Casuarius galeatus), the Moorus (Casuarius Bennetti), and the Apterys. 


\section{Order 7.-WADING BIRDS. Grallatores.}

The Great Bustard (Otis tarda) is the largest of European birds, and was formerly abundant in Great Britain. A noble pair of these birds, captured in Norfolk, were presented some years ago to the Museum at Worcester by Lord Lyttelton; and about four years since, a male bustard was shot on the Wiltshire Dorns, in full plumage. The bustard, nevertheless, may now be considered extinct in England.

Dr. Sclater informs me that he considers the bustard more nearly allied to the Waders than the Coursers.

Specimens of the bustard may be seen in the New Aviary. The Guide remarks:-

"The Bustards are one of the most striking and well-distinguished families of the Old World. They number about twentythree species, of which three are European, three Indian, one Australian, and fifteen indigenous to Africa. The Houbaras are found in South-Western Europe, Africa, and India; the Little Bustard in Europe and Africa ; the Great Bustard in Europe and Asia. They are extremely majestic in their carriage, even the smaller species having a certain stateliness."

Many of the birds of this order are remarkable for the length of their legs, some of them looking as if they walked on stilts; as the Heron, and more especially the Stilt-bird (Charadrius himantopus). The legs of many of the family are adapted for wading in shallow water, and some, as the Jacana of America, have long toes, especially adapted for walking on the floating leaves of aquatic plants. The common heron, curlew, noodcock, coot, and rail, are familiar examples of the Waders.

In Regent's Park there is the Waders' Inclosure. In this inclosure there are always to be found a collection of Wading birds, which includes the Godwit (Limosa agocephala and L. Lapponica); the Spoonbill (Platalea leucorodia); the Avocet (Recurvirostra avocetto); the Ruff (Machetes pugnax); the Knot (Tringa canutus); the 
Whimbrel (Numenius phoopus); the Curlew (Numenius arquatus); the Oyster-Catcher (Hamatopus ostralegus); the Coot (Fulica atra); the Crested Coot (Fulica cristata), and several European species.

The Crane Inclosure contains several species of cranes and storks. Three species of the Ibis are in the New Aviary; as are also the Australian Porphyrio (Porphyrio melanotus), and the Weka Rail (Ocydromus australis), to which the geologist will pay especial attention, as the probably extinct notornis of $\mathrm{New}$ Zealand is allied to the porphyrio, and the Weka rail follows the fashion of the wingless birds in structure.

The Island-hen of Tristan d'Acunha, an oceanic island, which is very like our common pond Moor-hen, but incapable of flight, is now living in the Zoological Gardens, and is probably one of the last existing specimens of a rapidly expiring race. The Cariama also $(C$. cristat( $)$, is particularly worthy of note; and is thus described by Dr. Sclater :-

"This singular bird is a native of South America. It is considered by naturalists to belong to the Grallatorial or Wading Birds, and is generally placed near to or among the herons. Its habits, as well as its aspect at first sight, bear a striking resemblance to those of the Secretary bird of Africa. The cry of the Cariama is loud, long, and shriil, made up of rapidly reiterated notes which may be heard at a great distance, especially when it first greets the sun on a summer morning."

Fossil bones of a bird of the Rail family were found by Mr. Walter Mantell, in 1847, associated with the relics of the dinornis; and a specimen of this "swamp hen" (Notornis MIantelli) was captured alive in a remote and unfrequented part of the Middle island of $\mathrm{New}$ Zealand, in 1850. So little was known of this bird even to the natives, that, when the skin was shown them by Mr. Walter Mantell, who obtained a specimen from some whalers, they declared they had never seen such a bird, but that it was their traditional Takahé which they had believed to be utterly extinct. Notornis means the 
bird of the south. Mr. Gould has published a coloured figure of the probably now extinct notornis, which was unquestionably the contemporary of the gigantic dinornis. It possessed bright scarlet legs and beak; the neck and body are of a dark purple colour, the wings and back being shot with green and gold.

In the Dawn epoch this order of bird was represented by "a curlew of the size of the ibis," and by species allied to and of the size of our woodcocks, lapwings, and sanderlings.

Wading birds were numerous in the succeeding Miocene epoch, many of their remains having been discovered in the Miocene lacustrine deposits of Cantal.

Professor Owen has described a large bird (Gastornis Parisiensis) from the Eocene Tertiaries of Paris, "with affinities to the Waders and Palmipedes, or Aquatic birds."

\section{Order 8.-WEB-FOOTED BIRDS. Palmipedes.}

The large webbed feet serving for oars are the great characteristics of these birds. Some, as the Penguin (Aptenodytes) and Great Auk (Alca), cannot fly; while the Frigate-bird, so unsurpassed in its power of wing, is web-footed, yet seldom, if ever, alights on the water. The position of the legs in the Divers is farther backward than in any other birds, and their wings are employed as fins. Some of these birds are nearly as aquatic as fishes, of which they are great destroyers; and the adaptation and design manifested in their structure are very remarkable. Cuvier remarks, that these are the only birds in which the neck exceeds-and sometimes considerably - the length of the legs. Swimming on the surface, they can thus dip deeper to seize their prey. 
The Penguins are the most aquatic of all birds; their feathers are almost reduced into the condition of scales, and their wings to fins. The Albatross (Diomedea), Gulls (Lari), and Petrel (Procellaria) have long and powerful wings. The Stormy Petrel is well known as an ocean bird, which, in the length of its wings and the swiftness of its flight, equals the swallow. Mr. Darwin gives an extraordinary and interesting instance of modification of structure eren in birds so truly aërial as the petrels. He informs us, that there lives a petrel, in the quiet, undisturbed Sounds of Tierra del Fuego, with many parts of its organization so modified that it flies unwillingly; while in its astonishing power of diving it might be taken for an auk or a grebe.

The Great Auk (Alca impennis) is become so extremely rare, that it may be considered as nearly extinct. This bird appears to have been a northern short-winged Palmipede bird, as the penguin is an antarctic bird. We learn that the bones of this bird are abundant in the old refuse heaps or "kitchen middens" of Denmark.

The Little Auk (Mergulus) exists in myriads. It frequents the coast of Spitzbergen in such amazing numbers, that nearly four millions have been calculated to have been seen, at one time, on the wing.**

In the Waterfowl Inclosures of the Zoological Society is a choice collection of Palmipedes. Among these are specimens of the Upland Goose, from the Falkland Islands, where they breed in great numbers. These are birds which Mr. Darwin instances as having transitional habits; "upland geese, with webbed feet, which rarely or never go near the water." The Flamingo (Phanicopterus) is a bird of peculiar structure, and which has been ranked with the Waders; but we learn from Sir W. Jardine, that "it is a Grallatorial duck." The flamingo is in the Old Aviary; and is from the Mediterranean.

In clay of the Dawn epoch fossil remains of birds of * Jardine's "Naturalist's Library," vol. iv. p. 226. 
the seagull and heron families have been found at Sheppy and at Highgate. Birds allied to the pelican and wild duck have also been found fossil in rocks of this epoch, on the continent,* with species allied to the cormorant, and akin to the Divers.

In Pliocene deposits, the remains of the "fossil metatarsal of a swan" have been discovered, not distinguishable, says Professor Owen, from that of the existing wild swan; and in the Post-Pliocene clay of Lawford, a fossil humerus, like that of a wild goose. Terns, pelicans, ducks, and divers have been found in the PostPliocene deposits; and in New Zealand there have lately been discovered, by Mr. Walter Mantell, the son of the celebrated geologist, Dr. Mantell, the fossil relics of a penguin, in strata possibly as old as the Eocene Tertiaries.

This bird is described by Professor T. H. Huxley, $\uparrow$ as approximating to the crested penguin (Eudyptes chrysolophus); but he cannot regard it as belonging to any known genus, and therefore has called it the Palæeudyptes (ancient Eudyptes).

The bone described by Professor Huxley was found by a native in the limestone of Kakauie, which limestone is overlaid by a mass of blue clay, the blue clay being itself surmounted by a bed containing fresh-water shells; and upon this, again, lies the alluvium, in which the remains of the dinornis are found.

The marine shells contained in the blue clay and in the limestone are different from those now living in the seas of New Zealand.

"Whatever,". says Mr. Huxley, "be the precise age of the fossil, it is not a little remarkable to find, in strata of such antiquity, the remains of a bird, the whole of whose congeners are at present absolutely confined to the Southern Hemisphere; therefore, in a broad sense, to the same great distributional area. If the

* Jukes's "Manual of Geology," p. 833, and Pictet's Palæontology.

+ Proceedings of Geological Society, Feb. 1, 1S60, p. 670. 
strata be of Pliocene age, the fact is in accordance with the relations which have been observed to obtain between the recent and Pliocene fauna of the northern hemisphere. On the other hand, the little that is at present known respecting the distribution of birds in time is not inconsistent with the ascription of a far greater antiquity to a genus as closely allied as Palæeudyptes to those which now exist." 


\section{CHAPTER III.}

\section{CLASS III.-REPTILES. Reptilia.}

Reptiles possess lungs like the Mammalia and birds, but only a portion of their blood passes through their lungs. They are cold-blooded and have very little brain; many are carnivorous, and swallow their prey entire. Some are venomous, as the viper and different kinds of serpents ; others, as the crocodiles, gavials, and alligators, are large lizards (Saurians); and a few, as the turtle and tortoise, are useful for the food of man. The tortoise, lizard, and serpent have very different forms, and the skeletons of reptiles present greater variation of structure than those of warm-blooded vertebrata.

Some reptiles have the body naked, others have it covered with scales, plates, or a horny shell. Like birds, they lay eggs, which they generally abandon, and the young are hatched by the heat of the sun. The great Indian serpent python, which sometimes attains the length of forty feet, is a remarkable exception, as this monster hatches its eggs, during which period the temperature of its own body rises considerably.

Some reptiles, as the common viper of this country, are ovoviparous, that is to say, the young are hatched before being born.

As a rule reptiles, in present times, inhabit regions near the equator. They certainly diminish towards the poles.

Professor Owen has prepared an elaborate classification of reptilian animals, and has arranged them in 

thirteen orders, of which eight are extinct, and five are both fossil and still living.* The following is a summary of the Professor's classification:-

\section{Orders of Reptilice.}

Geological Epocks.

1. Ganocephala (lustrous, or shiningheaded reptiles) $\ldots . \ldots \ldots \ldots . . .$. Carboniferous.

2. Labyrinthodontia (labyrinthine-tootbed reptiles) ................. Triassic.

3. Ichthyopterygia (fish-finned reptiles) Lias to clalk.

4. Sauropterygia (lizard.finned reptiles).. Trias to chalk.

5. Anomodontia (tooth-wanting reptiles) Triassic.

6. Pterosauria (winged saurians)........ Lias to chalk.

7. Thecodontia (socket-toothed reptiles).. Triassic.

8. Dinosauri (terrible saurians) ......... Lias-greensand.

9. Crocodilia (crocodiles) ............ Lias to present time.

10. Lacertilia (lizards, monitors) ........ Oolitic to present time.

11. Ophidia (serpents, slow-worms) ...... Tertiary-living.

12. Chelonia (tortoises and turtles) ...... Trias to present time.

13. Batrachia (toads, frogs, newts) ....... Oolitic to present time.

"As to the class Reptilia," says Sir C. Lyell, "some of the orders which prevailed when the secondary rocks were formed, are confessedly much higher in their organization than any of the same class now living." +

\section{Order 1.-SHINING-HEADED REPTILES。}

\section{Ganocephata.}

The name of this order was assigned by Professor Owen, from the sculptured and externally polished, or ganoid bony plates with which the head was covered, and to this order the oldest known reptiles appertain. They were formerly referred to the class of Fishes, unti? specimens were discovered in Germany, which enabled the comparative anatomist to determine the reptilian characters. We learn from Sir C. Lyell, $\neq$ that the first

* Reports, British Association, 1859.

+ "Antiquity of Man," p. 402.

+. "Manual of Elementary Geology," 5th edit., P. 400. 
skeleton of these ancient reptiles was announced by H. Ton Meyer, in 1844, from the Carboniferous rocks of Munster Appel, in Rhenish Bavaria. The skulls, teeth, a large portion of the skeletons, and even a part of the external covering of the body, consisting of wedge-shaped scales, of two other reptiles, were preserved in the Carboniferous clay of the coalfield of Saarbrïch, and were described by Professor Goldfuss, under the name of Archegosaurus (primeval lizard), in 1847. Had any person ventured to prophesy, thirty years ago, that reptilian animals would be discovered in the Coal formation, he would have been set down as a heretic!

Some animals present us with organization so intermediate as to make it difficult to determine to which class of animals they belong.

The existing Lepidosiren, a specimen of which may be seen at the Crystal Palace at Sydenham, is an example. For some time naturalists were puzzled to determine whether this animal was a reptile, a fish, or an inter. mediate animal.

During the epoch of the Old Red Sandstone, numerous ganoid, or shining-scaled fishes, frequented the ancient seas; but it is not until the Carboniferous period, which succeeds that of the Old Red, that we meet with the primeval lizard. It is, therefore, most interesting and important to know what relation the archegosaurus bore, first to fishes, secondly to the Old Red fishes, and thirdly to the existing reptilian class. These are the points interesting to the naturalist.

The remains of the archegosaurus were referred by no less an authority than Professor Agassiz to the class of fishes (Pygopterus Lucius, Agassiz); and it is impossible to read Professor Owen's description of this old reptile without believing that the archegosaurus was created after the type of the Old Red Ganoidal fish.

The vertebral column of the archegosaurus presents an embryonal condition, and "in this structure the old Carboniferous reptile resembled the existing lepidosiren." 
"Both illustrate the artificiality of the supposed class distinction between fishes and reptiles." ${ }^{*}$ If we rightly understand Professor Owen, the ancient Ganoidal archegosaurus represents the march of development from the Ganoidal fish of the Old Red Sandstone, into the more elaborate Labyrinthodont reptiles of the Trias; as the living lepidosiren represents the march of development from the fish, through the Batrachians (frogs), to the lower existing orders of the reptile class. Myriads of ages ago, the archegosaurus was an animal intermediate betreen the fish and the reptile, possessing more of the reptilian character than the lepidosiren, which is an intermediate animal now living.

In 1852, Sir C. Lyell and Mr. Dawson obtained portions of the skeleton of a reptile from the interior of one of the great coal-plants, an erect Sigillaria, which grew on the ancient land of Nova Scotia. The shell of an air-breathing mollusk, allied to Bulimus or Pupa, had been washed into the hollow tree with the skeleton of the reptile. This is the oldest known land shell, the first air.breathing mollusk yet discovered; and is interesting as associated with the earliest of known air-breathing quadrupeds. Several of the land shells have since been detected in the Nova Scotia coal-fields. The reptile is named Dendrerpeton (Tree-lizard), and from its close affinities to the archegosaurus is ranked by Professor Owen in the Ganocephalous order.

The remains of another reptile (Raniceps) hare been discovered in a seam of coal in Ohio, United States, and have been referred, by Professor Wyman, to the Batrachians.

Footprints of much larger reptiles than those of archegosaurus or dendrerpeton bave been discovered in America by Dr. King; while, in Great Britain, footmarks of reptilian animals have been detected by Hugh Miller, Mr. Binney, and the Rev. C. Bromby, in rocks of Carboniferous age. 
These footmarks are impressed upon ancient beaches, and associated with sun-cracks and rain-drops. The study of fossil footsteps, shrinkage-cracks, rain-marks, ripple-marks, and worm-cracks, has added much to the data of geologists. The splendid work on the Ichnology (footprints on stone) of Annandale, by Sir William Jardine, is illustrative of the footprints of fossil reptiles that lived in the Permian period, which succeeded the long Carboniferous epoch, whilst the great work of Professor Hitchcock, of America, on the Ichnology of Massachusetts, should be consulted by all earnest students of geology.

\section{Order 2.}

\section{LABYRINTHINE-TOOTHED REPTILES.}

\section{Labyrinthodontia.}

Professor Oren informs us that the archegosaurus conducts the march of development from the fish proper to the Labyrinthodont type.

The Labyrinthodons were so named, from the complex structure of their teeth. These extinct and remarkable reptiles lived during the Carboniferous epoch; for one named Baphetes (a diver), so called from the position and shape of the head, was described, in January, 1854, by Professor Oren, from the coal-field of Pictou, Nova Scotia.

We learn also, from the comparative anatomist, that the Labyrinthodont reptiles manifested an affinity to fishes in the structure of their teeth; that in the rest of their structure they manifested characters of the lowest reptilian order, viz., the Batrachia; and that with the characters of the Batrachia, they combine other bony characters, of crocodiles, lizards, and the ancient Ganoid fishes.

Judging from the fossil bones and footprints, some of 
the Labyrinthodonts must have been of large size. The Labyrinthodon has been generally beliered to have been a kind of crocodilean frog, but Professor Huxley's examination of many relics of this reptile has induced him to come to the determination that it was a large salamander-like beast. The Labyrinthodon Jagaeri must have been an awful creature, if we may judge from the canine teeth, and the large hand-like impressions left on the slabs of the New Red sandstone epoch.

Impressions of the feet of a Labyrinthodon were found by the late Mr. Hugh Strickland in the lower Keuper sandstone of Shrewly common, Worcestershire; and bones and teeth have been discovered near Kenilworth, in the Permian sandstones of the Geological surveyors, as well as in the upper Keuper beds, where they have been detected by the Rev. Mr. Brodie. Five species of Labyrinthodont reptiles have been found in Great Britain, all of which must have been very unpleasant-looking animals, with fearful jaws adapted especially for biting. And yet such animals lived on the shores of a sea-bed which now constitutes much of the pleasant rales of Worcestershire and Cheshire, the shores of the New Red sandstone sea.

The remains of the Labyrinthodon have been found, during the last twelve months, by Dr. Buchanan Holl, of Malvern, and myself, in the Keuper sandstone of Worcestershire. Professor Huxley has lately described two or three new species of Labyrinthodonts from the coalfield of Edinburgh.

\section{Order 3.-FISH-FINNED REPTILES.}

\section{Ichthyopterygia.}

This order appears to retain an affinity to fishes in the structure of the fins, and several other particulars, too recondite for any but an anatomist to enter into. The Ichthyosaurus is a fish-finned reptile. Who does not 
know the Ichthyosaurus? Who has not seen his skeleton and grinning jaws, or wondered at the marvels of its stoney eye-plates? Who has not disinterred the vertebræ, or ribs, from some lias quarry?

So abundant were the different species of Ichthyosaur during the epoch of the Lias, that I hardly know a Lias quarry which has not afforded portions of the fossilized skeletons of these extinct reptiles. I have disinterred the greater part of the skeleton of an Ichthyosaur from a Lias outlier, the Berrow Hill, within two miles of the range of the Malverns; and on the same day $I$ have visited some half-dozen quarries, many miles apart, in all of which I have seen fragments of the "fish-finned" saurians. One bed of the lower Lias might appropriately be called the Saurian's grave, so charged is it with relics of these animals.

I do not here refer to the Bone bed, which is now, owing to the researches of Sir P. Grey Egerton, ranked as the uppermost Triassic deposit, but to the Ostrea and Saurian bed of the lower Lias. It lies a few feet over the insect limestone of Brodie, and contains a rast number of the relics of Ichthyosauri. The Ichtbyosaurus respired air from the atmosphere, like the whales, and not through a watery medium, like fishes. The general outline was that of a large porpoise with enormous eyes, defended by a series of overlapping plates, - a mechanism analogous to that observable in the eyes of turtles, tortoises, lizards, and birds, and which confers on the eye great power of vision as rell as being a defensive apparatus to the capsule. From the bony structure connected with the fore-fins, "Professor Owen concludes that the Ichthyosauri occasionally "sought the shores, crawled on the sand, and basked in the sunshine," and that "its general external figure must have been that of a huge predatory fish, scaleless, and covered by a smooth or finely-wrinkled skin, analogous to that of the whale tribe." The teeth of this animal were very numerous, and abound, with broken pieces of the jaw, in the lower Lias quarries. 


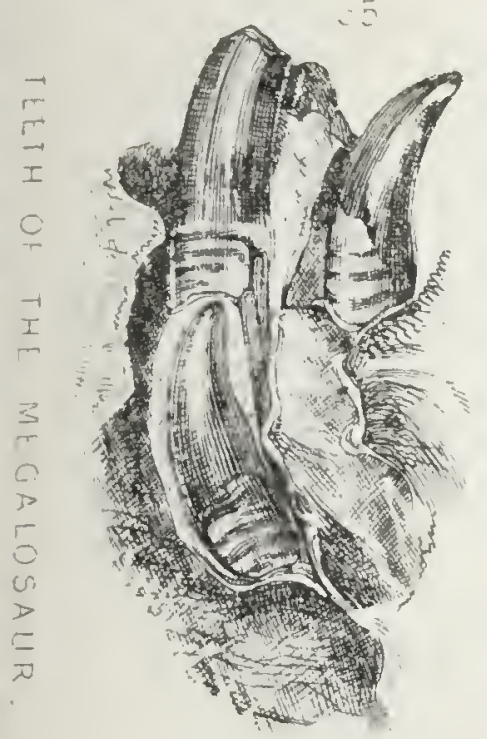

\section{6}

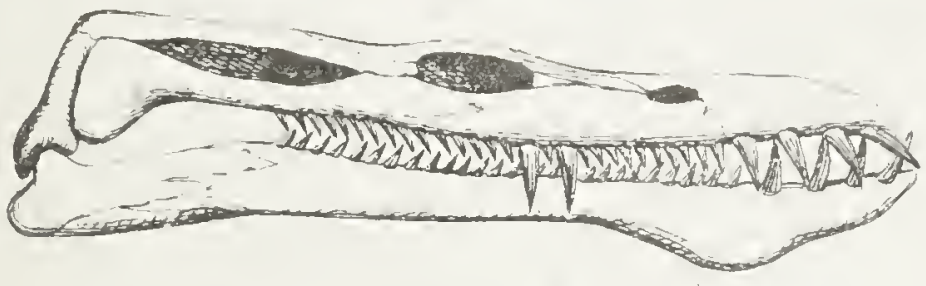

NOTHOSAURUS (TRIAS).

59
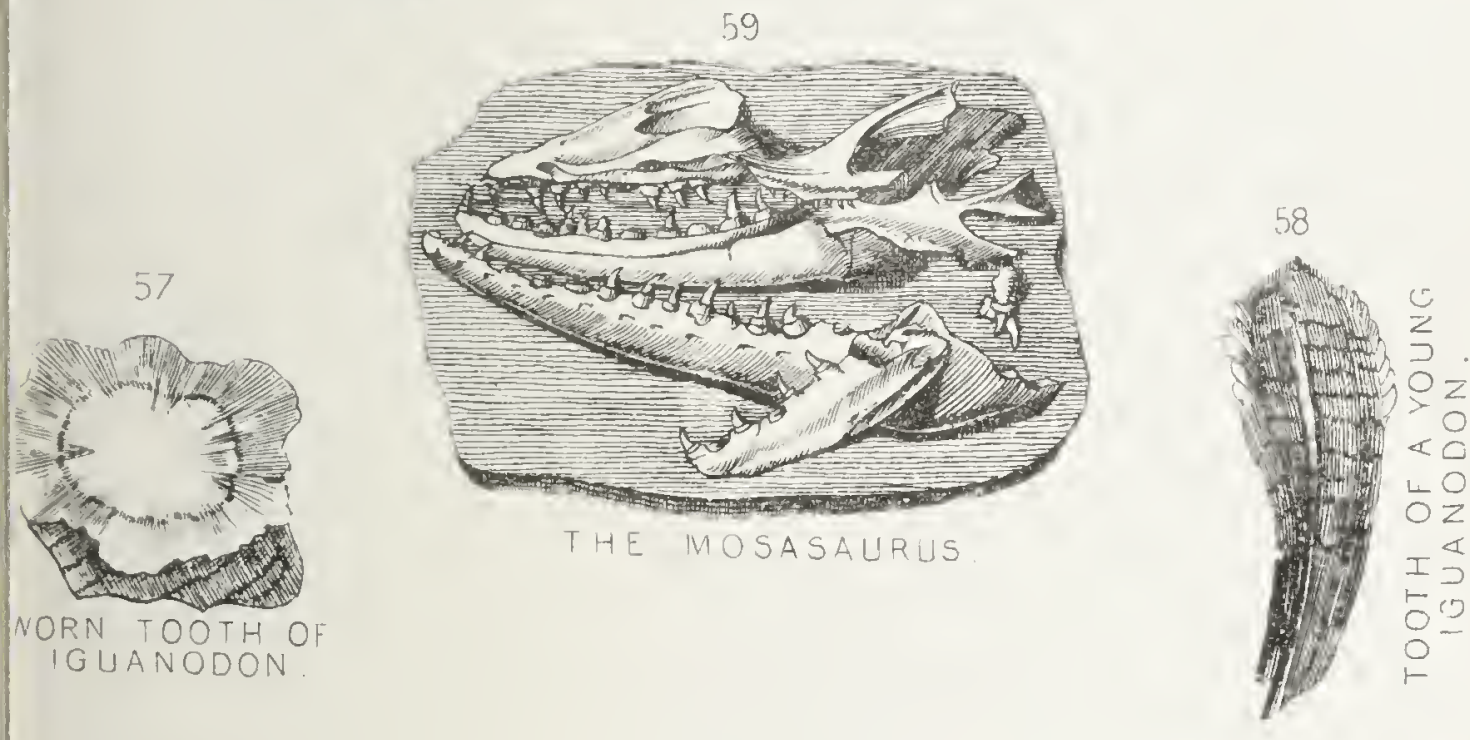

NORN TOOTHO

I GUANODON.

60
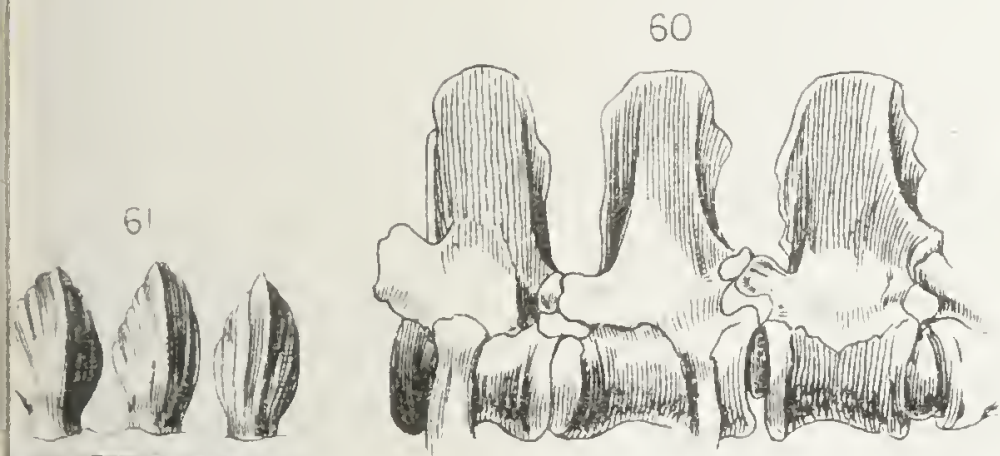

$6 !^{a}$

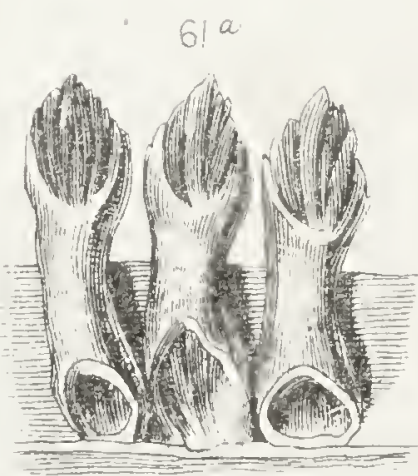

ETHOF IGUANA

CIP\& BAI: :ERTEBRE

L LERCULATA 

Portions of the integuments, in a carbonized state, may also occasionally be met with. Sir Philip Egerton discovered the phalangeal bones of a paddle at Barrow-onSoar, with the soft parts lying in their natural position. Mr. Moore, of Bath, possesses remains of the skin in a wonderful state of preserration. The remains of fish and small reptiles are occasionally found in the stomach of the Ichthyosaurus, and the coprolites not only show the nature of the animal's food, but also bear the form of the intestinal canal, which we thus know to have been spirally convoluted, as in the corresponding organs of the shark and dog-fish. A coprolite which I found at Sarnhill, near Tewkesbury, has imbedded in it the humerus of a juvenile Ichthyosaur with the scales of a Lias fish.

More than thirty species of Ichthyosaurus are known. Some of them must have been gigantic, as witnessed by the remains in the British and Bristol Museums. I have seen teeth over two inches and a half in length, in the quarries of Brockeridge Common, near Upton-on-Severn, and vertebræ that measured five inches across. The most common species was about eight or nine feet in length.

Remains of the Ichthyosaurus hare been found in the Arctic regions by Sir Edward Belcher.

The remains of a marine saurian (Eosaurus Acadianus), from the coai formation of Nova Scotia, described by Mr. Marsh ("Quarterly Journal, Geological Society," February 1863), indicate points of similarity to the Ichthyosauri, and are of high reptilian structure.

\section{Order 4.-LIZARD-FINNED REPTILES. \\ Sauropterygia.}

Some of the most remarkable of the proofs of the correlation of Palæontology with the Geologic record may be gathered by a perusal of Professor Owen's chapters on the Reptilia in his work on Palæontology.

It is very evident, from the professor's account of the G 2 
Archegosaurus, that this ancient reptile was simple in structure and altogether rudimentary. Simple and rudimentary also are all the known reptiles of the Carboniferous epoch; while, no sooner do we pass the boundaries of the Carboniferous horizon, and enter upon the Permian and Triassic periods, than we find an advance in the organization of reptiles. The Permian Protorosaurus and Rhophalodon were decidedly of a higher order than any that have hitherto been discovered in the Carboniferous deposits, and Professor Owen gives a diagram of the skeleton of the Nothosaurus of the German Muschelkalk, a deposit of the New Red sandstone epoch, for comparison with that of the Archegosaurus, and to prove the advance in the organization of aquatic reptiles.

The Plesiosaurus is ranked by $\mathrm{O}$ wen among the lizardfinned reptiles, and the name signifies "nearly allied to a lizard." The Plesiosaurus has been discovered in a beautiful state of preservation, the entire slieleton having been petrified in the soft mud, now turned to clay, in which it was entombed. The contour of the animal is so remarkable, that it has been graphically compared to a serpent threaded through the shell of a turtle.

Baron Cuvier believed the structure of the Plesiosaurus "to have been the most singular, and its character the most anomalous, that had been discovered amid the ruins of a former world." "To the head of a lizard it united the teeth of a crocodile, a neck of enormous length, resembling the body of a serpent, a trunk and tail having the proportions of an ordinary quadruped, the ribs of a chameleon, and the paddles of a whale." We learn also, that of existing reptiles, the lizard, and amongst them the old-world Monitors, most resemble the Plesiosaur in the structure of the skull. The Plesiosaurus ranges from the Trias (bone-bed) to the Chalk, inclusive, and some twenty species are known. They were marine animals, and their Muschelkalk predecessors "were better organized for occasional progression on dry land." The vertebræ are easily known from those of the 
Ichtbyosaur: they are longer and less concave. The teeth are conical, and more slender and pointed than those of the Ichtbyosaur; they are also slightly recurved.

Fine specimens of the fossil skeletons of this animal may be seen in the British, Bristol, York, and Warwick Museums. There are many other genera of lizard-finned reptiles; as the Pistosaurus, Pliosaurus, Simosaurus, and Polyptychodon.

Dr. Stead Jones, of Ely, possesses some remarkably fine teeth of some enormous saurian, probably Polyptychodon, from Kimmeridge clay near the town of Ely, as also does Mr. Bard, of Ely, to whose courtesy I am indebted for a fine tooth now in the Worcester Museum. Every geologist should, if possible, see the saurian relics at Ely. Some of the owners of those fossil teeth must have been as large as existing whales.

The Placodus (plate-toothed) is an extraordinary fishfinned reptile, found in the Muschelkalk (Trias) of Germany. The development of the teeth and jaws of this animal, as described by Owen, is indeed marvellous. "The temporal fossa are the widest, and zygomatic arches the strongest, in the whole class Reptilia; the lower jaw presents a like excessive development of the coronoid processes. These developments, for great size and power of action of the biting and grinding muscles, relate to a most extraordinary form and size of the teeth, which resemble paving-stones, and were evidently adapted to crack and bruise shells and crusts of marine invertebrata." * Some Australian lizards of the present day have rounded teeth, adapted for crushing hard substances, and have therefore received the generic term of Cyclodus (circle-toothed). 
Order 5.

\section{TOOTHLESS REPTILES, or REPTILES WITH INCONSPICUOUS TEETH.}

Anomodontia.

Several species of an extinct order of reptiles, named Dicynodon (two tusks), have been found in Africa by Mr. A. G. Bain.

These singular animals presented in the construction of their skull the characters of the crocodile, the tortoise, and the lizard; but the only teeth developed were "two sharp-pointed tusks, growing downwards, one from each side of the upper jaw, like the tusks of the Walrus (Trichecus)."

The Rhynchosaurus (beaked lizard) of the New Red sandstone belongs to this order, and to the Cryptodont family of Owen; so called from the animals which compose it being edentulous, or having inconspicuous teeth. The Rhynchosaurus has been found at Grinshill, near Shrewsbury, and I saw, some years ago, a remarkably fine specimen of the skull in the possession of a widow woman at the village of Clive. There are no teeth apparent in either jaw, and the resemblance of the mouth to the compressed beak of certain sea birds, with other peculiarities of structure, leads Professor Owen to believe that "the ancient Rhynchosaur may have had its jaws encased by a bony sheath, as in birds and turtles."

I saw the Rhynchosaurus of Grinshill under the guid. ance of Mr. T. C. Eyton, of Eyton Hall. Mr. Eyton offered a considerable sum for the fossil, but in rain, the owner declining to part with it. It is a specimen however to be noted, as regards its whereabouts, lest it should be hereafter forgotten and thrown aside. Footprints of a small reptile have been obtained by Sir William Jardine from the Grinshill sandstones, and in the same slab are broken fragments of reptilian bones. 
These are, in all probability, the footmarks of the Rhynchosaur.

Remains of fossil plants are abundant in the Ombersley sandstones of Worcestershire, and the Echinostachys oblongus, found by Mr. Hugh Strickland, was considered by Dr. Lindley to be identical with the specimens described by M. Brongniart from the "Grès bigarré." I consider these Ombersley sandstones to be the equivalents of those of Grinshill.

\section{Order 6.-WINGED LIZARDS. Pterosauria.}

This group, or order of reptiles, is altogether extinct, for not one species remains. The winged reptiles have not been found previons to the Liassic epoch, and appenr to have died out before the commencement of the Tertiary ages. The far-famed Pterodactyle is a Pterosaur. Its remains have been found by Mr. Brodie as low in the geological scale as in the lower Lias of Gloucestershire; and bones have been detected in the coeval beds of Germany. Many species have been described. It was not merely in magnitude, observes the illustrious Cuvier, that reptiles stood pre-eminent in ancient days, but they were distinguished by forms more varied and extraordinary than any that are now known to exist on the face of the earth. "Its power of flight must have far exceeded that of the Draco volans, the only existing reptile that can traverse the air, and probably equalled those of the bat."* It had a long-snouted head, and long neck, with jaws armed with sharp and pointed teeth. The eye was very large; and we learn from $O$ wen that "the weak pelris and hind limbs bespeak a creature unable to stand and walk like a bird; and that the body must have been dragged along the ground like a bat."

* "Oss. Foss.," t. v, p. 35s. "Ce n'étoit pas seulement," \&r. 
The body was not covered with feathers, but probably with a thick skin, and the "whole osseous system is modified in accordance with the possession of wings; the bones being light, hollow, most of them permeated with air-cells, with their compact outer walls."

The Pterodactyles are distributed into sub-genera, according to well-marked modifications of the jaws and teeth. The teeth of one genus are of two kinds, and it is therefore named by Owen Dimorphodon (teeth of two forms): it is the oldest known species from the Lias.

The Dimorphodon macronyx was, when living, about the size of a raven; and the skeleton was discovered by the late Mary Anning in the lower Lias of the coast of Dorsetshire, near Lyme Regis. This specimen is now in the British Museum, and was described by Dr. Buckland. Dr. Bowerbank first recognized the difference, by microscopic investigation, between the form and proportion of the bone-cells in birds and the flying reptiles. He has a fine collection of Pterosaurian fossils; some specimens from the Kentish chalk, indicating a width of wing of from sixteen to eighteen feet. Bones of Pterosaurians are abundant at Sarsden, near Chipping Norton, in Oxfordshire, associated with remains of Megalosaurus and of Oolitic fishes. The beds are the equivalents of the Stonesfield slate, and Professor Huxley has determined that the Pterosaurian relics of the Stonesfield slate belong principally to the genus of flying reptiles denominated Rhamphorhynchus, from the fact of the anterior end of the jaw passing into an edentulous point, to which a horny beak was probably fitted.

Dr. Wright, of Cheltenham, my friend Captain Guise, and the Rev. Mr. Witt, have collected Pterosaurian bones and teeth from the Stonesfield slates of Gloucestershire, all of which belong to the genus Rhamphorhynchus. Professor Huxley informs us that "seven feet may be safely assumed as the minimum distance between the extremities of the two wings" of the largest Rhamphorhynchus, which he has described from a specimen in the possession of Earl Ducie. 
There are two very useful diagrams, 'prepared by Mr. S. J. Mackie, given in the January number (1863) of "The Geologist," which afford an idea of the distribution in time of the various orders of birds and flying reptiles.

\section{Order 7.-SOCKET-TOOTHED SAURIANS.}

\section{Thecodontia.}

The remains of the reptilian fossils called Thecodonts, from having their teeth implanted in distinct sockets, as in the crocodile, were first discovered by Dr. Riley and Mr. Stutchbury in the Dolomitic conglomerate of Redland, near Bristol.

The Palæosaurus (ancient lizard) has been found at Redland; and a nearly-allied genus, Cladyodon, was founded by Professor Orren on some reptilian relics described by Murchison and Strickland from the Red sandstones of Warwickshire, now understood to be of Permian age.

The remains of the Telerpeton (a far-off reptile), or Leptoplenron lacertinum of Owen, a small lizard-like reptile, were discovered in the Elgin district, in a rock intermediate between the upper Old Red sandstone as the base, and a series of Triassic and Lower Liassic strata above. With the Telerpeton have been found other reptilian remains, showing affinities to lizards and crocodiles, one of which is the Stagonolepis, or pitted scale, and another the Hyperodapedon Gordoni.* All the reptiles, in fact, which have been found in the reptiliferous sandstones of Elgin are considered by Professors Owen and Huxley to have general affinities with the Mesozoic reptiles.

Mr. Moore, of Bath, when visiting the section at Linksfield, near Elgin, in the autumn of 1859, recogmized a similarity of appearance between the shales and

* Quarterly Journal, Geological Society, Aug. 1, 1859, p. 440. 
thin limestone bands at Linksfield and those of the Bonebed series (at the summit of the Trias), at Pyll Hill, near Bristol; at Aust Passage, at Penarth, on the Severn; and at the Uphill cutting, on the Great Western Railway. Mr. Moore also collected remains of Plesiosaurus, Hybodus, Lepidotus, Acrodus, with Cypris, the Keuper Estheria (the Estheria minuta of Mr. T. Rupert Jones), and Mytilus, Modiola, Unio and Cyclas, from the Linksfield beds. Having been informed by Mr. Moore of his belief that the Linksfield beds were Lower Liassic and Triassic, and having seen the fossils he had collected, I visited the Elgin district, in company with the Earl of Enniskillen, Sir C. Lyell, Sir W. Jardine, and Professor Harkness, for the study of the physical relations of the Elgin rocks.

Without entering into the details necessary to describe the physical geology of this difficult district, I may mention that I entirely agree with Mr. Moore in his correlation of the Linksfield strata, and that they belong to the age of the Upper Trias and Lower Lias.* The Rev. Mr. Joas, of Edderton, has discovered the equivalents of the reptiliferous strata of Elgin at Portmahomack, on the N.T. coast of the Moray Frith.

\section{Order 8.-TERRIBIE SAURIANS. Dinosauria.}

The teeth and bones of a large carnivorous reptile named the Megalosaurus (great lizard) have been found in the lower Oolite rocks of Gloucestershire, at Selsby Hill and Chipping Norton. They are abundant in the Stonesfield slate, and in the Wealden and Purbeck deposits. Specimens of teeth and bones are preserved in the British Museum, and in the Museums at Oxford and Cirencester, also at Bristol. The first scientific determination of the nature and relations of this reptile

* See Edinburgh New Philosophical Journal, July, 1860. 
was by Dr. Buckland in 1824. The character of the teeth leaves no doubt that the Megalosaur was a carnivorous reptile; it appears also to have been terrestrial, and probably preyed on smaller reptiles, and on the young of its contemporaries, the gigantic Iguanodon and Hylæosaur. The structure of the teeth, and their adaptation for destruction, are admirably described by the late Dr. Buckland.*

The Hylrosaurus, or lizard of the forest, was another gigantic terrestrial reptile, first discovered by Dr. Mantell in the Wealden strata. It probably attained a length of twenty-five feet; while the Megalosaur is supposed to have reached thirty feet in length. We are informed by Owen that the teeth indicate "a mixed or regetable diet, rather than a carnivorous one."

The Iguanodon was an immense herbivorous Dinosaur, the relics of which are found in the Weald of Sussex. It is named from the resemblance of its teeth to those of the existing Iguana of South America. Dr. Mantell and Baron Cuvier were the first to detect the deriation, in this gigantic reptile, from all the known types of reptilian organization; and their discovery has been followed up by Professor Owen. $\dagger$ "The Iguanodon was distinguished by teeth resembling in shape those of the Iguana, but in structure differing from the teeth of that and every other known reptile, and unequivocally indicating the former existence, in the Dinosaurian order, of a gigantic representative of the small group of living lizards which subsist on regetable substances." The Iguanodon must have been a colossal herbivorous reptile, adapted, like the large herbivorous mammalia of our own and former geological periods, to obtain support from regetable substances. Dr. Mantell thought it probable that the largest Iguamodons may have attained a length " of from sixty to seventy feet." The remains of cycadeous plants are found embedded with its relics, and 
may have constituted its food. A good restoration, by Mr. Hawkins, may be seen, with other representations of extinct animals, at Sydenham.

Professor Buckman has found the fossil eggs of some reptile in the Inferior Oolite of the neighbourhood of Cirencester. The footprints of the Iguanodon, and probably of one or two other Dinosaurs, have also been discovered in the Wealden beds of the Isle of Wight, Swanage, and of Hastings. They have been described by Mr. A. Taylor and Mr. Beckles in the Journal of the Geological Society.*

\section{Order 9.-CROCODILES. Crocodilia.}

Living Crocodiles are divisible into three genera. The true Crocodiles are found in Africa, and may be known by their broad heads. The Gavials inhabit Asia, and have long pointed heads; and the Alligator frequents tropical America, and is flat-headed. All these genera differ in the arrangement of their teeth.

There are many extinct genera of these reptiles; and Professor Owen has divided the order into three distinct groups, determined by the shape of the rertebræ and the modification of the teeth. He named the genus Cetiosaurus, from a resemblance to the whale and its gigantic proportions; some of the vertebræ of the tail of a cetiosaurus, from the Portland Oolite, measure seven inches nine lines across, and seven inches in length.

All the existing forms of crocodiles are procolianthat is to say, the vertebræ have the cup at the forepart, and the ball behind; whereas we learn that the similar but more ancient forms from the Lias and Oolite had the vertebral surfaces hollowed at both ends. The number of teeth is greater in the Gavial of Asia, than in

* Quarterly Journal, Geological Society, Aug. and Nor. 1862. 
either the Crocodile of Africa or the Alligator of America. The first appearance of Crocodilians with rertebræ, like those of living species, is in the Green-sand of North America. Forms of these animals, allied both to the gavial and the alligator, were associated with true crocodiles in the tertiary rivers of ancient England.

There is in the British Museum the sliull of an Asiatic crocodile, which must have been between thirty and forty feet in length. Mr. St. John informs us that in Borneo these monsters have been known to strike men from the prow of a canoe with a blow of their tail. It also appears from his account that the gavial lays her eggs in the jungle, some distance from the water's edge.

\section{Order 10.-LIZARDS, MONITORS, IGUAIJ}

\section{Lacertilia.}

Many persons suppose that the common Newt (Triton) is a lizard, and it is generally so called. Nevertheless, the newt is not a lizard, but belongs to the frog and salamander tribe, the Batrachia or Amphibia.

Specimens of true lizards may be studied in the Gardens of the Zoological Society in the Reptile House; and among the most remarkable forms, are the Stumpedtailed Lizard (Trachydosaurus rugosus), the Great Cyclodus (Cyclodus gigas), the Sand Lizard (Scincus marinus). The Monitors frequent the haunts of crocodiles, and are so called from a marning, whistling sound, which they are said to give on the approach of those dangerous reptiles. The Iguanæ are common in tropical America, where they live on trees, and subsist on fruit, grain, \&c. The female deposits eggs as large as those of a pigeon.

The Cheirotes and Chalcides are forms of lizards, which appear to constitute a link between lizards and serpents.

Among the strange birds of the Galapagos Islands, 
there lives on the coasts a still stranger lizard, first made known to science by Mr. Darwin. There are two species, resembling each other in general form, one being terrestrial and the other aquatic. On the island of Albemarle they grow to the largest size, and some are four feet long and weigh twenty pounds. "It is a hideous-looking creature," says Mr. Darwin, "and when in the water swims with perfect ease and quickness." Captain Collnett in his royage, says, "They go to sea in herds a-fishing, and sun themselves on the rocks, and may be called alligators in miniature." They do not, however, live on fish. 'This is the only existing lizard that frequents the sea.

The remains of many land lizards have been found in tertiary deposits; others have been discovered in the Purbeck beds, and the remains of an enormous marine lizard, called Mosasaurus, or Lizard of the Meuse, are preserved in the Jardin des Plantes, in Paris. The Mosasaurus Hoffmani was discovered on blasting the rock in one of the caverns of St. Peter's Mountain, near Maestricht; the jaws being attached to the roof of the cavern. So precious was the relic, that when the town was bombarded during the French Revolution, the artillery was not allowed to play on that part of the city in which the fossil was known to be preserved. The head of this animal was five feet in length. Two other species are determined, one from the cretaceous beds of North America, and the other from the chalk of Sussex.

\section{Order 11.}

SLOW-WORMS, SNAKES, SERPINTS. Ophidia.

The common Slow-worm, or Blind-worm of Great Britain, the Clothonia (Clothonic Johnii), and the Glass Snake (Pseudopus), appear to be intermediate between 
the lizards and the snakes. The jaws of these animals are not capable of distention, and we learn from Cuvier that they are closely allied to the Scinques and the Seps, lizards remarkable for the shortness of their feet. The connection between the lizards and this first family of Ophidians must be very close. The true lizards have four limbs; but the lizard-serpent, the Cheirote, has two fore feet and no hind ones; and the Bipes possesses two hind feet but no fore ones; while of the blind-worm and glass-snake we are informed that they have an imperfect pelvis, a small sternum, scapulars, and also clavicles, hidden beneath the skin. Specimens of the glass-snake, clothonia, and trogonoph, may be seen in the gardens of the Zoological Society, and are classed by naturalists among the lizards, but having externally the general appearance of snakes.

The serpents may be divided into three groups-the Pythons and Boas, which destroy their prey by compression, and are gifted with wonderful muscular power; the renomous serpents, as the Rattlesnake, Cobra, and the common Viper (Pelias Beras); and the Colubrine, or harmless snakes, as the common Ring-necked Snake (Natrix torquata) of Great Britain.

The jaws of all the serpents of these different groups are adapted for swallowing animals, and therefore are capable of great distention.

The Reptile House in the Gardens of the Zoological Society contains a fine exhibition of the serpent tribe.

Some of the venomous snakes assimilate very closely in colour with their peculiar haunts, whether those are rocks, sands, or foliage, and the harmless Green-tree Snake is of grass green.

The Palrophis (ancient serpent) is the earliest known ophidian reptile, and was obtained from the Eocene tertiaries of Sheppy. We also learn from Professor Owen, that the remains of a "boa-constrictor-like snake, of about trenty feet in length, have been obtained from the Eocene tertiaries of Bracklesham; that a species of true viper has been discorered in the Miocene 
deposits of France; and three fossil snakes, allied to our common ringed snake, are known in the Caningen slates (a lacustrine deposit of the upper tertiary age), and have been named Coluber arenatus, Coluber Kargii, and Coluber Owenii.

\section{Order 12.-TORTOISES AND TURTLES. Chelonia.}

The Chelonians exhibit a remarkable modification in the skeleton of vertebrated animals. The bones of the back form a strongly-arched buckler called the carapace, and the bones of the chest present an extraordinary development named the plastron, which, with the carapace, form a shield composed of a great number of bony plates, into which the animal may withdraw itself.

The edible or Green Turtle attains a length of six or seven feet, and a weight of eight hundred pounds. It feeds upon algæ in the depths of the sea, and deposits its eggs, which are delicious food, upon the sand of the sea-shore. The Hawk-billed Turtle, which is found in the Mediterranean, feeds on shell-fish, and the flesh is not eatable.

Tortoises require very little nourishment, and can pass many months without eating; their jaws are invested with horn like those of birds. The land tortoise (Testudo) inhabits Greece, Italy, and Sardinia. It is eaten in Greece. Among the foreign species, there are several of large size. The emydes, or fresh-water tortoises, live on insects and small fish. The soft turtles (Trionyx), of the Nile, and the American rivers of Carolina, Georgia, and Florida, devour the young crocodiles and alligators as soon as they are hatched.

A tortoise (Testudo nigra) of the Galapagos grows to such an immense size that, according to Mr. Darwin, one of them required six or eight men to lift it from the 
ground. During the breeding season the male utters a hoarse roar or bellowing, and is distinguished from the female by his greater length of tail. Several of the islands of the Galapagos Archipelago have their own species of the tortoise, mocking thrush, finches, and numerous plants.

Turtles were inhabitants of this planet long before the days of aldermen and soup. Fossil footprints of Chelonian animals are described by Sir William Jardine from the Permian sandstones of Dumfriesshire; $;$ and footprints similar to these bave been discovered by $\mathrm{Mr}$. Binney in the Carboniferous sandstones.

Professor Owen has described a fossil turtle (Chelone planiceps) from the Portland stone (Upper Oolite). Mr. Mackie describes turtle remains from the Stonesfield slate in "The Geologist," for 1863; and marine turtles have been found in the Chalk, Eocene, and Miocene deposits. The estuarine, crocodile-devouring genus, Trionyx, "is represented by many beautiful species in the Upper Eocene at Hordwell." "Remains of land tortoises (Testudo), indicate several extinct species in the Miocene and Pliocene formations of continental Europe," † and Dr. Falconer discovered in India a carapace of a tortoise twenty feet in length.

\section{Order 13.-TOADS, FROGS, NEWTS. Batrachia.}

The Batrachia (Frogs, Toads, Salamanders, \&c.) were long classed with the Reptilia, but Professor Owen has determined that they approximate to the Fishes. The comparative anatomy of these animals is an intricate and elaborate problem, and far beyond our province to ex-

* Sir W. Jardine's "Ichnology of Annandale."

+ Owen's "Palrentology," p. 283. 
plain. It must suffice to say that the Batrachia belong to fish rather than to reptiles in their development, whilst in the egg,-in their fish organization, as tadpoles, at their birth; and in their circulatory apparatus after their metamorphosis. When tadpoles, they live in the water and possess gills (branchiæ), projecting externally, which disappear in most of the batrachians after they have undergone their metamorphosis. Those Batrachia which lose their external gills when adult, acquire very feeble lungs, and thus appear to be linked with the reptiles; but there are adult batrachians which never lose their gills, as the proteus and siren; and the swimming-bladder of fishes is a rudimentary lung. The circulatory apparatus also undergoes great change, after metamorphosis; but, as I understand, it is of fish rather than of reptilian development.

When the tadpole of the frog is metamorphosed into a frog, the hind feet appear first, and at some length of time before the fore feet. In the tadpoles of the salamander, the fore feet appear first, and the hind feet last; while the tail continues to grow instead of dropping off, as in the frog tadpole. The salamander is generally spoken of and considered as a lizard, for it possesses four limbs and a long tail; nevertheless, from other parts of its organization this animal is ranked with the Urodeles or tailed batrachians.

The Axoloth, a Mexican batrachian, is one of those extraordinary animals which puzzle comparative anatomists. It resembles most nearly the tadpole of a salamander, - a salamander stopped short, as it were, in its development. It is, however, a fully-developed animal, and not a tadpole.

The Siren has tufted gills, wich the shape of an eel, and no hind feet; while the Proteus is a blind batrachian, that lives in etermal darkness in the subterranean caves of Carniola, and possesses four legs almost as useless as are its rudimentary eyes.

The Lepidosiren, which may be seen at the Crystal Palace at Sydenham, possesses an organization which 

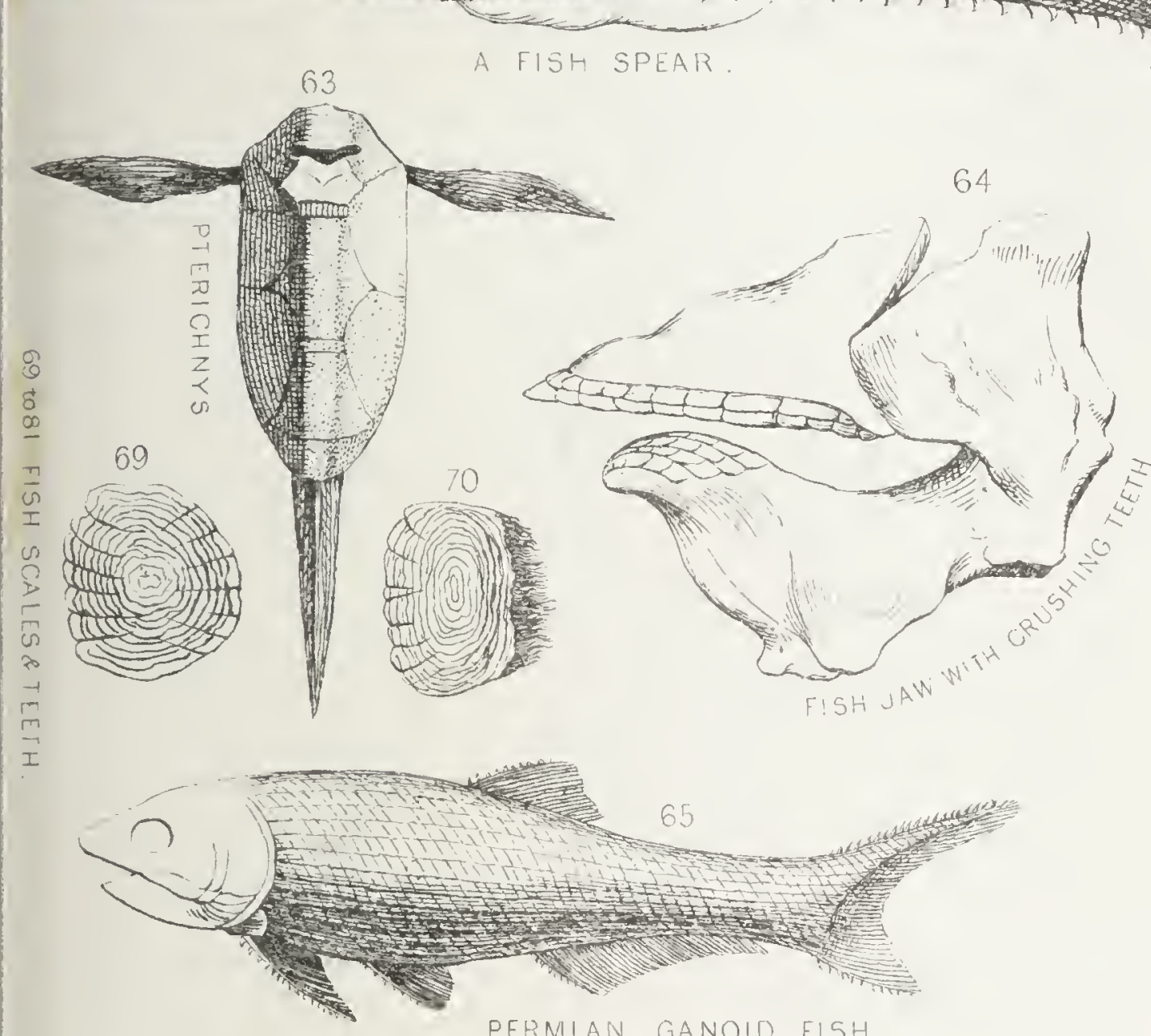

PERMIAN GANOID FISH

56

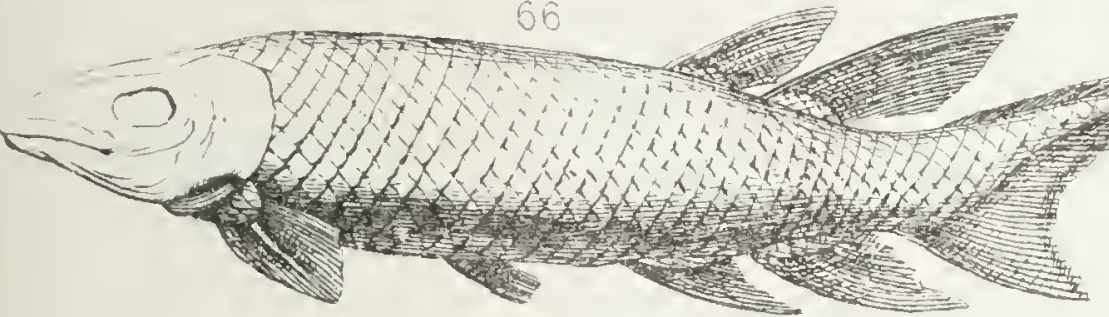

GANOID FISH OF THE OLD RED
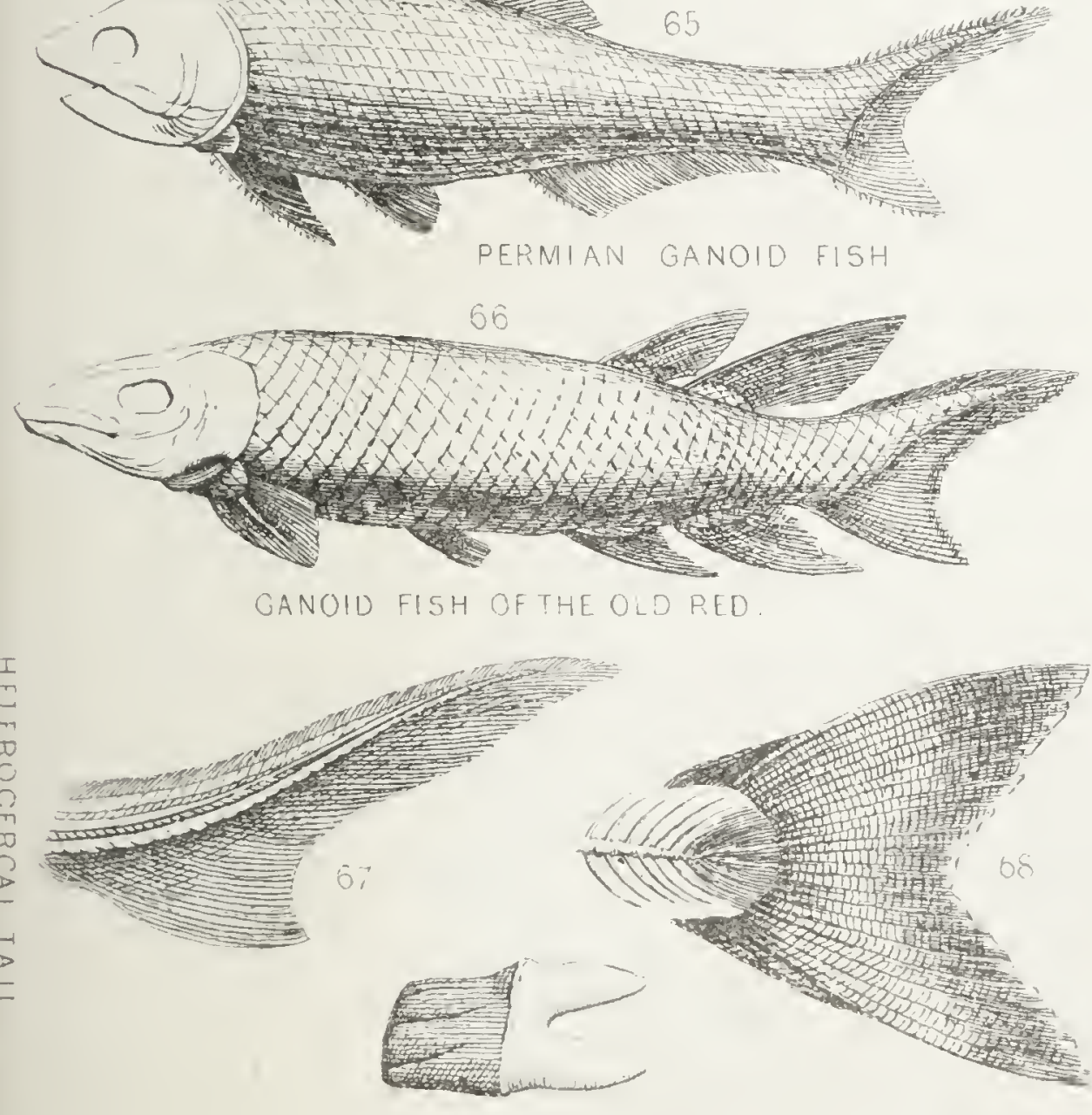

may be termed intermediate between the batrachians and fishes. It has rounded fins instead of feet, and the internal organization of a fish, but with external gills (branchiæ), and lungs like the siren. It is a fresh-water animal.

The batrachians are divided into two groups-the Anures, without tails, and Urodeles, with tails. The frog is an example of the first, and the common water-newt of the latter.

The Zoological Society of London possesses a specimen of the largest existing Amphibian, the Gigantic Salamander (Sieboldia maxima). It is a native of the Japanese island Niphon, inhabiting the lakes and streams of the volcanic range of mountains of the interior. The society also exhibits specimens of the Spotted Salamander ( $S$. maculosa), the Black Salamander ( $S$. nigra), the British Newts or Tritons (T. cristatus and T. punctatus), and the Amphiuma (Amphiuma tridactylum). These specimens are in the Python-house.

The largest known species of tailless batrachian is the Surinam Toad. The male of this species places the eggs of the female upon her back, the skin of which swells so as to form a number of cells, which inclose the eggs. The tadpoles pass their first state in these cells, until they have developed their limbs and parted with their tails. Two species of toads are found in Great Britain. The "Natterjack" is common in the neighbourhood of the Reeks, near Killarney, in Ireland. It has a yellow stripe, and has been found in Worcestershire and other parts of Great Britain. Specimens of the beautiful Tree Frog (Hyla viridis), the Green Toad (Bufo viridis), the North American Croaker, the Bull Frog (Rana mugiens), may be seen in the Python-house of the Zoological Society.

The celebrated fossil man, which was supposed to be a proof of the universality of the Noachian deluge, and the skeleton of which was discovered in the tertiary beds of Eningen, $\Delta . D .1726$, turned out to be a water salaHI 2 
mander, and is allied to the gigantic water salamander of Japan, already alluded to.

Toads of extinct species have been discovered in the same beds as the Eningen salamander; and frogs in the Miocene and Pliocene deposits of France and Germany; even tadpoles have been found fossil near Bonn.

For a retrospect of the palæontology of the great class of Reptiles we must refer our readers to the able résumé of Professor Owen.* The Professor informs us that this ancient class of animals, ancient as, at least, the far-off Carboniferous epoch, is, "unlike that of fishes, now on the wane;" and that the period when Reptilia flourished under the greatest diversity of forms, with the highest grade of structure, and of the most colossal size, is the Mesozoic, 一that long epoch, during which the middle-life forms, the myriads of animals of the Triassic, Liassic, Oolitic, and Cretaceous systems, were created, lived their appointed span, and died out.

"Reptiles have been superseded by air-breathers of higher types, which cannot be directly derived from the class of fishes."

The oldest known reptiles, which almost appear as if they were developed from the Ganoid fishes-the Ganocephalous reptiles-began and ended, as far as we know, in the Carboniferous period. The Labyrinthodonts of the Trias disappeared at the base of the Oolitic system. The Dinosaurs, Cetiosaurs, Protosaurs, and Ichthyosaurs passed away before the commencement of the Tertiary epochs. The Chelonia are on the wane, as are the Crocodiles; while the true Batrachia began to decline after the Upper Tertiary period.

* “Palæontology," p. 289. 


\section{CHAPTER IV.}

\section{Class IV.-FIS H T S. Pisces.**}

Fismes are separated into two great divisions, viz. Osseous fishes, or such as possess a hard bony skeleton, and Cartilaginous fishes, or those whose skeletons are composed of soft, elastic animal matter, termed cartilage.

In Osseous fishes the structure of the head is very complex, being composed of a great number of distinct bones; the skull of the cartilaginous fish, on the contrary, consists of a single piece, without any joints.

M. Agassiz arranges fishes into four orders, according to the structure of their scales. These are again divided into sub-orders, \&c., by Professor Owen and others.

Order 1. Broad Plated Scales (Placoids)—sharks and rays.

2. Chimeroid Fishes-king of the herrings.

3. Shining Scales (Ganoids) - sturgeon, lepidosteus, and a great number of fossil fish; as the cephalaspis, osteolepis, \&c.

"4. Comb-Shaped Scales (Ctenoids) - perch, basse, serranus, \&c.

5. Simple Marginated Scales (Cycloids) - salmon, whiting, cod, herring, \&c.

The Ctenoids and Cycloids constitute the orders comprehending the ordinary fishes with bony skeletons. The Cartilaginous fishes seem to be an approach toward the batrachian; and, on the other hand, there is an animal admitted by naturalists into the class of fishes, but placed at the bottom of the scale, which has neither vertebræ, red blood, heart, nor distinct brain. This is the Amphioxus, a rare fish, which Pallas believed to be a molluscous

* See "Palæontology" (Professor Owen's) and "Poissons Fos. siles” (M. Agassiz). 
animal, but which is now ranked as a fish of the lowest grade; and appears to be a link between the rertebrate and invertebrate animals. The Amphioxas is a British fish, and an inhabitant of the sea; it has been taken and described by Mr. Couch.

Fishes are distinguished from other vertebrated animals by their mode of respiration, being furnished with gills instead of lungs. They have to respire water, in which the oxygen is dissolved, instead of air, and their gills are beautifully adapted for this purpose.

"There are families of fishes," says Professor Huxley, in his Lectures to Working Men, "whose type of construction has persisted all the way from the carboniferous rock up to the cretaceous; and others which have lasted through almost the whole range of the secondary rocks, and from the Lias to the older Tertiaries. It is something stupendous this-to consider a genus lasting without essential modifications through all this enormous lapse of time, while almost everything else was changed and modified."

No animals exhibit such extraordinary aberration of form, or assume such peculiar shapes. Nor is this aberration peculiar to recent fishes. The semiophorus of the Tertiary deposits of Monte Bolca was as strange in contour as the Hippocampus, or the File-fish. The adaptations of fish are also astonishing. There are flyingfish; walking and climbing fish ; electrical fish ; fish with an apparatus for adhesion, as the Remora; fish adapted to tepid waters, and others to dark caves; musical fish; and fish which can live for months baked into the earth.*

I have more than once been asked by persons who have read this little work, and who have little opportunity of visiting public libraries, where they may see engrarings of the rarer forms of British and foreign fishes. I may take this opportunity of recommending the "British Fishes" of Mr. Couch, as well as that useful popular work by the Rev. J. G. Wood, already alluded 
to,* and which gives illustrations of such extraordinary forms as the Oreosoma, the Red-fire-fish (Pterois), the flying-fishes, sucking-fishes, walking-fish, climbing-perch, bellows-fish, glass-eels, the blind-fish of the Kentucky caves (the analogue of the blind reptile the proteus), the balloon and sun-fishes, the bony pike or lepidusteus, and the hag-fish, and amphioxus.

\section{Order 1.-FISE WITH PLATED SCALES. \\ Placoids.}

Sub-order.-Fishes with mouths opening under the head, or oblique-mouthed.-Sharls, rays, cestracionts. Plagiostomi.

This order is divided into sub-orders - the Plagiostomi, of which several families of the Sharks and Kays are living in the present seas; and the Cestracionts, of which most of the genera are extinct.

Fish have two forms of tails, which furnish a marked distinction. The shark and the sturgeon have their tails unequally lobed, or heterocercal (heteros, different; and cercos, a tail), and the back-bone is prolonged into the upper lobe. It is remarkable that in most of the fish found in rocks older than the Lias, their tails are unequally lobed. In the rocks above the Lias, fish affect the homocercal form of tail, that is, their tails are equally lobed (homos, alike); while in the Tertiary deposits, and at the present time, the majority of fish have homocercal tails.

The shark, dog-fish, and sturgeon affect the old type, and are examples of living fish with heterocercal tails.

The shark possesses an oblong body, lessening towards the tail; the back is broad, and supports a lofty fin; the

* Routledge's "Illustrated Natural History." 
tail is a rudder of great strength; and the pectoral fins form a pair of powerful oars. Underneath the upper part of the head are the gulf-like jaws, full of serrated, sharp teeth.

Sharks are said to hunt in company, like wolves; but no wolf equals some of these sea monsters in voracity and audacity. Gilius and Rondeletius record that a man in armour was found in the interior of a shark taken near Nice; and that another shark, when placed upon a car, was almost too heavy for a pair of horses to drag along. Sharks appear to be endowed with some of the emotions of higher animals; for Admiral Smyth mentions that he saw a large female hooked in Mahé Bay, while she was cruising around the Cornwallis, and that while she was being drawn alongside, they saw a number of young sharks rush for safety into their mother's mouth. When the belly of the shark was opened, no fewer than thirty-eight young sharks tumbled out alive; they were nearly two f'eet in length, and the mouths admitted a man's hand.*

The Dog-fishes-a genus of shark-like fishes-of the British coast are known to the frequenters of the seaside.

The Picked Dog-fish has a strong, sharp spine in front of its dorsal fins, which is generally remembered by those who attempt to handle it. Mr. Couch says that it bends its body like a bow and lashes out, directing its blows with wonderful accuracy.

The geologist learns from the ichthyologist and comparative anatomist that the small spines from the Upper Ludlow bone-beds belonged to a fish which was allied to the Dog-fish (Acanthias). The shagreen, or skin, of other small prototypes of the great Shark order of fishes has also been detected and referred to a genus named Sphagodus. These fish, although they may be ranked with the highly-developed sharks and dog-fishes, were nevertheless very small. We must not forget, also, that 
Professor Owen says that the defensive spine of the Onchus "indicates its danger ;" and that fishes of larger size, and of carnivorous habits, frequented the seas of the Upper Silurian epoch. Many fossil spines of sharklike fish have been discovered in strata of the age of the Old Red sandstone; and many species of ancient fishes have been erected on the relative shapes and sizes, \&c., of these spines. Onchus is represented in the Old Red sandstone; and I have seen some good-sized defences, belonging to fish of this genus, from the Lower Old Red of Ledbury, Herefordshire. Other fin-spines have been termed Ctenacanthus, Ptycacanthus, Pleuracanthus, \&c. This latter ichthyodorulite (spear of a fish in stone) is believed by M. Agassiz to be the spear of a fish allied to the Sting Ray (Trygon), which has on the tail a strong spine notched on both sides. The spines of the genera of fishes above named are common to the Old Red, and the succeeding Carboniferous epoch; and numerous other genera have been erected upon fossil spines found in the coal formations. The superimposed formations, the Permian, Trias, Lias, Oolitic, and Chalk formations, all furnish their fish spears, testifying the existence of shark-like owners in the seas of the different epochs.

Several species of Rays (Raia) or Skates are found in the seas of Great Britain. These fish usually lie in wait for their prey at the bottom of the sea, and their eyes are fixed on the same plane on the upper side of the head. The Torpedo ( $R$. Torpedo) is a ray that possesses the power of giving an electric shock so powerful, that when Réaumur put a torpedo and a duck into a ressel filled with sea-water, the duck was killed in less than three hours. The common torpedo is occasionally taken on the Channel coast of England.

The teeth of sharks and rays have been found in abundance in Tertiary deposits. Fossil teeth of an enormous shark (Carcharodon) have been found in the red crag of Suffolk, and indicate a fish sixty feet in length; for some of the teeth measure six inches in height. Fossil teeth of the Ray family, with their pave- 
ment-like jaws, are found in Secondary and Tertiary formations. In short, we know that fishes of the Shark and Ray order lived from Upper Silurian days until now.

The Cestracion, or "Port Jackson Shark," is one of those remarkable forms, still living, which connect the present world of living beings with forms and shapes that have long since passed away. The Cestracionts, now restricted to the seas of China and Australia, have left their remains in thousands, in rocks of the Secondary epoch in Great Britain and Europe. The Port Jackson shark, and one or two other species, are the representatives of a vast number of forms that have become extinct. The teeth of these fishes are adapted for crushing shell-fish and crustaceans, and they are provided with spines on the back for their protection. The crushing teeth, which were set as in a pavement, and dorsal spines, are full of interest to the geologist.

The Orodus of the Carboniferous rocks is the tooth of a fish, allied to the Port Jackson shark, which lived in the days of the Mountain limestone. Hybodus, a form of tooth which occurs in the Keuper sandstone of Worcestershire; and Lophodus, which is still more abundant in the same rocks, were both the crushing teeth of Triassic cestracionts. The "Fossil Leech" (Acrodus) of the Lias, and the Ptychodus of the Chalk, are teeth that belonged to fishes allied to the Australian Cestracion. Mr. Moore, of Bath, extracted 45,000 teeth of Lophodus from three cubic yards of Triassic earth. The Lophodus teeth are generally known as the Acrodus of the Trias. Sir P. Egerton and M. Agassiz consider that these teeth differ from Acrodus. They are associated with the Estheria minuta of Mr. T. Rupert Jones. 


\section{Order 2.-CHIM FROID FISHES. Holocephali.}

There is a fish known as the "Cat of the Mediterranean," and the "King of the Herrings" of the northern seas, and which closely resembles the shark in form. It is about three feet long. This is the Chimara monstrosa of naturalists. This species has occasionally been taken on our coasts, and its form is striking and peculiar, the tail tapering away until it looks like the lash of a whip. The fins also are to be remarked with their bony appendages. There is another genus or sub-genus, represented by two species from the Australian and Chinese seas, and which have the snout ending in a fleshy appendage. These are all that are now known to be living of an order of Cartilaginous fishes which, like the Cestracionts, says Professor Owen, seem "to be verging towards extinction." The genera Ischiodus, Ganodus, Edaphodus, and Elasmodus, of Egerton, were all allies, in former geological epochs, of the "King of the Herrings," and have been determined by their fossil jaws and spines. Ischiodus is found in the Lias. Chimæroid fishes are thus known to bave ranged from the Liassic epoch to the present time.

\section{Order 3.-FISH WITH SHINING SCALES. Ganoids.}

Sub-order.-Ganoids protected with plates of enamel. Placoganoids.

In America there is a fish known as the Bony Pike, of which there are three or four species. This is the Lepidosteus of naturalists; the name referring to the hard, bony scales with which they are covered.

The Polypterus also, of the African rivers, has the head covered with bony plates, and the body with strong 
scales. These are representatives-and there are few living representatives-of the great order of fishes, now nearly extinct, known to geologists as the Ganoidal fishes of the Palæozoic and Secondary rocks.

The arrangement of fishes both recent and fossil is a difficult and complicated business. Professor Huxley has lately published in the Memoirs of the Geological Survey (Decade 10), an important essay upon the systematic arrangement of the fishes of the Devonian epoch. In this edition of this little work, I have, however, preferred to continue the arrangement of Professor $\mathrm{O}$ wen, as it appears to me less complicated and aifficult to the young student, although I have not failed, when reading Professor Huxley's essay, to perceive the important views advocated in his arrangement of the order of the Ganoids.

Loricaria, one of the Siluridæ, or Sheat fishes, is a living fish, of which students should see a prepared specimen, if possible; and also the Sturgeon (Acipenser) which is a ganoid with plates. The sturgeon is a fish known even to country people that rarely visit the seaside. It is occasionally taken in our rivers, and exhibited in most country towns. The general form is that of a shark, but the body is covered with plates in rows. The Great Sturgeon of the Don and the Volga grows to the length of from twenty-five to thirty feet. The Common Sturgeon is about six feet long. Caviar is the roe of the sturgeon, and isinglass is made from its swimming-bladder. There is a transitional form of sturgeon, between the true ganoids and sturgeons, found in the Lias.

At present the Pteraspis Ludensis, a plate-covered ganoid fish, is the earliest known indication of a vertebrate animal.

The remains of several other ganoid fishes have been lately discovered in the rocks which lie as passage-beds between the Silurians and the Old Red sandstone.

We imagine that Professor Owen was ignorant of the discovery of a fish in Silurian deposits, vastly older than 
the beds in which Pteraspis truncatus was discovered near Ludlow, or he would have mentioned that discovery. The writer of these notes brought before the notice of the Malvern and Cotteswold Field Clubs (May, 1859), and again before the British Association at Aberdeen, a letter from Mr. Lightbody, of Ludlow, announcing the discovery of a fossil fish by Mr. Lee (Pteraspis Ludensis, Salter) in the Lower Ludlow rock of Leintwardine, Herefordshire. There cannot be a shadow of a doubt that the rock is the Lower Iudlow deposit of Murchison, and no one save the geologist, who knows the thickness of the Upper Ludlow shales and the Aymestry limestone, which intervenes between the site of the deposition of the Pteraspis truncatus and that of the Pteraspis Ludensis, can adequately comprehend how much the discovery of this little fish antedates the period during which fish have been now proved to have existed on this planet.

After those oldest known forms of fish (the Pteraspides of the Lower and Upper Ludlow deposits), we find the small defences of Onchus, \&c., in the beds immediately superimposed; and we have, at Ledbury and Ludlow, remains of the Cephalaspis (shield on the head), associated with Auchenaspis (shield on the neck), and remains of Crustaceans, Pterygotus, \&c. These are, without doubt, the lowest beds of the Old Red sandstone, and contain most of the earliest known forms of fish. The forms of Pteraspis and Auchenaspis are little known, and we await the researches of Professor Huxley, who is engaged in the examination of those antique fishes. They belong to the family of the Cephalaspides. Of the Cephalaspis, enough is known to enable the student to obtain a good idea of the shape. The bones of the head constituted a shield-like cuirass, terminating behind with three spines. The body seems also to have been protected by enamelled bands. As nothing is known of Pteraspis and Auchenaspis but the plates of the head and back, it is probable that only a portion of these fishes was cased in armour. 
The Pimelodi of the Ganges have a helmeted head, and a distinct dorsal plate of bone between the belmet and the dorsal spine. The late distinguished geologist Hugh Miller instances the Pimelodus Gulio, specimens of which are in the Elgin Museum, as probably illustrative of some of the ancient Ganoids. This Pimelodus is "a little strongly-helmed fish, with a naked body; and I was informed by Mr. Duff, on the authority of the gentleman who had presented the specimens to the IIuseum, that it burrowed in the holes of muddy banks, from which it shot out its armed head and arrested, as they passed, the minute animals on which it preyed."* The Cephalaspides belong to the Lower Old Red of Scotland and Russia.

"The genera Cephalaspis, Pteraspis, Auchenaspis, and Men. aspis," says Professor Huxley, "certainly form a family by them. selves, to which the title of Cephalaspidæ may be conveniently applied ; but the position of this fanily is not readily determinable. No one can overlook the curious points of resemblance between the Siluroids, Callichthys and Loricaria, on the one hand, and Cephalaspis, on the other, while in other respects they may be still better understood by the help of the Chondrostean ganoids. Compare, for example, Scapirhynchus with Cephalaspis, or the great snout of Pteraspis with that of Spatularia. I am inclined to place the Cephalaspids provisionally anong the Chondrostei, where they will form a very distinct family."

Again, with respect to the Coccosteus (or berry on bone), so well known to all readers of Hugh Miller's works, Professor Huxley says :-

"The remarkable genera Coccosteus and Pterichthys are those which, among all Devonian fishes, have been by common consent regarded as the most heteroclite and anomalous; some writers having gone so far, in fact, as to imagine that these hard-cased Vertebrates offered us a transition to the shelled Invertebrata.

"Nevertheless, I trust I shall be able to show that the one of these two closely allied genera-Coccosteus-is best, indeed, I may say only, to be understood, by comparing its bony shields with those which cover the roof of the cranium and the anterior part of the body of certain existing Siluroid Teleosteans.

* "Rambles of a Geologist," p. $28 S$. 
"For some years past I had suspected that the modern Siluroids presented more analogies to the seemingly aberiant Devonian fishes than any other members of the class Pisces, and from the examination of dried specimens, I had even pitched upon the Siluroid genus Clarias as that most likely to help me to understand Coccosteus; but it was not until my friend and former pupil, Mr. J. J. Monteiro, brought home for me from Congo some specimens of Clarias capensis preserved in spirits, that I was able to examine the osseous structure of that fish with sufficient care and thoroughness for the purposes of an efficient comparison."*

The Pterichthys, or winged fish, is a singular form among the Old Red ganoids.

"Of all the organisms of the system," wrote Hugh Miller, "one of the most extraordinary, and the one in which Lamarck would have most delighted, is the Pterichthys, or winged fish." "Had Lamarck been the discoverer, he would unquestionably have held that he had caught a fish almost in the act of wishing itself into a bird." "I fain wish I could communicate to the reader the feeling with which I contemplated my first found specimen. It opened with a single blow of the hammer; and there, on a ground of light-coloured limestone, lay the effigy of a creature fashioned apparently out of jet, with a body covered with plates, two powefullooking arms articulated at the shoulders, a head as entirely lost in the trunk as that of the ray or the sun-fish, and a long angular tail." $\uparrow$

We would also refer our readers to Professor Owen's account, + from which we learn that the Pterichthys possessed a small dorsal fin and a pair of ventrals, first observed by Sir P. Egerton, in addition to the pectoral flaps, which "indicate a certain power of swimming, though not with any great rapidity."

I am not aware that a single species of Pterichthys has been found in the Lower Old Red sandstone; but several species are known from the middle rocks of this formation, and two from the upper beds. The Upper Old

* Mem. Geol. Survey, 10th Decade.

+ "Old Red Sandstune," p. 72. + "Palæontclogy," p. 120. 
Red, of Farlow, Herefordshire, near the Clee Hills, has furnished a Pterichthys, which Sir P. Egerton considers to resemble most nearly the $P$. hydrophilus of Dura Den. This specimen was found by Mr. Baxter, of Worcester, associated with the scales of Holoptychius, and was presented by him to Sir P. Egerton. Other specimens have since been found by Mr. G. Roberts, and Mr. Jones, of Cleobury Mortimer, in the same locality.

The Farlow sandstones belong to the yellow group of deposits, which in many parts of Great Britain and Ireland underlie the lowest Carboniferous beds; and I have no doubt that they are equivalents of the celebrated Dura Den rocks of Scotland, the Upper Old Red sandstone.

Sub-order.-Ganoids with scales of enamel. Lepidoganoids.

Family.-Double-winged or finned fish. Dipterida.

If the reader should ever visit the neighbourhood of Cromarty, in search of fossil fish, and wander along the sea-shore towards the entrance to the bay, the "auld wives" will ask him, as he passes, if he is in search of "Miller's stone," of which that lamented geologist wrote as follows :-

"There rests in the neighbourhood of Cromarty, on the upper stratum of one of the richest ichthyolite beds I have yet seen, a huge water-rolled boulder of granitic gneiss, which must have been a traveller, in some of the later periods of geological change, from a mountain-range in the interior highlands of Ross-shire, more than sixty miles away. It is an uncouth-looking mass, several tons in weight, with a flat upper surface, like that of a table; and as a table, when engaged in collecting my specimens, I have often found occasion to employ it. I have covered it over, times without 
number, with fragments of fossil fishes, with plates, and scales, and jaws, and fins, and when the search proved successful with entire ichthyolites." *

I visited "Miller's stone" in company with one of his old friends, who loves the lore of the hammer and the "griesly fisch" of the "laithlie flood." The nodules containing the fish seem to be nearly exhausted; and although $\pi$ e obtained remnants of Osteolepis and Dipterus, we did not find the specimens by any means so abundant as when the bed was first discorered by the author of the "Old Red Sandstone."

The Dipterians are so called from the position and number of their fins. This family, which includes Osteolepis and Diplopterus, has a double anal as well as dorsal fin.

The Diplopterus has generally been considered a marked genus of the Middle Old Red. My friend Mrs. Hugh Miller informs me that it has lately been found associated with Cephalaspis Lyellii, in the Lower Old Red, by the Rev. Mr. Mitchell.

In their more striking characteristics, writes IIugh Miller, the three genera seem to have nearly agreed. "In all alike scales of bones glisten with enamel; their jaws, enamel without and bone within, bristle thick with pointed teeth; closely-jointed plates, burnished like ancient helmets, covered their heads; their tails were formed chiefly on the lower side of their bodies; and the rays of their fins, enamelled like their plates and scales, stand up over the connecting membrane, like the steel or brass in that peculiar armour of the middle ages whose multitudinous pieces of metal were fastened together on a groundwork of cloth."

Perhaps the most extraordinary haul, at one time, of the fishes of the Middle Old Red, was when, after the meeting of the British Association at Aberdeen, his Grace the late Duke of Richmond set on a number of

* "Old Red Sandstone," p. 105.

+ Ibid. p. 100 . 
workmen to quarry the nodules at Tynet Burn, near Fochabers, and afterwards to break them up. Hundreds of fossil fish were laid open to the light of day. I afterwards saw several of the specimens in the remarkable museum of fossil fish collected by Sir P. Grey Egerton, at Oulton Park.

\section{Family. Spined Fish. Acanthodii.}

The Cheirolepis, or scaly pectoral ; the Cheiracanthus, or thorny hand; and the Diplacantbus, or double spine, are ranked in this family. The scales are very small, and they have strong spines in the front of each fin. Hugh Miller's description of these fish is familiar to every geologist. Professor Owen gives a brief description, which will enable the geologist to distinguish the genera. Cheiracanthus has a single dorsal fin, situated in front of the anal. Acanthodes has the second dorsal fin situated behind the anal; Diplacanthus has two dorsals; while Cheirolepis has no spine in any fin, but possesses the minute scales of the family. Professor Huxley informs us that

"Cheirolepis contains fishes with moderate-sized heads and markedly heterocercal tails; with a single dorsal fin, a single anal, pectorals, and ventrals. The median fins are situated forwardly, the dorsal being over the posterior part of the anal; and the ventral fins are so forward as to be almost close to the pectorals. None of these fins are lobate. The body is covered with minute rhomboidal scales, which do not overlap one another; so that the skin has quite the aspect of shagreen."

\section{Family. Hollow-spined Fish. Coelacanthi.}

The Glyptolepis; or sculptured scale, and the Phyllolepis, leaf-scaled, with the Glyptopomus, have been hitherto ranked with the Coelacanths; so called from the hollow- 


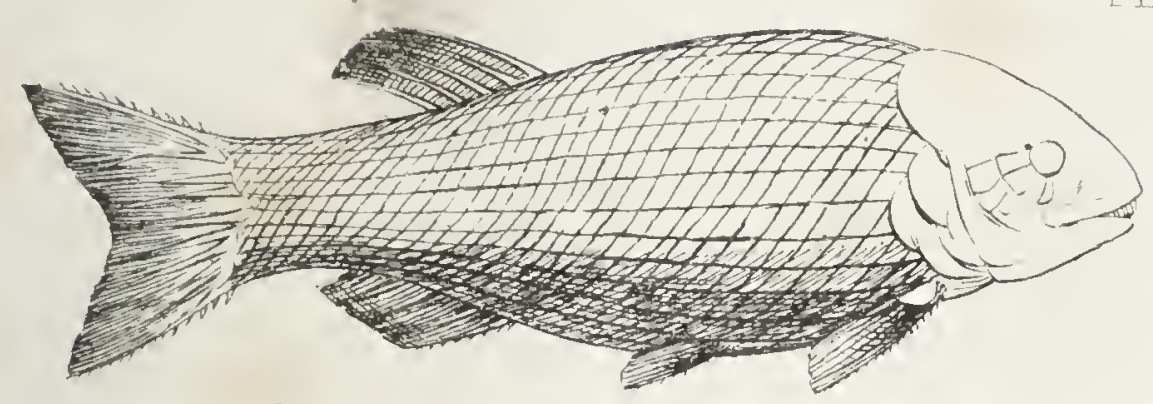

GANOID WITH HOMOULRCAL TAIL.

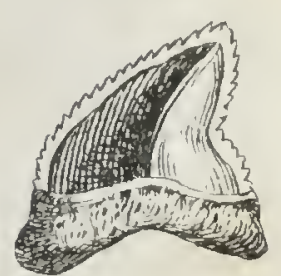

72

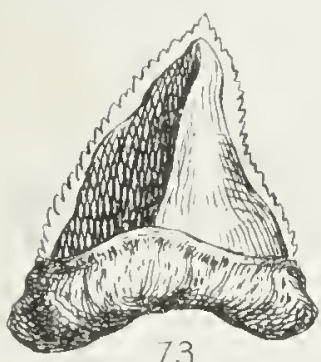

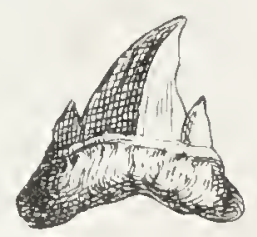

74

73
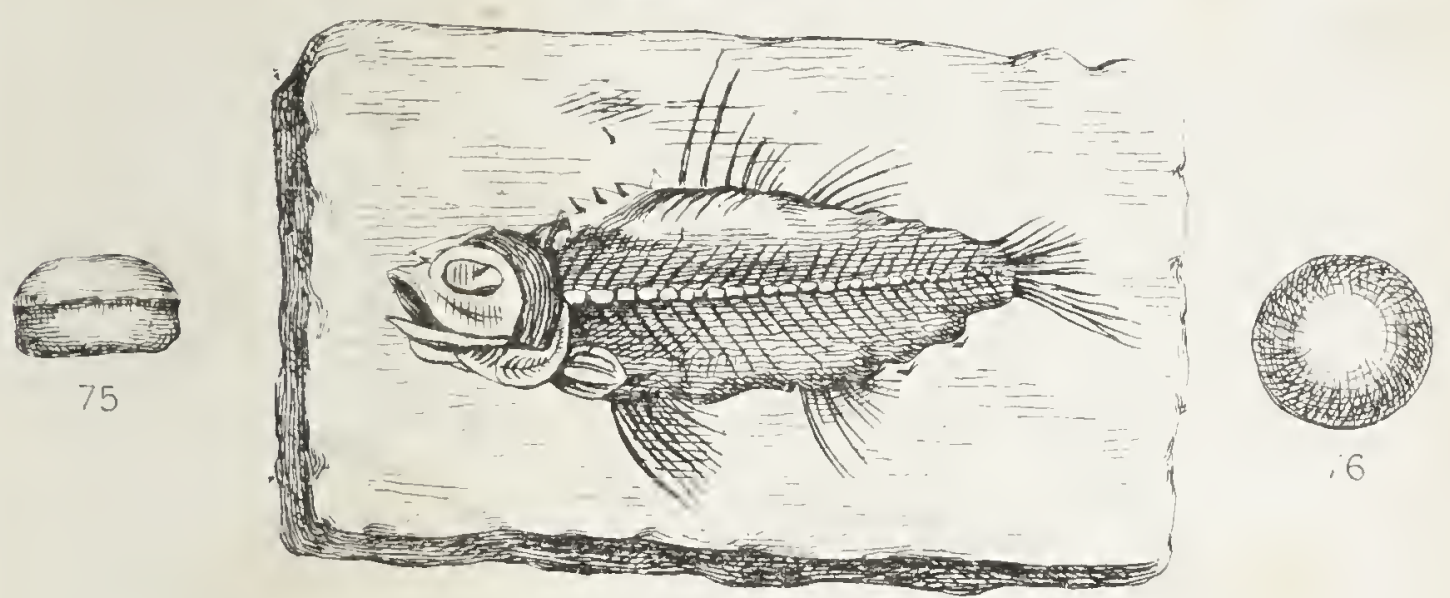

84 EXT,NCT CTENOID ; $\triangle: 4$

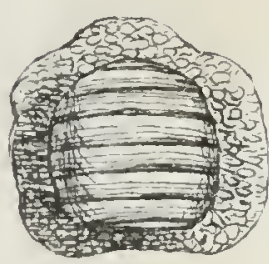

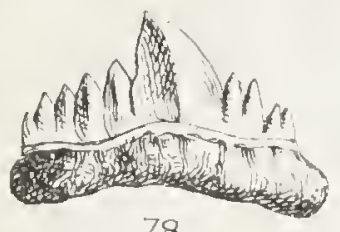

78

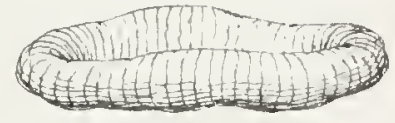

19
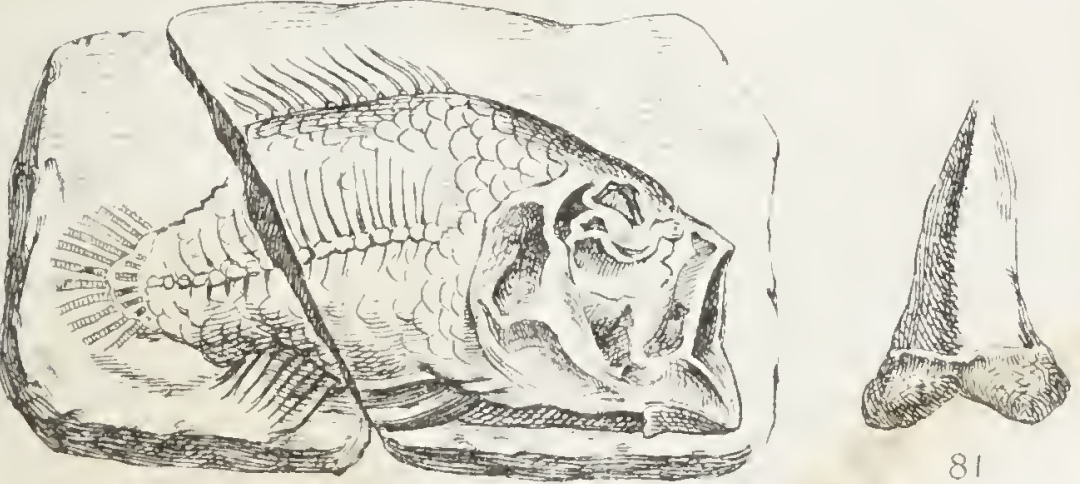

83 EXT:NCT CYC, 1:SH 

ness of their rays or spines. The Glyptolepis is found in the Middle Old Red of Scotland, and the Asterolepis in the Middle Old Red of Russia and Scotland. The other fish have been found in the Upper Old Red beds in Scotland only.

Glyptolemus, Glyptopomus, and Grroptychius have, according to Professor Huxley, truly homocercal tails and rhomboidal scales; while Glyptolepis possesses a heterocercal tail and cycloid scales. The Asterolepis, star-scaled, is found in that wonderful mausoleum of fish that lived and died during the epoch of the Middle Old Red sandstone, and left their skeletons in the bituminous schists of Caithness, and the fish-filled rocks of Cromarty, Tynet, and Lethenbar. Myriads of fish, "of forms the most ancient and obsolete," have left their relics in a former sea-bottom, rendering the beds bituminous, owing to the quantity of animal natter which they contain. Sir Roderick Murchison recommended these flags to be distilled for "stone oil," * that the people might trim their lamps with the animal matter of fish that lived myriads of ages ago.

The Asterolepis of Miller (Homosteus of Asmus) must have been a large Ganoid. "The head of the largest crocodile of the existing period is defended by an armature greatly less strong than that worn by the Asterolepis," and we learn that the structure of the fish was that peculiar half-armed, half-exposed structure to which we have already alluded. "It was a strongly. helmed warrior in slight scale armour; for the disproportion between the strength of the plated head-piece and that of the scaly coat was still greater than in that of Pterichthys."

Fer geologists felt more than Hugh Miller the necessity of cautious induction on the value of negative evidence in geological research. It was generally believed and taught that the Old Red sandstone fishes all possessed an interior skeleton of cartilage with an external

* "Siluria," 3rd edit. p. 203. 
covering of bone and enamel, and that fish with osseous vertebræ were not created in the days of the Old Red sandstone.

At the British Association at Oxford (1S60), Sir Philip Egerton produced a fossil fish discovered by Mr. Peach, which, he informs me, is allied to the Cœlacanths. This fish possesses osseous vertebræ, and is another example of the necessity of caution respecting negative evidence. Sir Philip Egerton has named the fossil Tristychopterus alatus.

Sub-Family. Wrinkled Fish. Holoptychida.

Professor Huxley places Holoptychius with Glyptolepis and Platygnathus, all having heterocercal tails and cycloidal scales, and has described the differences of the genera.

Sir Roderick Murchison ranks this family with the hollow-spined fishes the Colacanths. Professor Owen says "they are nearly allied to the Colacanthians, having, like them, but partially ossified bones and spines, the interior of which retained their primitive gristly state, and appear hollow in the fossils." There are splendid specimens of this bulky fish of the Old Red epoch in the museums of the Earl of Enniskillen and Sir Philip Egerton. The remains of the Holoptychius have been found in Germany, in Russia, in Scotland, in Herefordshire (at Farlow, associated with Pterichthys), and in Monmouthshire, near Crickhowel, by Sir R. Murchison and the late Rev. T. T. Lewis, in the Upper Old Red deposits.

Besides the wide range of this fish, it is worthy of remark that the Holoptychius nobilissimus of Scotland is found in Russia with marine shells, such as Productus, Terebratula, and Spirifer, and with Corals and Encrinites. So also is Coccosteus found in Germany, associated with 
marine fossils.* We thus learn that the Ganoids of the Old Red of Scotland were marine, while it seems probable that the fresh-water fishes of that epoch and the succeeding Carboniferous period were also Ganoids.

The remarkable fishes of Dura Den have been described by Dr. Anderson of Newburgh, $\uparrow$ who has discovered two or three new genera for the ichthyology of Scotland.

Professor Owen associates the Dendrodus, known by its large fossil teeth, with the Holoptychian family. The teeth of this large and predatory fish are found in a breccia at Scat Crag, near Elgin. They must have been washed out of some older deposit of the Old Red, as the remains of Permian reptiles have been washed into Triassic breccias. The Holoptychidæ pass into the Lower Carboniferous deposits, and $\mathbf{I}$ am not aware that any of the family have been found higher in the series of rocks.

\section{Family. Ancient Sea Fish. Palconiscida.}

The Ganoid fishes covered with enamelled plates (Placo-ganoids), that appear in the Lower Ludlow deposits in the shape of Pteraspis, die out during the long Carboniferous period that succeeded the epoch of the Old Red sandstone.

The Ganoid fishes covered with enamelled scales (Lepido-ganoids) range from the Old Red period to the Tertiary deposits; yet even in the Early Dawn epoch of present life, the Ganoids were reduced to a "lingering few." The Dipteronotus cyphus, from the Trias of Bromsgrove, Worcestershire, is apparently a Ganoid fish, with an intermediate form of tail.

Palæoniscus is a well-known genus of Ganoid fishes. Palæonisci are found in the Coal formations of Scotland. The Earl of Enniskillen and Sir P. Egerton possess

* "Siluria," 3rd edit. p. 383, \&c. † "Fishes of Dura Den." + See Quarterly Journal, Geological Society, 1854. 
specimens of a beautiful little Palæoniscus ( $P$. catopterus) from the Permians of Roan Hill, Tyrone; and the last known of the class was discovered by the Rev. P. B. Brodie, in the Upper Keuper sandstone of Warwickshire. This is described by Sir P. Egerton, under the name of $P$. supperstes. I have seen what I believe to be scales of this fish in the Keuper sandstone of Pendock, and Eldersfield, Worcestershire.

I have also been informed by Sir P. Egerton, that, as far as he is enabled to judge from a photograph, he cannot distinguish one species of fossil fishes lately discovered in the Paramatta beds of New South Wales, from Palæoniscus.

Family. Sauroid or Reptile-like Fishes. Saurichthyida.

Among the most striking objects in a collection of fossil fishes, are the jaws and teeth of a large Sauroid fish of the Carboniferous period, termed the Megalichthys by M. Agassiz. It must have been, verily, "a great fish ;" and it was truly excusable if, in the early days of ichthyological science, the teeth were mistaken for those of crocodiles. Professor Owen gives a long list of the fishes of this family, which appear to have been created during the Carboniferous epoch, and to have reached their zenith in the Triassic period.*

Family. Fish with equally-lobed Tails. Caturidae (Down Tails).

Few fishes with the equally-lobed or homocercal tail make their appearance until after the Palæozoic periods; and few fish with the homocercal tail have been found below the Lias.

$$
\text { * Owen's "Palæontology," p. } 139 .
$$


In rocks of the Oolitic epoch, the fish are Ganoids, but Ganoids principally with homocercal, instead of, as in the Palæozoic periods, with heterocercal, or unequallylobed tails.

Of thirty-three genera of fishes in the Lias, says Professor Owen, four only were represented in older strata, while the rest extend into the Upper Oolitic beds.

There is a bed of the Upper Lias known as the fish-bed. It contains many remains of Ganoid fishes, and also of insects and crustaceans. Those geologists who attended the meeting of the British Association at Cheltenham will remember a remarkably fine fish from the Marlstone and Upper Lias quarries at Stanley Hill, near Cheltenham; also the cracking of a nodule, containing a nearly perfect fish, in section $\mathrm{C}$, by Mr. Moore, the well-known geologist. These fish were Caturidæ, of the genus Pachycormus (thick body), of Agassiz. Fish of this family range from the Lias to the Chalk inclusive.

\section{Family. Thick-toothed Fish. Pycnodontes.}

These are an extensive family of Ganoid fishes, so called from their thick teeth, which are also round and flat, and adapted to the crushing of testaceous animals on which they fed. They are very like the Dapedius of the Lias, which is so named from the pavement-like arrangement of its rhomboidal scales; but Sir $P$. Egerton has satisfactorily determined that the difference of the dentition constitutes a different family. The Pycnodonts, in addition to other characteristics given by Sir P. Egerton,* have the small front teeth conical and single-pointed; in the Dapedidæ the front teeth are notched. The Platysomus of the Carboniferous deposits is the first known Pycnodont, and the last is one that lived in the epoch of Miocene tertiaries.

* Proceedings of the Geological Society, May, 1853, p. 276. 
Sir Philip Egerton informs me that he has received two specimens of fossil fish, and photographs of others, from the Paramatta beds of New South Wales, just alluded to; and that the specimens most resemble the genera Platysomus and Acrolepis, but are distinct.

The Lias of Barrow-on-Soar is famous for the wellknown Dapedius. I possessed a fine specimen from Sarnhill, near Tewkesbury, which I presented to the Earl of Enniskillen. It was found associated with the Pholidophorus Stricklandi, one of the Dapedian family, in the insect limestone of Brodie, a rock nearly at the base of the Liassic series of deposits. The Lias is the deposit in which most of this family are found. One genus (Semionotus) ranges to the Chalk formation.

Family. Rhomboidal-scaled Fish. Lepidotida.

The fish are Ganoids, covered with imbricated rhomboid scales, from whence the family has received the name. They are found in the Lias; and "one species (Lepidotus Maximiliani) lingers, after the commencement of the Tertiary period, in the 'calcaire grossier' of Paris," which belongs to the strata of the Dawn or Eocene period.

\section{Family. Slender-scaled Fish. Leptolepidce.}

These little Ganoids take their name from their slender scales. They are common in the Lias and succeeding groups of Oolitic rocks. It is hardly possible to crack open a portion of the yellow fish-bed of Dumbleton, Stanley Hill, and Churchdown, near Gloucester, without finding portions of one of the fishes of this family. Miss Holland, of Dumbleton, the Rer. P. B. Brodie, and other geologists, have obtained many perfect specimens from these Upper Lias deposits. Many years 
ago, on the first geological ramble I ever took, I knocked out one of these fish, nearly perfect, on the side of Dumbleton Hill. This settled my fate as a geologist!

The heterocercal Ganoids of the Palæozoic period were succeeded for the most part by homocercal Ganoids of the Secondary periods. Again, in the Tertiary periods, this once nearly predominant order of fishes gives place to the Teleostean (well-ossified) or bony fishes. In the Chalk epoch, fishes with bony internal skeletons become numerous; in the succeeding Tertiary epochs the Ganoids are scarce, and the osseous fishes take their place.

When we reflect on the immense number of fishes of this once nearly preponderant order that have died out, - of the very few that are left, we cannot but acknowledge the probable truth of much that Mr. Darwin advances in favour of the preservation of certain relics of ancient forms by the force of favourable circumstances. On an island, for instance, distant from a continent, the race of life will have been less severe, and there will have been. less modification and less extermination. "All fresh-water basins, taken together, make a small area compared with that of the sea or land, and, consequently, the competition between fresh-water productions will have been less severe than elsewhere; new forms will have been more slowly formed, and old forms more slowly exterminated. It is in fresh water that we find seven genera of Ganoid fishes, remnants of a once preponderant order; and in fresh water we find some of the most anomalous forms now known in the world, as the Ornithorhynchus and Lepidosiren, which, like fossils, connect, to a certain extent, orders now widely separated in the natural scale." ** 


\section{Order 4.-FISH WITH SCALES LIKF THE}

\section{TEETH OF A COMB. Ctenoidei.}

Ctenoid fish, or fish with pectinated scales, are divided into many families. None are more ancient than the Chalk formation. The common perch is a good type of the Ctenoid. The Climbing Perch of India (Anabas) is an example of extraordinary adaptation of structure. This fish not only creeps along the land, but even climbs trees by means of spines on its gill lids. If this fish was only known as fossil, how little would its habits have been suspected.

The Sea Gudgeon, or common Goby of the aquavivarium, is a Ctenoid, easy of examination; as also is the common Buli-head, or Miller's-thumb (Cottus gobio).

Specimens of these Ctenoid fish may be seen in the fish-house in the Gardens of the Zoological Society, and a handbook of reference, to which visitors may turn for information, has been prepared carefully by Mr. E. W. Holdsworth.

Professor Owen gives an engraving of an extraordinary Ctenoid fish from the Tertiary deposits of Monte Bolca. The dorsal fin is like the sail of a lugger, and the longpointed ventral fins might have been used as a couple of walking-sticks. This is the Semiophorus, and the genus is extinct. There must have been good perch-fishing during the Tertiary epochs, judging from the number of Ctenoid fishes that have been reckoned by ichthyologists as fossil.* Smerdis, Beryx, and many other genera, are Ctenoids.

Very fine specimens of a fossil Beryx (B. Lewesiensis) are found in considerable abundance in the chalk-pits of Kent and Surrey. They are called Johnny Dorys by the workmen. In some instances the capsule of the eye remains, and the membranes of the stomach are preserved. The Basse (Labrax lupus) is a marine Ctenoid. * See Morris's "British Fossils;" and Pictet's "Palæontology." 


\section{Order 5.-FISH WITH CIRCULAR SCALES. Cycloidei.}

The fishes of this order are distinguished by their rounded, smooth, and simple scales. There are many families, fossil and recent, as a glance at the list given by Professor Jukes, from Pictet's classification, will prove.* No Cycloid fish has hitherto been found in strata older than the chalk. Professor Owen figures a small turbot (Rhombus minimus) from the Tertiary deposits of Monte Bolca, and mentions that an extinct sole (Solea antiqua) has been found in Tertiary muds near Ulm. We find also that fossil fishes of the cod, mullet, carp, salmon, and herring families are found in the Tertiary formations, but are distinct from all known species; while from M. Pictet's list we gather that the tench, roach, dace, pike, anchovy, eel, and many others were abundantly represented in the Tertiary period.

The Osmeroides of the Chalk appears to be related to the smelt (Osmerus). This fish and the fresh-water cod, the burbot (Lota vulgaris), are, according to Mr. Holdsworth, in Regent's Park, as are also specimens of the tench, barbel, bream, gudgeon, and carp.

Professor Owen remarks as follows on the value of the evidence furnished by fisbes. "Many creatures living on land may never be carried out to sea; but marine deposits may be expected to yield adequate grounds for general conclusions as to the character of the vertebrate animals that swarmed in the seas precipitating such deposits." With the knowledge now possessed respecting the long Cambrian and Silurian epochs, it is very extraordinary, certainly, if fishes existed prior to the deposition of the Upper Silurian deposits, that their relics should not have been detected.

The knowledge that there is a law of gravity, through which law the motions of planets around their suns, and satellites around their planets, take place; and that the * Jukes's "Manual of Geology." 
law of the sun's attraction upon the planet is, that this attraction varies inversely as the square of the distance, is a knowledge that has raised the science of Astronomy to the proud position of a science that demonstrates great and irrefragable truths. If, after the great discovery of Newton, astronomers and mathematicians had squabbled, and fought, and used hard names and theological arguments as to why the law we find in operation must obtain, and had insisted on reasons for the law, as squared to the chronology and astronomy of the Jews, instead of accepting the knowledge of the law as a law, and working on the basis of that knowledge, astronomy would not have been the science it now is.

The force of gravity is a mystery, the history of creation is a mystery, life is a mystery, all God's laws are mysteries. They are laws, nevertheless, and it appears to me that if we let the reason why alone, and studied the effects of the laws more, we should be more likely to arrive at truth.

The examination of the principles of Palæontology and Biology has convinced philosophers that there is a "constantly operating, secondary, creational law;" while Owen has not hesitated to state his conviction in the "continuous operation of the ordained becoming of living things." With a knowledge of such laws as a basis, we look forward to a magnificent structure, yet to be reared by the investigations of geological, palæontological, and biological science; not indeed from theories as to whether certain inorganic atoms "flashed into life," but by the accumulation of FACTS, and by philosophical investigations of minute details connected with these established facts.

These notes are necessarily very imperfect, but if they induce others to study God's works for themselves, and to commence that study by the careful perusal of the evidence adduced respecting those works, the object I have had in view will be attained.

We finite men are allowed, even here below, to gather fruit within the illimitable expanse of truth, and to learn 
somewhat of the Creator's operations during the by-past eternity, although here we may never fully comprehend the history and its records. Truths are truths, and when they stand out before us distinct in all their teachings, encircled with the proofs of God's workmanship, I hold that we must accept them, no matter by whom they are contradicted.

There are individuals who are "colour-blind," and cannot distinguish black from white, or red from blue. There are, too, men who are mentally blind, and who do not, or will not, comprehend physical truths apparent to nine hundred and ninety-nine individuals out of a thousand. Such men are not to be blamed-their deficiencies are their misfortune, and not their fault; but I hold that the man who, in possession of his faculties, is mentally influenced by one mentally blind, is neither to be pitied nor excused.

Take a youth, and show him your collection of animals and fossils, your fossil fish, fossil plants, fossil shells, and your tusks, teeth, and jaws of extinct elephants. Tell him that those fossils never were portions of living animals, but are stone lies; tell him that those tusks and teeth never belonged to living elephants, but were created as fossils; that the Siberian mammoth, with the hair and wool on its body, never was a mammoth, and the birch and willow in its stomach never were willow and birch, but feigned abortions, serving the purpose of "an elaborate design to deceive and not instruct,"-and if that youth believe you, depend upon it he is mentally blind. Never induce him to take up the study of God's works in bygone epochs. He may do other work, but let him leave that alone for ever. $\mathrm{He}$ is no more capable of entering into that history than the "colour-blind" individual is of giving you a description of the golden sun, or the green leares, or the blue firmament. He will never understand those words of the Psalmist-"Thou takest away their breath, they die, and return to their dust. Thou sendest forth Thy spirit, they are created and Thou renewest the face of the earth." 


\section{CHAPTER V.}

\section{ON THE STRUCTURE OF BONE.}

IN the study of the structure and habits of extinct animals the naturalist is amongst vertebrate animals almost entirely dependent on their bones, and amongst the invertebrate animals the representatives of bone. The term bone is applied to the hard parts which form the skeletons of vertebrate animals. These parts being internal are called endo-skeletons. The invertebrate animals have their hard parts mostly outside, which are hence called exo-skeletons.

It is only animals supplied with skeletons or hard parts that have left their remains in the strata of the earth. Jelly-fishes, infusorial animalcules, slugs, and nudibranchiate mollusca are examples of animals without skeletons, and have, consequently, left no "old bones" for young naturalists to study. It is on this account that the vegetable kingdom has left so little record of its existence compared with the animal, most of the tissues having been destroyed before they could be embedded in the mud and other deposits of lakes, rivers, and oceans. Nevertheless, all the great classes of the animal and vegetable kingdoms are represented by their fossil remains.

The preservation of animal remains in rocks depends more on their chemical composition than on their physical structure. The hard parts of animals contain varying quantities of phosphate of lime, carbonate of lime, and fluoride of calcium. The carbonate of lime is found to be most abundant in invertebrate animals, whilst the phosphate of lime is found in largest quantities in the skeletons of vertebrate animals. The minute shells 
of the foraminifera, the skeletons of corals, and the shells of the various forms of mollusca, are principally composed of carbonate of lime. In the vertebrate animals, phosphate of lime takes the place of carbonate of lime, and is the prominent chenical characteristic. Fluoride of calcium, or Derbyshire spa, is found in small quantities in human bones and in those of the vertebrata generally. There is a curious fact connected with this substance, and this is, that the older bones are the more of it they contain. The bones of the fossil elephants brought by Dr. Falconer from the Sivalik Hills in India contain very large quantities of fluoride of calcium. It does not, however, appear that it was present in the skeletons of the animals whilst they lived, but that it has been gradually deposited in the bones by water containing the fluoride percolating through them. The quantities of substances found in the various kinds of skeletons may be seen in the accompanying table :-

CHEMICAL ANALYSES OF HARD PARTS OF ANIMALS.

\begin{tabular}{|c|c|c|c|c|c|c|c|}
\hline Substance. & Man. & Hawk. & Tortoise & Cod. & $\begin{array}{l}\text { Bone of } \\
\text { Cuttle } \\
\text { Fish. }\end{array}$ & $\begin{array}{c}\text { Red } \\
\text { Coral. }\end{array}$ & Oyster. \\
\hline $\begin{array}{l}\text { Phosphate of lime } \\
\text { Carbonate of lime } \\
\text { Other salts..... } \\
\text { Animal matter .. }\end{array}$ & $\begin{array}{r}60 \\
7 \\
2 \\
31\end{array}$ & $\begin{array}{r}64 \\
7 \\
2 \\
27\end{array}$ & $\begin{array}{r}53 \\
12 \\
2 \\
33\end{array}$ & $\begin{array}{r}57 \\
5 \\
4 \\
34\end{array}$ & $\begin{array}{c}\text { Trace. } \\
82 \\
18\end{array}$ & $\begin{array}{r}1 \\
83 \\
8 \\
8\end{array}$ & $\begin{array}{r}5 \\
88 \\
4 \\
3\end{array}$ \\
\hline & 100 & 100 & 100 & 100 & 100 & 100 & 100 \\
\hline
\end{tabular}

The animal matter of bones consists principally of gelatine, with a little oil. The oil is contained especially in the marrow, which is found in the cavities of the long bones. No sooner, however, are animals dead, and either covered up or exposed to the air, than the animal matter begins to decompose and is removed from the bone, the quantity of animal matter being thus in some 
measure the test of the age of the bone. In fossil bones the animal matter is in a large number of cases entirely removed, and in the case of the bones of whales and other animals found in the Red crag, a further deposit of phosphate of lime with other salts has taken place so as to render them more dense and compact than they were at first.

It is not always that bones are found so entire that the animals to which they belong can be at once identified. It hence becomes of great importance to be able to recognize the class to which an animal belongs by a fragment or small portion of bone. This can be done by the aid of the microscope.

If we take a portion of recent human bone, and grind it down till it becomes sufficiently thin to be examined by transmitted light under the compound microscope, we shall find that it presents a number of holes (Fig. 1, Plate XII). These are the openings of canals which traverse all parts of the bone, and are intended for the transmission of minute blood-vessels which carry the blood necessary to its nutrition. They are called Haversian canals, after Clopton Havers, an English naturalist, who first described them. In addition to blood-vessels, the larger of these canals contain marrow. The substance called marrow is composed principally of fat, and is found not only in the Haversian canals, but also in the hollow spaces of the long bones.

The size of the Haversian canals differs from the $\frac{1}{1000}$ of an inch in diameter to the $\frac{1}{200}$ of an inch. They are generally largest near the cavity of long bones, and smallest in the compact portions.

If we take a portion of recent bone, and submit it to the action of dilute hydrochloric acid, the phosphate of lime and other salts will be removed, and there will be left only the gelatinous or animal matter. When a portion of a bone thus treated is submitted to the microscope, there will appear a series of concentric rings around each Haversian canal. These constitute what is called the "lamellar structure" of the bone. In the 
midst of these lamellæ are numerous dark specks running in tolerably accurate circles round the Haversian canals. These dark specks were originally called "bone corpuscles," because they were supposed to be solid bodies in the midst of the bone. It is now, however, known that they are really minute cavities or vacuoles, and their dark appearance is given to them by the action of the light transmitted through them: they are hence called "lacunæ," or bone-cells (see Plate XII). To see these lacunæ well a higher power of the microscope is required than for seeing the Haversian canals. An ordinary compound microscope with a quarter-inch objective will enable any one to see them. On examining them with care, not only will the dark spots be seen, but there will be observed minute lines running from either side of the lacunæ. These dark lines are really little hollow canals, which have been called "canaliculi." The lacunæ and their canaliculi look like small insects running in circles round the Haversian canals. If these little canals are accurately examined they will be found to communicate with each other right and left, so as to constitute a communication between the Haversian canals and all the solid portions of the bone. There can be little doubt that the use of these canals is to convey nutrient fluid from the capillaries that run through the Harersian canals to the solid substance of the bone.

The lacunæ apparently represent the original bonecell, and the canaliculi the processes of the cells; whilst the lamellæ outside them are the cell-walls, which have been developed, probably, by materials supplied originally by the lacunæ and canaliculi.

The above description applies more particularly to the long bones. The same structures are apparent, but somewhat differently arranged, in the flat bones. If a bone of the skull is examined, it will be found to consist of three layers, - a compact layer on the outside, and a loose or spongy structure in the middle, and another compact layer on the inside. In the external and internal layers Haversian canals are seen which 
are smaller in the inner layer, but they are absent in the middle layer. All these layers present the lacunæ or bone-cells, which are larger in the outer layer than the inner layer. What is seen in the skull is also seen in the ribs, the scapula, and the bones of the pelvis.

The bones in all the vertebrate animals present the same general points of structure as those found in human bones. They differ, however, sufficiently in minor details to enable the observer to distinguish with tolerable accuracy whether a bone belongs to a mammal, a bird, a reptile, or a fish. This is a matter of very considerable importance, as it frequently happens in geological researches, where the object is to ascertain the nature of the animal life of a particular period, that only small portions of bone can be obtained, or that the fossil bones have been so exposed to the action of the sea as entirely to lose their form.

The portions of structure which are subject to most variation are the Haversian canals, the bone-cells, and their canaliculi. These points of structure differ, as we have seen, in the bones of the human skeleton, and they differ greatly in the various forms of mammals (Figs. 3, 4, and 5, Plate XI). This would be expected when it is recollected how different in size and how varied in functions are the bones belonging to the various species of mammalia, including the minute running mouse, the gigantic swimming whale, and the flying bat. At the same time it may be generally stated that the structure of the bones of mammalia is more nearly allied to that of the skeleton of man than to birds, reptiles, or fishes.

In Birds the bones are generally hollow, and the walls are thinner and more compact in structure than in the mammalia (Figs. 6 and 7, Plate XI). The bones, however, of walking birds, as the dinornis, the ostrich, and others, approach more nearly those of mammals than birds of flight. There is generally a larger quantity of earthy in proportion to the animal matter, so that frequently the bones of birds are as white and nearly as hard as ivory. 


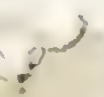

(4) 
On placing a section of a bone of a Bird under the microscope we shall find in the first place that the Haversian tubes are generally much smaller and more numerous than in man, and they freely anastomose or run into each other. They also run obliquely to the shaft, or even at right angles with it, so as to destroy the concentric layers of lacunæ, by which they are usually surrounded. When the bone-cells are examined they are found to be much smaller and more numerous in a given space than in the bones of the mammalia. The average length of the bone-cells of the ostrich is about the $\frac{1}{2000}$ of an inch, whilst their breadth is $\frac{1}{5000}$ (Fig. 6, Plate $\mathrm{XI}$ ). The canaliculi in the bones of birds are much fewer in number than those found in mammals. In the flat bones of small birds they are scarcely seen, and the Haversian canals are also absent in the same bones. In the larger birds, however, the Haversian canals and canaliculi are seen in the bones of the skull.

In Reptiles the bones are either hollow, spongy, or compact in their structure. Their specific gravity is less than that of either birds or mammals. The short bones of the turtles and tortoises are solid, and the ribs of snakes and serpents are hollow. If a transverse section of one of the long bones of a saurian reptile is made, it will be found, as compared with the bird or mammal, to have very few Haversian canals: not only are they proportionately few in number, but they are all of large size. On turning from the Haversian canals to the bone-cells, they will at once be seen to be even proportionately larger than the Haversian canals. They are also arranged somewhat differently from those in birds and mammals, as they present themselves both in a vertical and longitudinal position. On measuring the bonecells they will be found to be much longer than any found in birds and mammals. Those of the turtle measure the $\frac{1}{375}$ of an inch in length, whilst in the siren they are $\frac{1}{290}$ of an inch long. The canaliculi, like the bone-cells, are also of large size; but they differ in reptiles from birds, in the fact that they are much more numerous. 
These little canals also branch and bifurcate to a much greater extent in reptiles than in either birds or mam. mals. The bone-cells differ somewhat in form and size in the same species of reptile, and are longer in the long bones, and shorter and broader in the short bones (Figs. 8 and 9 , Plate XI).

The bones of Fishes differ in many respects from those of the other classes of vertebrate animals, and can seldom be mistaken for them. There is an absence of the concentric lamellæ around the Haversian canals. Sometimes the latter are absent altogether, and their place is supplied by numerous layers of bone-cells. In many instances the bones of fishes present nothing more than a series of ramifying tubes like the dentinal tubes found in the interior of the teeth of higher animals. In other instances true Haversian canals are observed, from which proceed minute tubes like the canaliculi of bone-cells. Others, again, present Haversian canals with bone-cells, and canaliculi surrounding them. The Haversian canals are generally larger than those of the bones of other animals. The bone-cells, when present, are remarkable for the four-sided figure which they present. The canaliculi are always few in number, and are of large size, and freely anastomosing with the canaliculi of other cells (Figs. 11 and 12, Plate XI).

The identity of the mode of formation of hard parts in the animal kingdom may be well seen in the structure of the scales of many fishes. If, for instance, we take the spine of a ray or the scales of the bony pike, and place them under the microscope, we shall find that they present bone-cells very nearly resembling in size and form those which are met with in the bones of fishes. The bone-cells of the scales are generally of a more decidedly quadrate form than those found in the bones of the internal skeleton.

If we apply now practically the knowledge obtained, by the aid of the microscope, of the structure of the bones of the four classes of vertebrate animals, we shall find that the size of the bone-cells will enable us to distinguish between the mammalia, birds, and reptiles. 
The $\frac{1}{2000}$ of an inch may be taken as the average length of the bone-cells in mammalia; they are much smaller in birds, and larger in reptiles, whilst those of fishes may be distinguished by their quadratic form. The size and form of the Haversian canals, with the size and ramifications of the canaliculi, will also be of additional assistance in determining the class of animals to which a bone belongs.

In the examination of the structure of the bone-cells, the late Professor Quekett was struck with the fact that the size of the bone-cells corresponds with that of the blood-globules in the various classes of animals. If a comparison is made between the size of the bone-cells and that of the blood-disks, there is certainly a general correspondence, which, although there exists no obvious relation between the two parts, is still of sufficient interest to be worthy of further observation.

The following table gives the measurement of the bone-cells of some animals after Professor Quekett, and of blood-disks after Professor Gulliver:-

\begin{tabular}{|c|c|c|c|}
\hline & & Bone-cells. & Blood-disks. \\
\hline $\operatorname{Man} . . . .\{$ & $\begin{array}{l}\text { Long diameter } \\
\text { Short do. }\end{array}$ & $\frac{\frac{1}{200} \overline{0}}{\frac{1}{6000}}$ & $\frac{1}{3200}$ \\
\hline Ostrich $\ldots\{$ & $\begin{array}{l}\text { Long diameter } \\
\text { Short do. }\end{array}$ & $\begin{array}{l}\frac{1}{2000} \\
\frac{1}{4500}\end{array}$ & $\begin{array}{l}\frac{1}{1650} \\
\frac{1}{3000}\end{array}$ \\
\hline Turtle.... & $\begin{array}{l}\text { Long diameter } \\
\text { Short do. }\end{array}$ & $\frac{\frac{1}{6 \pi 0}}{\frac{1}{5000}}$ & $\frac{\frac{1}{1230}}{\frac{1}{1880}}$ \\
\hline Eel $\ldots .$. \{ & $\begin{array}{l}\text { Long diameter } \\
\text { Short do. }\end{array}$ & $\frac{\frac{1}{500}}{\frac{1}{6000}}$ & $\frac{\frac{1}{1745}}{\frac{1}{2840}}$ \\
\hline
\end{tabular}

It should be observed with regard to this table, that many mammalia have larger bone-cells than man; that many birds have smaller bone-cells and smaller blooddisks than the ostrich; and that many reptiles have larger bone-cells and larger blood-disks than the turtle. It should also be observed that the general correspondence there pointed out is not without many exceptions. 
Besides the bones, there are other hard parts of animals found in a fossil condition. Teeth are even more likely to be preserved than bones; and in the instance of many animals, more especially of fish belonging to the shark tribe, the teeth are preserved when no other part of the animal is found. Teeth, however, are more constantly found entire than bones, and are not so likely to be found in fragments.

Two kinds of teeth are recognized by physiologists. First, dermal teeth, such as those of fishes and reptiles, and which are developed from the mucous membrane of the mouth, in the same way as hairs and scales from the epidermis of the skin; second, neural teeth, or those developed from cavities in the bones of the internal skeleton.

Teeth are much harder and more dense than bones. They are usually composed of three parts,-enamel, dentine, and bone or cementum. The enamel covers the outside of most teeth (Fig. 6, Plate XI). The dentine constitutes the interior of teeth, and is that part which in the tusks of the elephant constitutes ivory. The fangs of the teeth, and the interstices between the enamel in such teeth as those of the elephant, are composed of bony matter, or cementum (Fig. 3, Plate XI). In all these parts the teeth contain more earthy matter than the bones, as will be seen by the following table :-

COMPOSITION OF TEETH.

\begin{tabular}{|l|c|c|c|}
\hline & Dentine. & Enamel. & Cementum. \\
\cline { 2 - 3 } Animal matter & $28 \cdot 70$ & 3.59 & $29 \cdot 27$ \\
Earthy do. & 71.30 & 96.41 & $70^{\circ} \cdot 73$ \\
\cline { 2 - 4 } & $100^{\circ}$ & $100^{\circ}$ & $100^{\circ}$ \\
\hline
\end{tabular}

These parts present under the microscope different appearances. When a vertical section of the enamel of a tooth is placed under the microscope, it is found to be composed of a series of solid prisms or fibres, from $\frac{1}{5600}$ to $\frac{1}{3300}$ of an inch in diameter. When a transverse section of the enamel is made, these little fibres 
present themselves as hexagonal prisms. So that the enamel of the tooth is composed of a series of small columns closely packed together.

On placing a portion of dentine under the microscopi, it will be found to consist of tubes lying side by side. These tubes resemble the canaliculi of true bone, and are evidently modifications of the lacunæ, or bone-cells. They are called dentinal tubes, and are beautifully seen in thin sections of ivory. The smallest of these dentinal tubes are not more than the $\frac{1}{10000}$ of an inch in diameter. There are no Haversian canals in teeth, unless we regard the pulp-cavity in the interior of the dentine as a gigantic Haversian canal, into which both blood-vessels and nerves pass up.

The cementum, which is also called crustra petrosa, corresponds very closely in its structure with bone. It has frequently large lacunæ, and in some of the lower forms of mammalia, Haversian passages. It constitutes the fangs of all teeth, and in large compound teeth, like those of the molars of the elephant, it fills up the interstices between the enamel, and by its wearing more easily than the enamel, keeps the surface of the tooth always rough.

The dermal teeth present the same general structure, but the distinction into enamel, dentine, and cementum is not evident.

There are other hard parts of the animal skeleton found fossil, as the claws and horns of mammalia, the scales of reptiles and fishes, and the bills of birds, all of which present peculiarities which can alone be distinguished by the aid of the microscope. It will be, therefore, very evident that all students of Nature, who wish to become thoroughly acquainted with the structure and significance of "old bones," must provide themselves with that most important of all instruments of modern research, a MICROSCOPE. 


\section{-LOCALITIES IN THE BRITISH MUSEUM FOR} REFERENCE TO TYPICAL SPECIMENS.

A bbreviations.-Central Saloon (Cen. Sal.) ; Suuthern Zoolo. gical Gallery (South. Zool. Gal.); Mammalia Saloon (Mam. Sal.); Eastern Zoological Gallery (East. Zool. Gal.) ; Northern Zoological Gallery (North. Zool. Gal.) ; North Gallery (North Gal.).

\section{MAMMALIA.}

Order 1. Man, page 5.-Fossil woman, Nortl. Gal., room 6. Cave bones and skull, in ditto, in wall-case.

2. Monkeys and Lemurs, page 15.-Gorilla, in Cen. Sal.; skeleton of, in Mam. Sal., case 10. Monkeys, in Mam. Sal., cases 1-18. Lemurs and loris, cases 19 and 20. Fossil monkeys, in North. Gal., room 5 , case 13.

3. Carnivora, page 19. -Mam. Sal, cases 21-51. Fossil felidæ, in North. Gal., room 5, case 6. Fossil bear's, ditto, case 1. Walrus, in Cen. Sal. Seals, Mam. Sal., case 65.

4. Even-toed Animals, page 23.-Hippopotamus, in Soutl. Zool. Gal. ; fossil ditto, North. Gal., room 5, case 2; Anoplotherium remains, in ditto, case 3. Ruminantia, in South. Zoul. Gal., cases 1-30. Fossil camels, in North. Gal., room 3, case 7. Fossil oxen, in ditto, room 4, case 7. Irish elk, in ditto, room 6 . Fossil deer, in ditto, room 4 , case 6 . See also case 32 , room 4 , in North. Gal.

5. Odd-toed Animals, page 30.-The horse tribe, in South. Zool. Gal. 'Tapirs, in ditto, cases 10-16. Rhinoceros, in ditto, on Floor. Palæotherium, in North. Gal., room 5, case 3. Fossil rhiuoceros, in North. Gal., room 5 , wall-cases 5 and 7 .

6. Proboscidea, page 34.-One specimen of elephant, in

South. Zool. Gal.; fossil ditto, in North. Gal., room

6 , cases 5 and 6. Mastodon, in ditto.

7. Toxodontia, page 37.-North. Gal., room 6, case 10.

8. Mermaids (Sirenia), page 37.-Manı. Sal., on tops of cases.

Dinotherium, in North. Gal., room 6, case 2.

9. Whales, page 39.-North. Zool. Gal., room 3; fossil whales, in North. Gal., room 5, case 1.

" 10. Bats, page 40. Doorway cases, in Cen. Sal. 
Order 11. Insect-eating Animals, page 41.-Mam. Sal., cases 51 and 52 .

12. Toothless Animals, page 43.- South. Zool. Gal., cases 10, 15, and 16. Fossil Megatherium, in North. Gal., room 6. Scelidotherium, in ditto, case 3. Glyptodon, in ditto, case 11.

13. Guawiug Animals, page 45.-Mam. Sal., cases 66-\$1. Fossil, North. Gal., room 5, case 13.

14. Animals with Pouches, page 48.-Mam. Sal., cases 56-64. Fossil Diprotodon, in North. Gal., room 6. Stonesfield fossils, in North. Gal., room 5, case 13.

15. Monotremes, page 52.-South. Zool. Gal., case 15.

\section{BIRDS.}

Order 1. Rapacious Birds, page 55.-East. Zool. Gal., cases 1 35. White hawk, case 26 . Secretary bird, case 30.

2. Climbing Birds, page 57.-East. Zool. Gal., cases $36^{\circ}-$ 83 ; Nestor parrots in case opposite. Woodpeckers, $78-80$.

3. Perching Birds, page 59, cases 36-\$3.

4. Pigeons, page 61.-East. Zool. Gal., case 83, \&c. The dodo's foot, case 108 .

5. Poultry, page 65.-East. Zool. Gal., cases 89, 90, 91, and 93.

6. Coursers, page 67.-East. Zool. Gal., cases 107, \&c. Apteryx, case 108. Apyornis egg, ditto. Bones of Dinornis, room 6, in North. Gal.

7. Wading Birds, page 70.-East. Zool. Gal., cases 110-134.

8. Web-footed Birds, page 72. - East. Zool. Gal., cases 136-166. Great auk, case 150. Penguin, case 154. Fossil bird (Archæopteryx), in North. Gal., room 4, opposite case 6. Also see specimens in North. Gal., room 3 , case 11 .

\section{REPTILES.}

Orders 1-8, pages 77-92.-In the Nortl. Garl., rooms 3 and 4, are a magnificent series of the remains of fossil reptiles. The mud-fish (Lepidosireu), see page 79 , is in North. Zool. Gal., room 2, case 26. The fossil foot-prints of the Labyrinthodou, page 81, are in North. Gal., room 1. The great Enaliosaurs (sea reptiles), pages $81-86$, are in North. Gal., room 3, cases 4,5 , and 6 ; and room 4 , in ditto, cases $1-5$. The Dicynodon of Mr. Bain, page 86, is in room 3, case 2 ; as are also the Pterosauria or winged-lizards, page 87 . The Dinosaurs, page 90 , are in room 3 , cases 8 and 9 . 
[Orders 9-13, page 92-100, are living as well as fossil.]

Order 9, page 92, Crocodilia (recent specimens).--In North. Zcol. Gal., room 2, cases 24-26 ; fossil, North. Gal., room 3 , case 10 .

"10, page 93.-Lizards and monitors are in North. Zool. Gal., room 2, cases 1-10; fossil (Mosasaurus), page 94, North. Gal., room 3, case 1.

„, 11, page 94, Snakes and Serpents.-North. Zool. Gal., room 2 , cases $11-17$.

" 12, page 96. - The tortoises and turtles are in North. Zool. Gal., room 2, cases 18-23 ; fossil ditto, North. Gal., room 3, cuses 2 and 3 ; see also the model, in the Lobby, between the Mineral and Bird Galleries.

"13, page 97.-The toads and newts, \&c., are in North. Zool. Gal., room 2, case 26. Fossil foot-tracks of batrachians may be seen in North. Gal., room 1.

\section{FISHES.}

Order 1, page 103, Placoids.-Specimens of the recent sharks are in North. Zool. Gal., rooms 3 and 5, on the walls; ditto of the rays, in ditto, cases $41-43$; and the dogfishes, in room 3, case 40 . The remains of fossil fishes of this order are in North. Gal., room 2, in cases under the windows, and case 7 , at the end of the room.

2, page 103, Chimæroid Fishes._- "The King of the Herrings" is in North. Zool. Gal., room 3, against wall ; and the fossil chimæroids are in North. Gal., room 2, case 5 .

3, page 107, Ganoids.-The living ganoids. The bony pike is in the North. Zool. Gal., room 4, in the wall-cases; the sturgeon, page 108, in room 5, cases 1 and 2; and siluroid fishes, in room 4. Fossil fishes of this order are in North. Gal., room 2, in wall-cases, and arranged in different compartments.

4, page 122, Ctenoids. - The recent fish with pectinated scales are in North. Zool. Gal., wall-cases 1-13; and their fossil allies in the North. Gal., room 2, case 4, compartments 22-26.

5, page 123, Cycloid Fish.-Recent fish of this order are in North. Zool. Gal., room 4, wall-cases 15-19; and their fossil allies in the North. Gal., room 2, case 6, compartments $27-36$. 


\section{A D D E N A.}

Cyrena fluminalis, page 25.-An examination of Mrs. Strickland's cabinet, at Jardine Hall, leads me to doubt the occurrence of this shell in the Avon deposits.

Didunculus (or Gnathodon), page 62.-Two living specimens of Didunculus strigirostris have arrived lately in Sydney, and have been purchased by Dr. G. Bemnett for the Zoological Society.-Athencum, Nov. 14.

Dinornis, page 69.-A paper was read by Charles Clay, Esq., M.D., on Nov. 3, 1863, before the Philosophical Society of Manchester, "On the Existence of the Moa in New Zealand." Dr. Clay related two instances in which it had been seen on the Middle Island, "once on the coast near the gold-digging locality, and once on the banks of the Mockilinui river, about two miles from the coast, and twenty-five miles north of the Buller river. It is described as at least eight feet in height; the head as large as that of a full-grown calf, with a semicircular scarlet patch of about three fingers breadth under each eye; a thick short straight bill; its legs very thick and clumsy; the neck very short. In fact, the head, neck, and legs appeared out of proportion even with its huge body. The bird was feeding from the tops of the underbush, never attempting to feed from the ground, the shortness of its neck rendering such a process impossible. The neck for a considerable distance from the head downward was denuded of feathers, like the vulture, and the general colour of its plumage was of a dusky brown."

Pteraspis, page 108.-The scales of this fish have lately been discovered by Mr. Ray Lankester. They are rhomboidal. 


\section{N D E X.}

A BERDEEN, 113.

Acanthias, 104.

Acanthodii, 114.

A cerotherium, 34.

Accipenser, 108.

Acrodus, 90, 106.

Africa, monkeys of, 15, 17 ; leopards of, 20 ; hippopotamus of, 24 ; bedgehog of, 42 ; secretary bird of, 56 ; parrots of, 58 ; guinea-fowl of, 66 ; dicynodon of, 86 ; crocodiles of, 92 ; polypterus of, 107.

A gassiz, J'rof., 78, 101, 105, $106,118$.

Age of human race, 8.

Agouti, 47.

Albatross, 73 .

Albemarle isle, 94 .

Alca, 72 .

Alca impennis, 10.

Allies, Mr. Jabez, 33.

Alligator, 92, 96.

Alpaca, 29.

America, lion of, 20 ; bears of, 22 ; racoon of, 23 ; bison of, 26 ; buffalo of, 27 ; llama of, 29 ; horses of, 30 ; mammoths of, 63 ; toxodon of, 37 ; manatee of, 38 ; monkeys of, 44 ; edentates of, 44 ; capybara of, 47 ; coypu of, 47 ; parrots of, 58 ; footprints in, 79 ; iguana of, 91,93 , alligator of, 92 ; lizard of, 94 ; bony pike of, 107 .

Amphioxus, 101.

Anabas, 122.

Anderson, Dr., 117.
Andes, condor of, 55.

Animal kingdom, primary divisions of, 3 .

Annandale, ichnology of, 80 . \&c.

Annan, 22.

Anning, Mary, 88.

Anomodontia, 86.

Anoplotherium, 26.

Anteater, 43.

"Antiquity of Man," 10, 13, 22, 32.

Ape, 14.

Aptenodytes, 72.

A pteryx, 68.

AEpiornis, 69.

Arabia, monkeys of, 15 .

Archipelago, Indian, 15.

Architherium, 30.

Archegosaurus, 78.

Archæopteryx, 67.

Arctic regions, saurian of, 83 .

Arctomys, 47.

Argo fowl, 65.

Armadillo, 30, 43.

Artiodactyla, 23.

Asia, carnivora of, 20 ; hedgehogs of, 42 ; yavials of, 92 .

Asmus, 115.

Ass, 31.

Asterolepis, 115.

Atlantic Ocean, 12.

Auchenaspis, 109.

Audubon, M., 64.

Auk, 10 ; great, 72, 73 .

Aulacodus, 47.

Aurochs, 26.

Aust Passage, on Severn, 90. 
Australia, marsupials of, 48, 49 ; "Birds of," 56 ; lizards of, 85 ; cestracion of, 106.

Auvergne, fossil ruminants of, 29.

Aves, 54 .

Avon, drift of, 25, 27, 28, 33.

Avocet. 70.

Axoloth, 98 .

Aye-aye, 15.

BADger, 20, 21, 22.

Bain, Mr. A. C., S6.

Ballard, Mr., 34.

Banwell cave, 20, 21, 22, 34 .

Baphetes, 80.

Barrow-un-Soar, S3; fish of, 120.

Bard, Mr., 85.

Basse, 122.

Bats, 15, 40, 87 .

Batrachians, 79, 80, 97.

Bath, 106.

Bavaria, fossil bird of, 67 ; reptiles of, 78 .

Baxter, Mr., 112.

Bear, 8, 21, 24.

Beard, Mr. IV., 22, 34.

Beaver, 47.

Beckles, Mr., 92.

Bees, 46.

Beech forests, 9 .

Behring Straits, 38, 64.

Belcher, Sir Edw., 83.

Belideus, 51.

Bell, Mr., 40.

Berrow Hill, saurian of, 82.

Berry-bone, 110.

Beryx, 122.

Bettong of Tasmania, 51,

Big Bone Lick, mastodon of, 36 .

Bimana, 5.

Binney, Mr., 79, 97.

Binstead, Isle of Wight, 33.

Bipes, 95.

Birds, classification of, 54 .

Birds, structure of bone of, $1: 0$.

Bison, 8, 26.
Bizcacha, 47.

Blake, Mr. Carter, 30.

Blind-worm, 94.

Boa, 95.

Bolivia, macrauchenia of, 29.

Bone-bed, Lower Lias, 82.

Bone-cells, measurement of, 133.

Bone, structure of, 126.

Bonn, tadpoles of, 100 .

Bony pike, 107.

Borneo, flying foxes of, 41; crocodile of, 93 .

Bos longifrons, 27 ; primigenius, $10,25,27$.

Bosco's Den, 29.

Boucher de Perthes, M., 14, 31. Bourbon Isle, extinct birds of, 62.

Bowerbank, Dr., 88.

Bracklesham, fossil snake of, 95 .

Brazil, fossil monkeys of, 18 ; capybara of, 47 .

Bricklehampton, drift at, 25.

Brighton, elephant bed of, 35 .

British Association, 16, 109, 113, 119.

Brockeridge Common, 83 .

Brodie, Rev. P. B., 81, 87, $117,120$.

Bromby, Rev. C. H., 79.

Bromsgrove, trias of, 117.

Brongniart, M., 87.

Brontozoum, 56.

Bubulus, 27.

Buckland, Dr., 88, 90, 91.

$\longrightarrow, \mathrm{Mr} . \mathrm{F} ., 45$.

Buckman, Prof., 92.

Buenos Ayles, bizcacha of, 47 .

Buffalo, musk, $1 \pm, 27$.

Bufo viridis, 99.

Bulimus, 79.

Bull-frog, 99 .

Bull-head, 122.

Burmeister, Dr., 47.

Bushman, of Africa, 7.

Bustard, 68, 70 .

Buzzard, 57. 
Cainotherium, 30.

Cairo, 25.

Caithness, fossil fish of, 115.

Calao, 59.

Cælacanthi, 114.

Cambridge, British Association at, 36.

Cambridgeshire, fossil beaver of, 46.

Camel, 29, 32, 48.

Cambay, gulf of, 39 .

Cantal, fossil birds of, 72 .

Capercailzie, 10.

Capybara, $45,47$.

Carboniferous epoch, reptiles of, 8, 84; foot-prints of, 97 ; fish of, 105, 118.

Carcharodon, 105.

Cariama, 71.

Carniola, caves of, 98 .

Carnivora, 19.

Cartilaginous fish, 101.

Carolina, rivers of, 96 .

Cassowary, 68.

Castor, 47.

Cat, 20, 46, 62.

Cat of Mediterranean, 107.

Catarhini, 15.

Catoblepas, 26.

Catodon, 39.

Caves, 20.

Cephalaspis, 109.

Cervus, 26, 28.

Certhia, 60.

Cestracion, 103, 106.

Cetacea, 39.

Cetiosaurus, 100.

Ceylon, 6, 7, 15, 38 .

"Ceylon" Tennent's, 102.

Chalcides, 93.

Chalk, Kentish, 88 ; turtles of, 97, 105; ptychodus of, 106 ; fish of, 121 .

Chanting falcon, 56.

Charlesworth, Mr. E., 39.

Cheiracanthus, 114.

Cheirolepis, 114.
Cheiromys, 16.

Cheiroptera, 40.

Cheirotes, 93, 95.

Chelonia, 96, 100.

Cheltenham, fossil fish of, 119.

Cheshire, reptiles of, 81 .

Chili, vicuna of, 29 .

Chimæroids, 101, 107.

Chimpanzee, 17.

China, monkeys of, 15 ; cestracionts of, 106.

Chipping Norton, saurians of, 88, 90 .

Chœropotamus, 24.

Churchdown, fish of, 120.

Cincinnati, mastodon of, 36 .

Cinclus, 60.

Cirencester, museum of, 90 ; reptile eggs of, 92 .

Circus Jardinii, 56.

Cladyodon, 89.

Classification, 35 .

Clee Hills, pterichthys of, 112.

Climbers, 57.

Clive, saurian skull at, 86 .

Clothonia, 94.

Clover seed and cats, 46.

Cobra, 95.

Coccosteus, 110, 116.

Cock of the wood, 10.

Collnett, Captain, 94.

Coluber, 95.

Colubrine, 95.

Columbæ, 61, 64 .

Comberton, 25.

Condor, 55.

Coney, 34.

Coot, 70 .

Coralline crag, 13.

Cornwallis ship, sharks at, 104.

Corocoro, mines of, 29.

Couch, Mr., 102, 104.

Cougar, 48.

Cow-bird, 59.

Coypu, 47.

Crax, 65.

Creation, Vestiges of, 39. 
Cretaceous rocks, 84, 94, 100, 105.

Crickhowell, fish of, 116.

Croaker, of North America, 99.

Crocodiles, 89, 92, 96, 102.

Cromarty, fish of, 115.

Cromer, elephants of, 37.

Cropthorne, 27.

Crow, 59 ; fossil, 61.

Crystal Palace, Sydenham, 78, 98.

Cryptodont, 86.

Ctenacanthus, 105.

Ctenoids, 101, 122.

Ctenomys, 46.

Cycadaceous plants, 91 .

Cyclas, 90.

Cyclodus, 85, 93.

Cycloids, 101, 123.

Cypris, 90.

Cuckoo, 57, 59.

Cuculus canorus, 59.

Curassow, 65.

Curlew, 70.

Cursores, 67.

Cuvier, 3, et seq.

DANES, ANCIENT, 9.

Danger river, gorillas of, 17.

Dapedius, 119.

Darling downs, marsupials of, 50 .

Darwin, Mr., 29, et seq.

Dasyurus, 48, 51.

Davies, Rev. G. C., 60.

Dawn Epoch, 26, 30, 34, 47, $59,72,73,117$; meaning of, 11.

Dawson, Mr., 79.

Deer, 23.

Dendrerpeton, 79 .

Dendrodus, 117.

Denmark, ancient, 8, 9.

Deolin, Captain, 68.

Desman, 4:.

Devon, bone-caves of, 20 .

Didunculus, 62.

Digitigrada, 19.
Dimorphodon, 88.

Dinornis, 50, 69.

Dinosaurus, 90, 100.

Dinotherium, 38.

Diomedia, 73.

Diplacanthus, 114.

Diplopterus, 113.

Dipteronotus, 117.

Dipterus, 113.

Dissus, 47.

Divers, 72.

Dodo, 3S, 62 .

Dog, fossil allies, 20.

Dog-fish, 103, 104.

Dolomite, 89 .

Dolphin, 39.

Don, sturgeon of, 108.

Draco volans, 87.

Dromatherium, 51.

Dryopithecus, 18.

Ducie, Earl, 88.

Duck, 74, 105.

Duck-bill, 52 .

Dugong, 38 .

Duff, Mr., 110.

Dunfriesshire, footprints of, 97 .

Dumbleton, fish of, 120 .

Dura Den, fish of, 117.

Dicynodon, 86.

EAGLE, 56, 57.

Echidna, 52.

Echinostachys, 87.

Ectopistes migratorius, 64 .

Ecuador, marsupial of, 50 .

Edaphodus, 107.

Edderton, Rev. Mr. Joas, of, 90.

Edentata, 43.

Edinburgh, labyrinthodonts of, 81.

Egerton, Sir P., 82, 83, et $s \varepsilon q$.

Egypt, ancient, 8.

Eland, 27.

Elasmodus, 107.

Elasmotherium, 31.

Elephant, 14, 21，23，25，34, 37. 
Elephas melitensis, 36.

Elgin, saurian of, 89, 90 .

Elk, 8, 28.

Ely, saurians of, 85.

Emeu of New Holland, 68.

Enlydes, 96.

Enniskillen, Earl of, 28, 90, 116.

Eocene, meaning of, 10 ; fossils of, 11 ; palæotherium of, 33 ; marsupial of, 49 ; fossil bird of, $57,59,61$; monkey of, 18 ; turtles of, 97 ; fish of, 120.

Eopithecus, 18.

Eosaurus, 83.

Equus fossilis, 31 .

Essex, American ship, 39.

Estheria minuta, 90, 106.

Eudyptes, 74.

Europe, prehistoric inhabitants of, 8 ; bears of, 22 ; aurochs of, 26 ; sirenia of, 38 ; microtherium of, 44 : marsupials of, 49 ; tortoises of, 97.

Eyton, Mr. T. C., 86.

FALCกN, 56, 57.

Falconer, Dr., 13. et seq.

Falkland Isle, goose of, 73 .

Farlow, pterichthys of, 112.

Felis, 14, 20, 23.

Fieldfares, 60,61 .

File-fish, 102.

Fish-finned reptiles, 81.

Fishes, 101.

Fishes, structure of bone, 132 .

Flamingo, 73.

Florida, turtles of, 96.

Fochabers, fish nodules of, 114.

Forchhammer, Professor, 8.

Forbes, David, 29.

Fossil birds, 61.

Fox, 20 ; flying, 41.

France, human implements, 10 ; cave-remains of, 14 ; palæotherium of, 33 ; mosasaurus of, 94 .
Fraser, Mr., 50.

“Frazer's Magazine," 104.

Frigate-bird, 72 .

Frogs, 97, 98.

Frome, microlestes of, 42 .

Fulica, 71.

GABOON RIVER, gorillas of, 17 .

Galagos, 15.

Galapagos isles, finches of, 60 ; birds of, 93 ; tortoises of, 96 .

Galeopithecus, 15, 40.

Gallinæ, 65.

Gallus, 65.

Gallges, peafowl from, 66 .

Ganocephala, 77, 100.

Ganocephalous reptile, 100.

Ganoids, 107.

Ganoid fish, 78, 100.

Gavials, 92.

"Geologist," the, 89, 97.

Geological Survey, 108.

Geological Society, 117.

Georgia, turtles of, 96 .

Germany, dinotlierium of, 3S ; ganocephala of, 77 ; nothosaurus of, 84 ; placodus of, 85 ; toads of, 100 ; fossil fish of, 116 .

Gibbon, 18.

Giraffes, 26.

Glacial epoch, $12,28,32,36$.

Glass-snake, 94.

Gloucestershire, extinct mammals of, 25 ; pterosaurians of, 88 ; megalosaurus of, $y 0$.

Gluttons, 21, 23.

G'yptodon, 44.

Glyptopomus, 114.

Giathodon, 62.

Gnu, brindled, 26.

Goats, wild, 29.

Goatsucker, fossil, 61.

Goby, 122.

Godwit, 70.

Goldfuss, Professor, 73. 
Goose, upland, 73.

Gorilla, 16.

Gould, Mr., 50, 56, 65, 72.

Gower, caves of, 25, 29, 33.

Grallatores, 70.

Grebe, 73.

Greece, fossil monkeys of, 18 ; tortoise of, 96 .

Greensand, coprolites of, 40 ; crocodiles of, 92 .

Green toad, 99.

Grinshill, saurian of, 86 .

Grouse, red, 66.

Guanoco, 29, 44.

Guide book, 18, 24, \&c.

Guinea fowl, 60 .

Guise, Captain, 88.

Gulls, 73.

Gulo, 23.

Gunn, Mr., 37.

Gyroptychius, 115 .

Halmaturus, 50.

Hamster, 45.

Hares, 45.

Harkness, Professor, 90.

Harpy, 56.

Harrier, Jardine's, 56.

Hastings, Sir Charles, Dedication to, $\mathrm{v}$.

Hastings, footprints of, 92.

Haversian canals in bones, 128 .

Hawfinch, 61.

Hawk, 56.

Hawkins, Mr. W., 91.

Hawkbill turtle, 96.

Hedgehog, 42.

Hempstead, miocene of, 11.

Hen-island, 71.

Henslow, Professor, 40.

Herefordshire pterichthys, 112 ; fish of, 116.

Heron, 70.

Hilaire, M. St., 69.

Himalayas, pheasant of, 66 .

Hipparion, 31.

Hippocampus, 122.
Hippopotamus, 24, 36, 50.

Hitchcock, Professor, 80.

Hæmatopus, 71.

Holdsworth, Mr. E. W., 122.

Holl, Dr. B., 81.

Holland, Miss, 120.

Hollow-spined fish, 114.

Holocephali, 107.

Holoptychius, 112, 116.

Honey guide, 57.

Hooker, Dr., 66.

Hordwell, 97.

Horse, 23, 30, 31, 43.

Hughes, Mr., 50.

Humboldt, 33.

Huxley, Professor, 16, et seq.

Hybodus, 90, 106.

Hyæna, 19, 20, 23, 26.

Hylaosaurus, 91.

Hyperodapedon, 89.

Hypsiprymnus, 51.

Hystrix, 47.

IBEX, 8.

Ibis, 71 .

Ichnology, 80 .

Ich thyopterygia, 81.

Ichthyosaurus, 82, 100.

Iguana, 91.

Iguanodon, 91.

India, miocene remains of, 12 ; monkeys of, 15,18 ; wild asses of, 31 ; dinotherium of, 39 ; parrots from, 58 ; tortoise of, 97 ; perch of, 122.

Insectivora, 41.

Ireland, volcanic action in, 31 ;

Reeks of, 99 .

Isaac, Mr., 50.

Ischiodus, 107.

Isle of Wight, miocene of, 11 ; palæo therium in, 33.

Italy, tortoise of, 96 .

JACANA, 70.

Jaguar, 20, 48.

Jamaica, rain-bird of, 59 . 
Japan, batrachian of, 99 ; monkeys of, 15.

Jardine, Sir W., 22, et seq.

Jardine's harrier, 56.

Java, parrots of, 58; gallinæ of, 65 .

Joas, Rev. Mr., 90.

Johnny Dory, 122.

Jones, Dr. Stead, 85.

Jones, Mr. Rupert, 90, 106.

Jerboa, 47.

Jukes, Professor, 65.

Jura, Swiss, 18.

KaKAUIE, 74.

Kangaroo, 48, 50, 51.

Kempsey, drift at, 25 .

Kenilworth, fossil teeth at, 81 .

Kent, chalk lizards of, 88 ; fish of, 122 .

Kentucky, mastodon of, 36 ; caves of, 103.

Keuper beds, 81, 106.

Kiang, 31.

Killarney natterjack, 99.

Kimmeridge clay saurian teeth, 85.

King of herrings, 107.

King, Dr., 79.

Kingsley's, Professor, "Water Babies," 14 .

King, Rev. S. G., 37.

Kingston, kangaroo at, 51.

Kite, 56.

Knot, 70.

Knowsley, kangaroo at, 51.

Kordofan, giraffe of, 27 .

LABRAX LUPUS, 122.

Labyrinthodonts, 79, 100.

Lacertilia, 93.

Lagomys, 46.

Lagopus, 66.

Lagostomus, 47.

Lanark, 111.

Lammergeyer, 55 .
Lanius collurio, 60.

Lankester, Dr. (see dedication). Lankester, Mr. Ray, 52, 136.

La Plata, woodpecker of, 57.

Lari, 73.

Lark, 59.

Lartet, M., 34.

Lawford, fossil bone of, 74 .

Ledbury, fish of, 105, 109.

Lee, Mr., 109.

Leech fossil, 106.

Leguat, M., 63.

Leintwardine, Pteraspis of, 109.

Lemur, 15, 18, 40.

Lena river, rhinoceros of, 33.

Leopard, 20.

Lepidosiren, 21, 78, 98.

Lepidosteus, 103, 107.

Lepidotus, 90, 120.

Leptolepidæ, 120.

Lewis, Rev. T. T., 116.

Lias, coprolites of, 40 ; lizards of, 82,87 ; fishes of, 100, 102, $105,106,108$.

Lightbody, Mr., 109.

Limosa, 70.

Lindley, Dr., echinostachys of, 87.

Linksfield, 89.

Lion, 14, 20, 21, 23, 48 .

Lithornis, 57 .

Lizard, 84, 93.

Llama, 29, 48.

London, rhinoceros remains near, 33.

Longdon marshes, shrikes of, 60.

Lophodus, 106.

Loricaria, 108.

Lubbock, Mr.

Ludlow, bone-bed of, 104 ; lower fish of, 109.

Lyell, Sir Charles, 10, et seq.

Lyme Regis, dimorphodon of, 88.

Lyon, Captain, 22.

Lyttelton, Lord, bustard of, 70 . 
M.ıCKie, Mr., on fossil birds, 61,88 ; on turtles, 97.

Macrauchenia, 29.

Macropus, 50 .

Macrotherium, 44.

Madagascar, lemurs of, 15; hedgehog of, 42 ; parrots of, 58 ; fossil eggs of, 69.

Maestricht, mosasaurus of, 94 .

Malay tapir, 34.

Malta, elephant of, 36 .

Malvern, ouzel at, 61 ; Field Club, 109.

Marnmalia, orders of, 5 .

Mammalia, structure of bone of, 130.

Mammoth, 8, 23, 24, 27, 35, 50.

Man, 5, 32 .

Man, Isle of, elk of, 28.

Manatee, 38, 39.

Manis, 44.

Mantell, Dr., 91 ; Mr. W., 58, $69,71,74$.

Marmot, 45, 47.

Marsh, Mr., on eosaurus, 83.

Marsupials, 42, 48.

Martin, 59.

Mastodon, 36.

Mauritius, pigeon of, 38 .

Mediterranean, turtle of, 96 ; flamingo of, 73 .

Megaceros, 28.

Megalich thys, 118.

Megalosaurus, 88, 90.

Megatheroid, 43, 44 .

Melierax musicus, 56.

Melville on Dodo, 62.

Mergulus, 73.

Mermaids, 37.

Mexico, batrachian of, 98 .

Meyer, Von H., 78.

Microlestes, 42, 51 .

Microtherium, 30.

Miller, Hugh, Mr., 79, 110, 114, 115.

Miller's thumb, 122.

Miocene, meaning of, 10 ; boar of, 25 ; ape of, 18 ; carnivore of, 20 ; ruminants of, 29 ; dinotherium of, 38 ; rodents of, 48 ; eagle, and eggs of, 57 ; thrush of, 61 ; partridge of, 67 ; fish of, 119 ; frogs of, 100 .

Mocking-bird, 59, 61.

Modiola. 90.

Mole, 42.

Moluccas, cassowary of, 68.

Mongolian, 7 .

Monitors, 84, 93.

Monkeys, 15, 18.

Monotremes, 48, 53.

Monte Bolca, semiophorus of, 102 ; fish of, 122.

Moore, Mr., 42, 83, et seq.

Moorhen, 71.

Mooruk, 68.

Moray Firth, 90.

Morris's "British Fossils," 122.

Mosasaurus, 97.

Mouse, 45, 46.

Murchison, Sir R., 89, 115, 116. Muschelkalk, nothosaurus of, 84 ; placodus of, 85.

Musk buffalo, 27.

Mylodon, 44.

Myopotamas coypus, 47.

Myrmecobius, 42.

Mytilus, 90 .

Natrix torquata, 95.

Natterjack, 99.

Nature, the study of, 1.

"Natural History Review," 8.

Nebraska, anchitherium of, 30 .

Negro, 7.

Nestor hypopolius, 58 .

New Guinea, papous of, 8.

New Holland, emeu of, 68.

New red sandstone, microlestes of, 42 ; impressions in, 81 ; rhynchosaurus of, 86 .

Newts, 33, 97. 
Newton, Sir I., 124.

New World, monkeys of, 15.

New Zealand, fossil birds of, 69 .

Nice, shark of, 104.

Nightingale, 59.

Nile, White, hippopotamus of, 24 ; turtle of, 96.

Niphon, batrachian of, 99 .

Non-ruminants, 23.

Norfolk, elephants of, 37 ; beaver of, 46.

Norfolk Isle, parrots of, 58 .

Nothosaurus, 84.

Notornis, 71.

Nova Scotia, reptiles of, 79 ; baphetes of, 80 .

Numenius, 71.

Nuthatches, 57, 60 .

OCELOT, 48.

Old red sandstone, ganoids of, 78, 108 ; fish spines of, 105 ; fish of, 113.

Old World, monkeys of, 15, 29.

Ombersley, fossil plants of, 87 .

Onchus, 105.

Oolite, marsupials of, 52 ; fossil feathers of, 57 ; fossil bird of, 67 ; megalosaurus of, 90 ; fish of, 119.

Oomany, veddahs of, 7 .

Ophidia, 94.

Opossum, 44, 48, 49, 51 .

Oreosma, 103.

"Origin of Species," 121.

Oriolus, 60.

Ornithorhynchus, 52, 121.

Orodus, 106.

Osmeroides, 123.

Osprey, 57.

Osseous fish, 101.

Osteolepis, 113.

Ostrea beds, 82.

Ostrich, 50.

Otis, 68, 70.

Ouzel, water, 60.

Owen, Professor, 3, et passim.
Owl, 56.

Oxford, meeting of British Association at, 16, 116; Stonesfield slate of, 51 ; saurians of, 88.

Oyster-catcher, 71 .

Pachycormus, 119.

Pachydermata, 32, 33.

Palæoniscus, 117.

"Palæontology," 3, 26, 83, 97, $100,116,118$.

Palæophis, 95.

Palæosaurus, 89.

Palæotherium, 33, 34.

Palæozoic rocks, ganoids of, 108 .

Pallas, 31, 101.

Palapteryx, 69.

Palmipedes, 72.

Panther, 48.

Paradise, bird of, 59.

Paraguay, 46.

Paris, tertiaries of, 26 ; mammals of, 49 ; mosasaurus of, 57.

Parker, Rev. W., 25, 33.

Parrots, 57.

Passenger pigeon, 64.

Passeres, 59.

Patagonia, guanoco of, 29.

Peach, Mr., 116.

Peafowl, 66.

Peccary, 24, 44.

Pelias beras, 95.

Pelican, 74.

Penarth-on-Severn, bone-bed of, 90.

Penguin, 72.

Pelmian, reptiles of, $80,84,89$;

footprints of, 97 ; fish remains, 105.

Perchers, 59.

Perch, 122.

Perim Isle, dinotherium of, 39.

Perissodactylii, 30 .

Persia, wild asses of, 31.

Peterhead, whalers of, 22.

Petrel, 73. 
Pezophaps, 63.

Phacochærus, 24.

Phalangista, 51.

Phascolarctos, 48.

Phascolomys, 48 .

Phasianus giganteus, 65 .

Pheasant, 66.

Philip Isle, parrots of, 58.

Phoca vitulina, 23.

Phœnicopterus, 73.

Phyllolepis, 114.

Physeters, 39.

Pictet's "Palæontology," 122.

Pictou, N. Scotia, reptiles of, 8').

Pig, 23, 32, ; water, 47 ; ground, 47.

Pigeons, 64, 65.

Pinelodus, 110.

Pinnigrada, 19, 23.

Pintado, 66.

Pisces, 101.

Pistosaurus, 85.

Placodus, 85.

Placoganoids, 107.

Placoids, 101, 103.

Plagiaulax, 52.

Plagiostomi, 103.

Plantigrada, 19, 21.

Platygnathus, 116.

Platyrhini, 15, 44.

Platysomus, 119.

Plesiosaurus, 84, 90.

Pleuracanthus, 105.

Pliocene, hippopotamus of, 25 ; tortoise of, 97 ; frogs of, 100 ; meaning of, 10, 12 ; whales of, 40 ; post, 11, 13, 20, 27, 59, 67.

Polar bear, 22.

Polecat, 52.

Polypterus, 107.

Polyptychodon, 85 .

Porcupine, 42, 45, 47 .

Porphyrio, 71.

Port Jackson shark, 106.

Portland oolite, saurus of, 92 ; turtles of, 97 .
Post tertiary, 10, 30, 31 .

Poultry, 65.

Press, 42.

Prestwich, Mrr., 14, 31.

Proboscidea, 34.

Procellaria, 73.

Procyon, 23.

Proteus, 98.

Protosaurus, 84, 100.

Pseudopus, 94.

Pteraspis Ludensis, 108, 117.

Pterichthys, 111, 115.

Pterodactyle, 87.

Pterois, 103.

Pterosauria, 87.

Pterygotus, 109.

Ptycacanthus, 105.

Ptychodus, 106.

Purbeck beds, marsupials of, 42 ,

52 ; saurians of, $90,94$.

Puma, 20.

Pupa in sigillaria, 79.

Pycnodonts, 119.

Pygopterus, 78.

Pyll Hill, bone-bed of, 90 .

Pythons, 95.

Quadrumana, 15.

Quagga, 31.

RABBIT, 45 .

Racoons, 21, 23.

Rail, 70 .

Rain-bird, 59.

Ramsay, Professor, 13.

Rana, 99.

Raniceps, 79.

Raptores, 55.

Rats, 45.

Raven, SS.

Rays, 103, 105.

Réaniur, M., 105.

Red crag, 13; Irish deer of, $2 S$; coprolites of, 39 ; shark of, 105.

Red fire-fish, 103. 
Redland, thecodonts of, 89.

Redmarley, 21.

Redwing, 61 .

Reeks of Killarney, 99.

Reindeer, 14, 28.

Reinhardt, Professor, 63.

Remora, 102.

Reptiles, orders of, 76,77 ; structure of bone of, 131 .

Rhamphorhynchus, 88 .

Rhea, 68.

Rhinoceros, 10, 14, 23, 24, 27, $31,33,37,50,59$.

Rhombus minimus, 123.

Rhophalodon, 84.

Rhynchosaurus, 86.

Richmond, Duke of, 113. .

Riley, Dr., 89.

Roan Hill, fossil fish of, 118.

Roberts, Mr. G., 28, 112.

Robin, American, 61.

Rock veddahs, 6,7 .

"Rocks of Worcestershire," 28.

Rock pigeon, 64 .

Rodriguez Isle, birds of, 62.

Rodentia, 16, 45 .

Rondeletius, 104.

Rorqual, 39.

Ruff, 70.

Ruminants, 21, 26, 32.

Russia, old red of, 110, 115; fossil fish of, 116 .

Rutimeyer, M., 18, 22.

Rytina, 38, 64 .

SAARBROCH coalfield, 78.

Salamander, 81, 97, 98.

Samoan Island, pigeon of, 62.

Sand lizard, 93.

Sardinia, tortoise of, 96 .

Sarnhill, reptile of, 83 ; fish of, 120.

Sarsden, pterosaurians of, 88 .

Saurian's grave, 82.

Sauriclithyidæ, 118.

Sauropterygia, 83.
Scat crag, fossil fish of, 117.

Scincus marinus, 93.

Science, theology of, 6 .

Scinques, 95.

Sclater, Dr., 18, 20, 22, ct pas. sim.

Scotland, miocene remains of, 11 ; bear of, 22 ; cephalaspis of, 110 ; fish of, 115.

Sea-gudgeon, 122.

Seal, 23.

Secondary rocks, 107.

Secretary bird, 56, 59 .

Selsby Hill, 90.

Semiophorus, 102, 122.

Seps, 94.

Shark, 11, 103, 105.

Sheat fishes, 108.

Sheep, 28, 29.

Shells, freshwater, 25, 28.

Sheppy, fossil bird of, 57, 74 ; serpent of, 95 .

Shrew mouse, 41.

Shrewsbury, rhynchosaurus of, 86.

Shrike, 59, 60 .

Siberia, rhinoceros of, 33 .

Sieboldia maxima, 99 .

Scelidotherium, 44.

Sigillaria, skeleton in, 79 .

"Siluria," 115.

Silurian rocks, 188.

Siluridæ, 108.

Sirenia, 37.

Sitta, 68.

Skate, 105.

Sloth, 30, 43, 150.

Slow-worm, 94.

Smerdio, 122.

Smith, Adam, 101.

Smith, Professor Piazzi, 34.

Snake, harmless, 95.

Socket-tooth lizards, 89.

Sole, 123.

Solenhofen, fossil bird of, 67 .

Solipedia, 30 .

Somerset, caves of, 20, 22. 
Sphagodus, 104.

Spalacotherium, 42.

Spaniards, 30.

Sparrow, 59.

Spitzbergen, ark of, 73 .

Spoonbill, 70.

Squirrel, 45, 47 .

Stag, 8.

Stagonolepis, 89.

Stanley hill, fish of, 12.

Steenstrup, Professor, 8.

Stereognathus, 52.

Still bird, 70.

Stonesfield, marsupials of, 5] ; saurians, 88, 90 .

Sting-ray, 105.

Strepsirhini, 15.

Strickland, Mr. H., 25, 27, et seq.

Strigops, 58.

Struthio, 67.

Stubton, 51.

Stumptailed lizard, 93.

Sturgeon, 103, 108.

St. Hilaire, M., on fossil eggs, 69.

St. John, Mr., 41, 93.

St. Petersburg, rhinoceros of, 33 ; mammoth, 34.

St. Peter's mountain, mosasaurus of, 94.

Suffolk, cetacen of, 39 ; sharks, teeth of, 105.

Suidæ, 24.

Sumatra, tupaiia of, 42 ; parrots of, 58 ; poultry of, 65 .

Surgeous, College of, 19, 50.

Surinam toad, 99.

Surrey, fish of, 122.

Sussex, iguanodon of, 91 ; mosasaurus of, 94.

Swallow, 59.

Swan, 74.

Swanage, fossil eggs of, 92.

Swift, 59.

Switzerland, discoveries in, 8.

Sydenham, palace at, 91 .

Syria, bear's of, 22 .
Tadpole, 97, 98, 100.

Takahi, 71.

Talegalla, 66.

Tanrec, 42.

Tapir, 11, 33, 34, 44.

Tasmanian devil, 48, 51.

Taylor, Mr. A., 92.

Telerpeton, 89.

Tennent, Sir Emerson, 6 ; "Ceylon" of, 102.

Terns, 74 .

Testudo, 96, 97.

Tetrao urogallus, 10.

Tewkesbury, drift at, $28,40,60$.

Thames, beaver of, 46 .

Thecodontia, 89 .

Theology, science of, 6 .

Thibaut, M., 27.

Thibet, bears of, 22 .

Thorn, Rev. Mr., on ouzel, 61.

Thylacinusi, 48, 51, 52 .

Tiedemann, 16.

Tierra del Fuego, petrel of, 73.

Tiger, 20, 48.

Tigris, 20.

Toads, 97.

Tomes, Mr. R. F., 50.

Torpedo, 105.

Tortoise, 96.

Toucall, 57.

Toxodontia, 37.

Trachydosaurus, 93.

Tree creepers, 57, 60.

Tree frog, 99.

Tree lizard, 79.

Trias, plesiosaurus of, 84 ; bone. beds of, 89 ; labyrinthodonts, 100 ; fish of, 105.

Tringa, 70.

Trionyx, 96, 97.

Tristan d'Acunha, hen of, 71.

Tristychopterus, 116.

Triton, 93, 99.

Trogonoph, 95.

Trogontherium, 46.

Trygon, 105.

Tupaiia, 42. 
Turbot, 123.

Turdus, 61.

Turkey fowl, 65 .

Turtle, 11, 96, 97.

Tynet Burn, fish of, 114.

Tyrone, fossil fish of, 118 .

ULM, sole of, 123.

Unio, 90.

United States, solipedia of, 30 ; raniceps of, 79 .

Uphill cutting, G. W. Railway, 90.

Upton on Severn, 83.

Urodeles, 98.

Ursus, 22.

Urus, 8.

VEDDAHS, rock, 6, 7.

Vicugna, 29.

Viper, 95.

Volga, sturgeon of, 108.

Vulpine phalanger, 56 .

Vulture, 55.

WADERS, 70.

Wales, glaciers of, 13 ; South, ring ouzel at, 61 ; New South, fossil fish of, 118, 120.

Walrus, 23, 86 .

Walpiti, 26.

Warwickshire, saurians of, 89 ; fossil fish of, 118.

Wart hog, 24.

"Water Babies," the, 14.

Water pig, 46.
Weald, saurians of, 90 .

Web-footed birds, 72 .

Weka rail, 71.

Whimbrel, 70 .

Wight, Isle of, footprints in, 92.

Wiltshire Downs, bustard of, 70 .

Winged lizards, 87.

Witt, Rev. Mr., 88.

Wolf, 19, 51, 104.

Wombat, 48,51 .

Wood, Lt.-Col., 25, 29, 33.

Wood, Rev. J. G., 102.

Woodcock, 70.

Woodpecker, 57, 59.

Woodthrush, 59.

Word Minnis, oriole of, 60 .

Worsaae, Professor, 8.

Worcestershire, badger of, 21 ; hippopotamus, 25 ; bos of, 27 ; teeth of, 33 ; shrike in, 60 ; labyrinthodon, 81 ; museum, 85 ; fossil fish of, 117.

Wright, Dr., 88.

Wrinkled fish, 116.

Wryneck, 57.

Wyman, Professor, 79.

Wyre Forest, shrikes of, 60 .

YarRELl's "British Fishes," 102.

York Museum, 85.

ZEAland, New, parrots of, 58 ; fossil manmal of, 49 ; notornis of, 71 ; fossil penguin of, 74 .

Zebra, 31 .

Zeuglodon, 40. 
13648 
1

i 
